Marina Blanco Cattai

\title{
Anatomia em Velloziaceae: CARACTERES, EVOLUÇÃo E FILOGENIA
}




\section{Marina Blanco Cattai}

\section{Anatomia em Velloziaceae: CARACTERES, EVOLUÇÃO E FILOGENIA}

Dissertação apresentada ao Instituto de Biociências da Universidade de São Paulo, para a obtenção do título de Mestre em Ciências, na área de Botânica

Orientação: Prof. Dr.Veronica Angyalossy 


\title{
CATtAI, M. B.
}

\author{
ANATOMIA em Velloziaceae: \\ CARACTERES, EVOLUÇÃO E FILOGENIA \\ 67 de páginas
}

Dissertação (Mestrado) - Instituto de Biociências da Universidade de São Paulo, Departamento de Botânica

I.Velloziaceae 2.Anatomia caulinar 3.Anatomia radicular 4. Xilema 5. Caracteres 6. Filogenia

\section{Comissão Julgadora}

$\operatorname{Prof}(a) \cdot \operatorname{Dr}(\mathrm{a})$.

$\operatorname{Prof}(a) \cdot \operatorname{Dr}(a)$.

Profa. Dra.Veronica Angyalossy 
"Once we have sequenced all of the relevant plant genomes and have come to realize that such sequence data leaves many questions in organismal biology, unanswered, we may finally appreciate that organisms are valid and fundamental biological units worthy of our attention. Then, morphology may finally be appreciated and respected as a key to the understanding of plant organismal biology."

DONALD R. KAPLAN American Journal of Botany 88(10): 1726. 2001. 
Dedico este trabalho às duas pessoas que tive a sorte de ter como pais 


\section{Agradecimentos}

À Fundação de Amparo à Pesquisa do Estado de São Paulo - FAPESP, pela bolsa concedida.

Aos meus queridos pais Elvira e Douglas, pela bolsa concedida.

Ao Laboratório de Anatomia Vegetal e ao Instituto de Biociências da Universidade de São Pau-

lo pela minha formação e oportunidade de desenvolver esta dissertação de mestrado.

À minha orientadora, Veronica, que sempre apoiou minhas idéias e teve muita paciência com minhas teimosias.

Ao Renato, pela co-orientação, por conhecer tanto as Velloziaceae, estar sempre disposto a me ajudar e pelas maravilhosas coletas e identificação de material.

Ao Professor João Carlos, do Anglo Vestibulares que, com suas aulas de biologia incríveis me mostrou pela primeira vez a anatomia vegetal.

À Nanuza, por ter sido minha orientadora, me mostrar a beleza da botânica e, principalmente, da anatomia e das Velloziaceae; por todo seu conhecimento e por amar tanto o que faz...

À Paula Rudall, do Royal Botanic Gardens, Kew, pelas três horas incrivelmente elucidativas em que passou olhando o meu material.

À simpática Dr.P. C. Kao por ter prontamente atendido ao meu pedido enviando amostras de Acanthochlamys bracteata e por estar sempre interessada no andamento do trabalho.

Ao Dr. Wolfran Lobin, curador do herbário de Bonn por ter me enviado amostras de Talbotia elegans.

Ao Richard, pela ajuda com as análises filogenéticas.

Ao Pirani, por ser um dos melhores professores que já tive.

À Lucia Lohmann por toda a ajuda e simpatia e pelas ótimas considerações na banca de qualificação.

À Patricinha, pelo convívio e sugestões na banca de qualificação.

Ao Greg pelas dicas metodológicas e discussões ecológicas.

Ao Tonico pelos ótimos cortes de Encholirium scrutor.

À Mamita e ao Papito, de novo, pelo apoio de sempre, em todas as minhas decisões, por terem me educado tão bem e, principalmente pelo amor de todos os dias. Eu Amo vocês!

Ao Angelo, meu Bebe Leão, por ser tão lindo, tão fofo, me aguentar esse tempo todo... Beijo na Boca!

À minha enorme família, com seu coração tão enorme quanto.Vocês fazem meus dias melhores e sem dúvida, mais engraçados.

À Tita e à Helena por terem mantido "a casa em ordem".
Às minhas inseparáveis primas: Lud, Yara, Carol, Ju, Fefa e Mari.

Aos Amelinhas, meus queridos amigos de tantos anos, sempre comigo, na alegria e na tristeza, na saúde e na doença.

Às minhas queridas amigas Lud e Maíra, por todas as nossas conversas e por estarem sempre aqui!

Ao Paulo, Poglinho querido! Por todos os anos de amizade, pelas conversas, cervejas e, é claro, por todos os ensinamentos.

À todos os meus amigos queridos do Pau-na-Máquina.

Ao Roni, por ter facilitado tanto a minha vida ao me mostrar as maravilhas do lllustrator.

Ao meu "irmão mais velho", Marccus! Por todas as nossas bebedeiras, conversas - científicas ou não - conselhos, viagens............ Ao Scott pelo incentivo e correção dos abstracts.

Às minhas queridas amigas Bia e Soffi, por todos os almoços, baladas e ombros amigos.

Ao Amauri, por todas as nossas conversas, botânicas, cladísticas, químicas, metodológicas e assuntos aleatórios.

À Gi, minha querida amiga e técnica, por todos os almoços que dividimos, pelas calorias compartilhadas e por todos os galhos que quebra no lab.

Ao Marcelo, meu querido e divertido amigo! Bi! Adoro nossas conversas e fofocas! Com você o laboratório fica muito mais alegre.

À Mariane, por todas as nossas elocubrações e por ser tão divertida.

À Erika, por todos os momentos que passamos juntas e pelo término em conjunto com tantas discusões filosóficas.

À Claudia Vecchi por sempre me lembrar das coisas importantes da vida

À Dri, Vera, Marli, Emília, Taís, Marina, Neuza, Erika, Vivi Jono, Giu, Deusa, Gui, Cris, Paula, André... companheiros de cada dia.

À Lívia, Maria Fernanda, Ju, Lia, Cris e Leandro, colegas do "lado de lá do estacionamento", pelas conversas, sistemáticas ou não.

À Suzi por manter a segunda casa em ordem.

Ao Papito, de novo, por todos os ensinamentos gráficos e pela ajuda indispensável na diagramação.

À Apple por fazer computadores tão maravilhosos, práticos, fáceis de usar e que não travam; pelo iPod, meu companheiro de microscópio. À Adobe, por ter desenvolvido o InDesign, o Illustrator e o Photoshop. Sem eles este trabaIho teria sido muito mais difícil. 


\section{Resumo}

Em Velloziaceae, a delimitação da família, subfamílias e gêneros é bastante controversa e as filogenias existentes são mal sustentadas. Considerando que os estudos anatômicos são extremamente importantes na delimitação de novas espécies, na classificação e em análises cladísticas de Velloziaceae, o presente trabalho tem como objetivo ampliar o conhecimento anatômico da raiz, do caule e da folha. Através de secções anatômicas e dissociação do xilema de vinte e cinco espécies da família e três representantes do grupo externo (Bromeliaceae, Cyclanthaceae e Pandanaceae) visa buscar novos caracteres a serem incorporados em análises cladísticas. $O$ estudo dos elementos traqueais evidenciou a presença de placa de perfuração simples na raiz e uma grande diversidade de formas de elementos traqueais no caule, já que é possível observar, em uma mesma espécie, desde traqueídes muito longas, até elementos de vaso muito curtos. À exceção de Acanthochlamys bracteata, todas as espécies analisadas possuem traqueídes no caule, característica que confere vantagens às plantas que sofrem estresses uma vez que são mais resistentes à cavitação. $\mathrm{Na}$ folha, à exceção de Talbotia elegans que possui apenas traqueídes, todas as espécies da família apresentam elementos de vaso com placa de perfuração escalariforme. $\bigcirc$ estudo dos elementos traqueais apontou quatro novos caracteres e a análise das secções transversais e longitudinais radiculares e caulinares levantou mais oito caracteres referentes à características do córtex da raiz e do caule, forma da secção transversal caulinar, presença de feixe fibroso central e feixes vasculares caulinares, a serem incorporados em análises cladísticas baseadas em dados morfológicos e combinada para a família. A hipótese filogenética obtida revelou que, dos doze caracteres analisados, seis constituem sinapomorfias de Velloziaceae incluindo Acanthochlamys bracteata, duas delas homoplásticas. Além disso, uma sinapomorfia para o clado (Nanuza Vellozia) e uma para Vellozia s.s. emergiram na análise. A hipótese filogenética obtida sustenta a inclusão de $A$. bracteata em Velloziaceae, a delimitação de Barbacenia e Vellozia proposta por Mello-Silva, e a delimitação de Smith \& Ayensu para as subfamílias de Velloziaceae s.s. 


\section{Abstract}

The classification for family, subfamilies and genera of the Velloziaceae is controversial and the existing phylogenies are poorly supported. Considering that anatomical features are widely used in the definition of new species, classification and cladistic analyses, this paper provides a better understanding of the root, stem and leaf anatomy of the Velloziaceae. Through transverse and longitudinal sections as well as xylem maceration of 25 species of Velloziaceae and three from outgroups (Bromeliaceae, Cyclanthaceae and Pandanaceae), a search of new morphological characters to be added in cladistic analyses was performed. The xylem analyses showed that all Velloziaceae have simple perforation plates in roots and a huge diversity of tracheary elements in stems including long tracheids to small vessel elements in a single species. Except for Acanthochlamys bracteata, all species present tracheids in stems, an important feature to plants that survive dry periods of several months because they can prevent cavitation. In leaves, except for Talbotia elegans that possesses only tracheids, all Velloziaceae have vessel elements with scalariform perforation plates. The analysis of tracheary elements provided four new characters. The anatomical studies produced another eight characters referring to the characteristics of the cortex of the root and stem, form of the transverse stem section, presence of a central, fibrous vascular bundle and stem vascular bundles. All of these new characters were added to morphological and combined analyses ofVelloziaceae. The cladistic analysis showed that six of the 12 characters described here are synapomorphies for Velloziaceae, including Acanthochlamys bracteata, although two are homoplastic. Furthermore, one synapomorphy of the NanuzaVellozia clade and one of Vellozia s.s. emerged in the analysis. This phylogenetic hypothesis supports the inclusion of A. bracteata in Velloziaceae, the delimitation of Barbacenia and Vellozia as proposed by Mello-Silva, and the recognition of the subfamilies of Velloziaceae s.s. as described by Smith \& Ayensu. 


\section{SUMÁRIO}

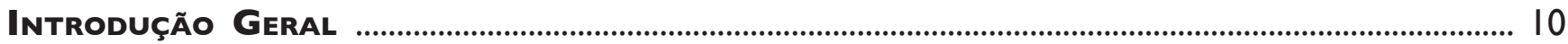

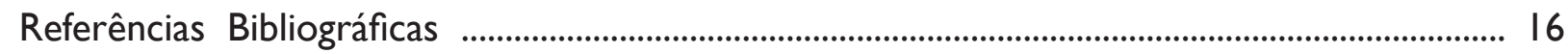

Capítulo I: Elementos traqueais em Velloziaceae ................................................................................. 19

Resumo/Abstract .................................................................................................................................. 19

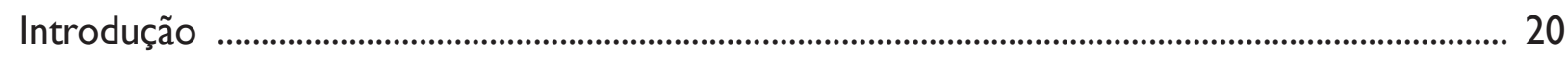

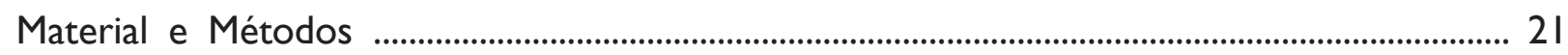

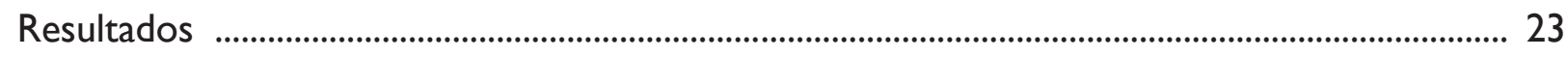

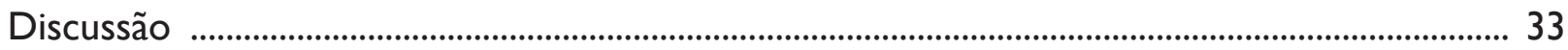

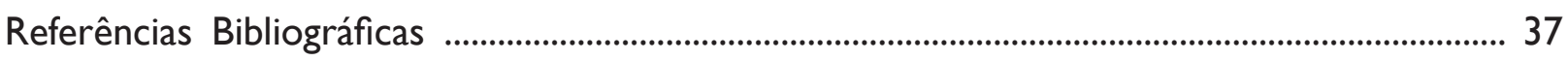

Capítulo 2: Novos caracteres anatômicos para análises filogenéticas em Velloziaceae ........... 40

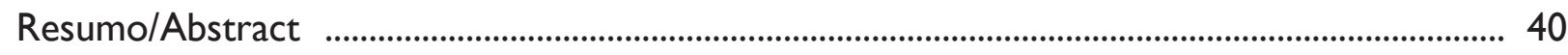

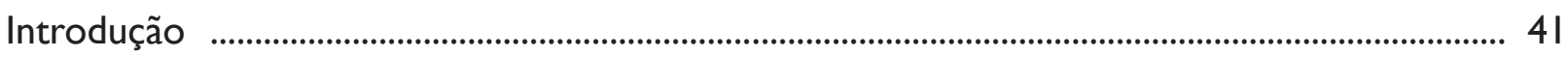

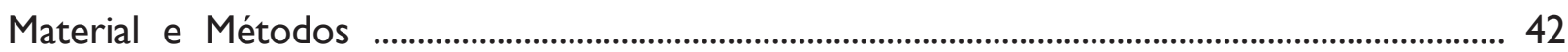

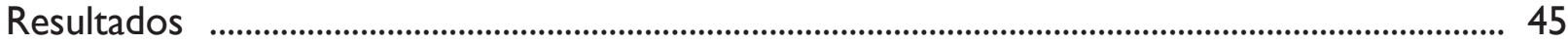

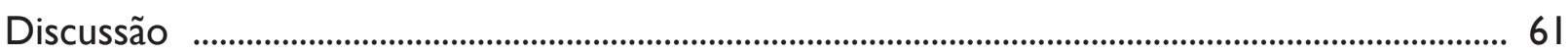

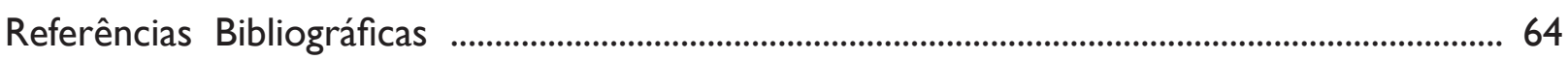

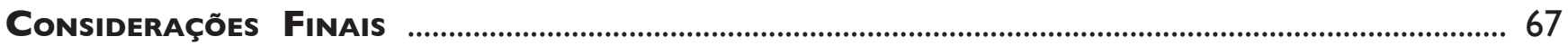




\section{Introdução Geral}

A família Velloziaceae é um grupo de monocotiledôneas essencialmente tropical com cerca de 250 espécies.A maioria ocorre na América do Sul e África (Kubitzki 1998). Muitas espécies são endêmicas e o centro de diversidade é a Cadeia do Espinhaço, no leste do Brasil central.

As afinidades de Velloziaceae com outras famílias é um tema de considerável discussão (Salatino et al. 200I) já tendo sido considerada próxima de Hypoxidaceae (Takhtajan 1969), Amaryllidaceae (Menezes 1980A), Haemodoraceae (Cronquist 1988) ou ainda Bromeliaceae (Dahlgren et al. 1985). Recentemente, Stevenson \& Loconte (1995), em análise cladística com base em dados morfológicos, novamente relacionam Velloziaceae à Hypoxidaceae e as incluem na ordem Velloziales. Chase et al. (1993, 1995), com dados de $r b c L$ e análise combinada, mostraram que o grupo irmão de Velloziaceae seria Acanthochlamys, um gênero monotípico chinês e incluiram Velloziaceae na ordem Pandanales, juntamente com Acanthochlamys, Cyclanthaceae, Pandanaceae, Stemonaceae e Triuridaceae (Figuras I-7). Todavia, Kubitzki (1998) afirma que os resultados obtidos com análises moleculares não parecem estar corroborados pelos caracteres morfológicos e, quando muito, sustentam um forte isolamento de Velloziaceae. Trabalhos recentes com análises moleculares (Davis et al. 2004, Chase et al. 2006) e morfológicos (Rudall \& Bateman 2006) demonstram que Velloziaceae é o grupo basal das Pandanales e Acanthochlamys bracteata a espécie que primeiro divergiu na ordem.
Vandelli (1788) foi o primeiro a descrever espécies da família, a partir de exemplares brasileiros e reconheceu dois gêneros, Vellozia, com I5 estames e estigma capitado, e Barbacenia, com seis estames e estigma oval-acuminado. Um ano depois, Jussieu (I789) descreveu o gênero Xerophyta baseado em espécie de Madagascar com seis estames e estigma oblongo. Martius ( 1823 ) ampliou a delimitação de Vellozia, incluindo espécies com seis estames, mas Schultes \& Schultes $f$. (I829) e Sprengel ( I827) transferem todas as espécies de Vellozia com seis estames para o gênero Xerophyta.

Baker (1875) valorizando novamente apenas o caráter número de estames, considerou as espécies brasileiras de Vellozia com seis estames como pertencentes ao gênero Xerophyta e, em I898, considerando exclusivamente o comprimento do hipanto sobre o ovário, transferiu todas as espécies africanas para Vellozia. Bentham \& Hooker (1883) tratam Vellozia e Barbacenia como pertencentes à tribo Vellosieae da família Amarylidaceae baseando-se no comprimento do hipanto para distinguir os gêneros.

Pax (I888) volta a enfatizar o número de estames e divide a família nos gêneros originais: Vellozia com mais de seis estames e Barbacenia com seis estames, subdividido na seção Xerophyta com filetes lineares e na seção Barbacenia com filetes aplanados. Baillon (I895) reuniu todas as espécies de Velloziaceae no gênero Barbacenia, dividindo-o em quatro seções (Barbacenia, Radia, Vellozia, Xerophyta) distintas pelo comprimento do hipanto e número de estames. 

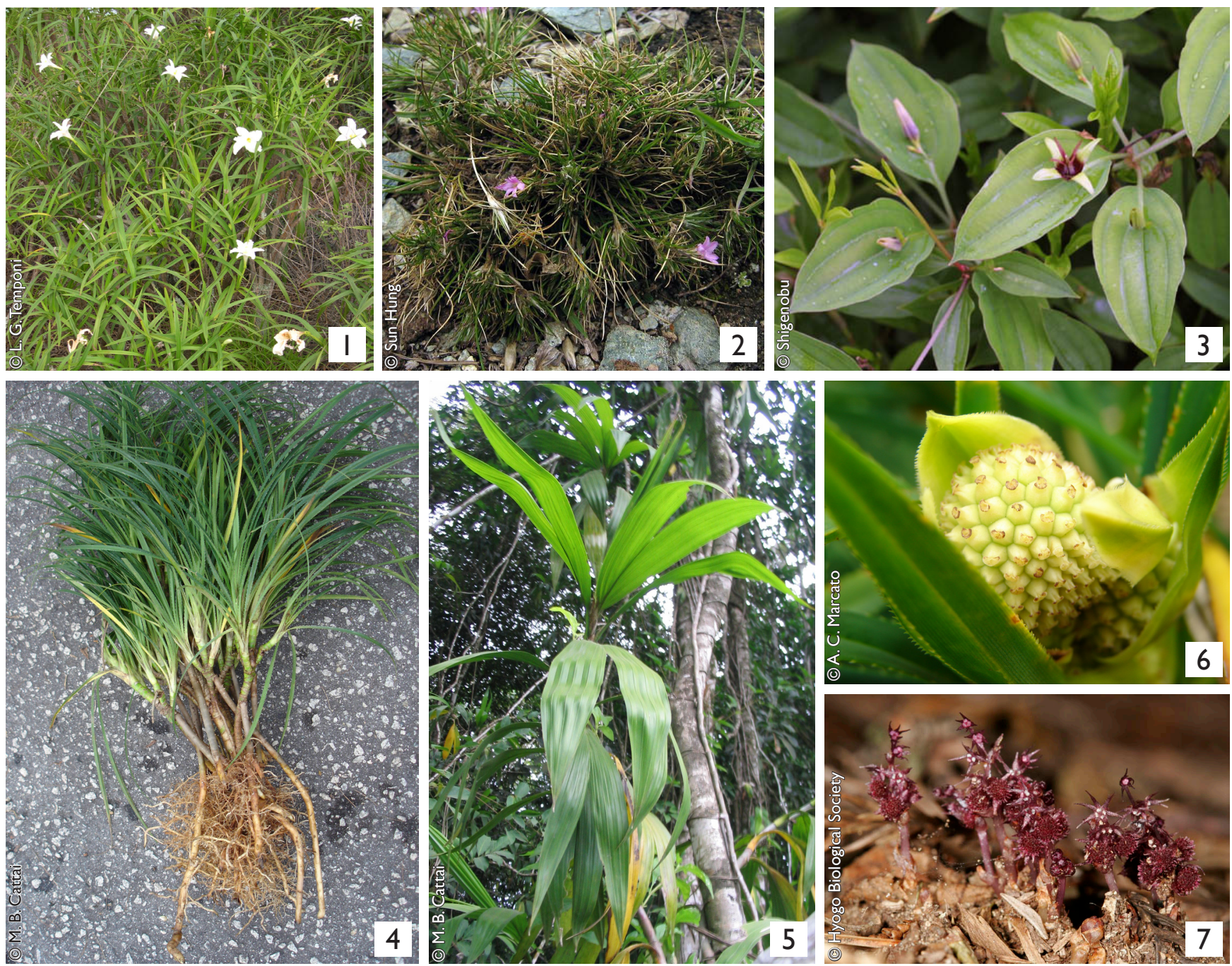

Figuras I a 7: Espécies representantes das famílias da ordem Pandanales: I: Vellozia candida (Velloziaceae), 2: Acanthochlamys bracteata, 3: Stemona japonica (Stemonaceae), 4: Pandanus racemosus (Pandanaceae), 5: Thoracocarpus bissectus (Cyclanthaceae), 6: Detalhe da inflorescencia de Pandanus racemosus, 7: Sciaphila tosaensis (Triuridaceae)

Perrier $(1930,1946)$ restabeleceu o gênero Xerophyta para as espécies de Madagascar e reconheceu Vellozia e Barbacenia segundo a delimitação de Vandelli (1788) levando em conta características do hipanto, número de estames e formato dos estigmas. Seubert (1847) faz a primeira revisão para Velloziaceae reconhecendo dois gêneros: Barbacenia e Vellozia, sendo que este último permanece com a ampla delimitação proposta por Martius ( 1823$)$.

A moderna taxonomia da família iniciou-se com a revisão de Smith (1962), que reconheceu três gêneros, Vellozia, Barbaceniopsis e Barbacenia, baseando-se em caracteres morfológicos florais. Menezes ( 197 IA) por sua vez, dividiu a família em duas subfamílias, Vellozioideae e Barbacenioideae, baseando-se na presença e ausência de corona e no número de camadas de células na bainha do feixe foliar e restabelece - gênero Xerophyta. Assim, a subfamília Vellozioideae sensu Menezes compreende os gêneros Vellozia e Xerophyta, enquanto que Barbacenia e Aylthonia (Menezes I97IA) compõem as Barbacenioideae. 
Smith \& Ayensu (1976) reconhecem as subfamílias criadas por Menezes (I 97 IA) porém, modificando-as quase completamente. Estes autores descrevem o gênero Nanuza e o incluem, juntamente com Vellozia na subfamília Vellozioideae. Reconhecem ainda Barbacenia, Barbaceniopsis, Talbotia (Balf I868) e Xerophyta incluídos em Barbacenioideae.

Menezes reavaliou sua classificação em I980A e delimitou novos gêneros para suas subfamílias. Vellozioideae permaneceu com os gêneros Vellozia e Xerophyta, enquanto que, em Barbacenioideae, a autora incluiu Barbacenia, Aylthonia, Burlemarxia (Menezes \& Semir 199I) e Pleurostima (restabelecido por Menezes 1980B), sendo os três últimos segregados de Barbacenia. Os gêneros Barbaceniopsis, Talbotia e Nanuza não foram aceitos por Menezes (1980A) e suas espécies foram incluídas em Xerophyta, juntamente com outras espécies de Vellozia, sensu Smith \& Ayensu (1976), da América do Sul.

A grande diferença entre os dois sistemas de classificação propostos para Velloziaceae é que Menezes priorizou a presença ou ausência de corona e a constituição das bainhas dos feixes em sua classificação e Smith \& Ayensu deram prioridade à morfologia do estigma e filete e para a posição dos apêndices florais em relação aos filetes (Mello-Silva I99/A).Ambas as classificações são intransigentes na escolha de caracteres enfatizados e na tentativa de classificar espécies do Novo Mundo nos gêneros do Velho Mundo e vice-versa (Mello-Silva I99/B).

Foram descritos nove gêneros de Velloziace- ae (figuras 8 a 16): Aylthonia, Barbacenia, Barbaceniopsis, Burlemarxia, Nanuza, Pleurostima, Talbotia, Vellozia e Xerophyta, ainda que este número seja bastante controverso (Kubitzki 1998).

No que diz respeito à classificação infragenérica, também há divergências na literatura. Em Vellozia Smith \& Ayensu (1976) reconhecem três seções, Vellozia, Radia e Xerophytoides, baseadas no comprimento do hipanto e na forma da lâmina foliar, e Menezes (I980A) reconhece duas seções, Vellozia e Radia, baseadas no comprimento do hipanto. Menezes (I980A) considera que as espécies incluídas na seção Xerophytoides, todas com seis estames, pertencem ao gênero Xerophyta. único ponto comum entre as classificações é a seção Radia de Vellozia. Mello-Silva (I99/B) reconhece a delimitação do gênero Vellozia de Smith \& Ayensu (1976), redelimita a seção Xerophytoides, incluindo uma nova espécie com 12 estames e, em 2000, sinonimiza a seção Radia em Vellozia.

Segundo Salatino et al. (1989), o estudo dos alcanos epicuticulares das folhas de Velloziaceae apóia a existência de duas subfamílias. Além disso, no primeiro trabalho de cladísitica com a família (Menezes et al. 1994), os autores apontam que a subfamília Barbacenioideae, sensu Menezes (I980A) é monofilética e melhor sustentada que Barbacenioideae sensu Smith \& Ayensu (1976). O monofiletismo de Barbacenioideae sensu Menezes (I980A) também foi corroborado em trabalho utilizando dados macromoleculares (Salatino et al. 200I). Já Melo et al. (1997) em estudo citogenético verificaram que as espécies de Barbacenioideae 

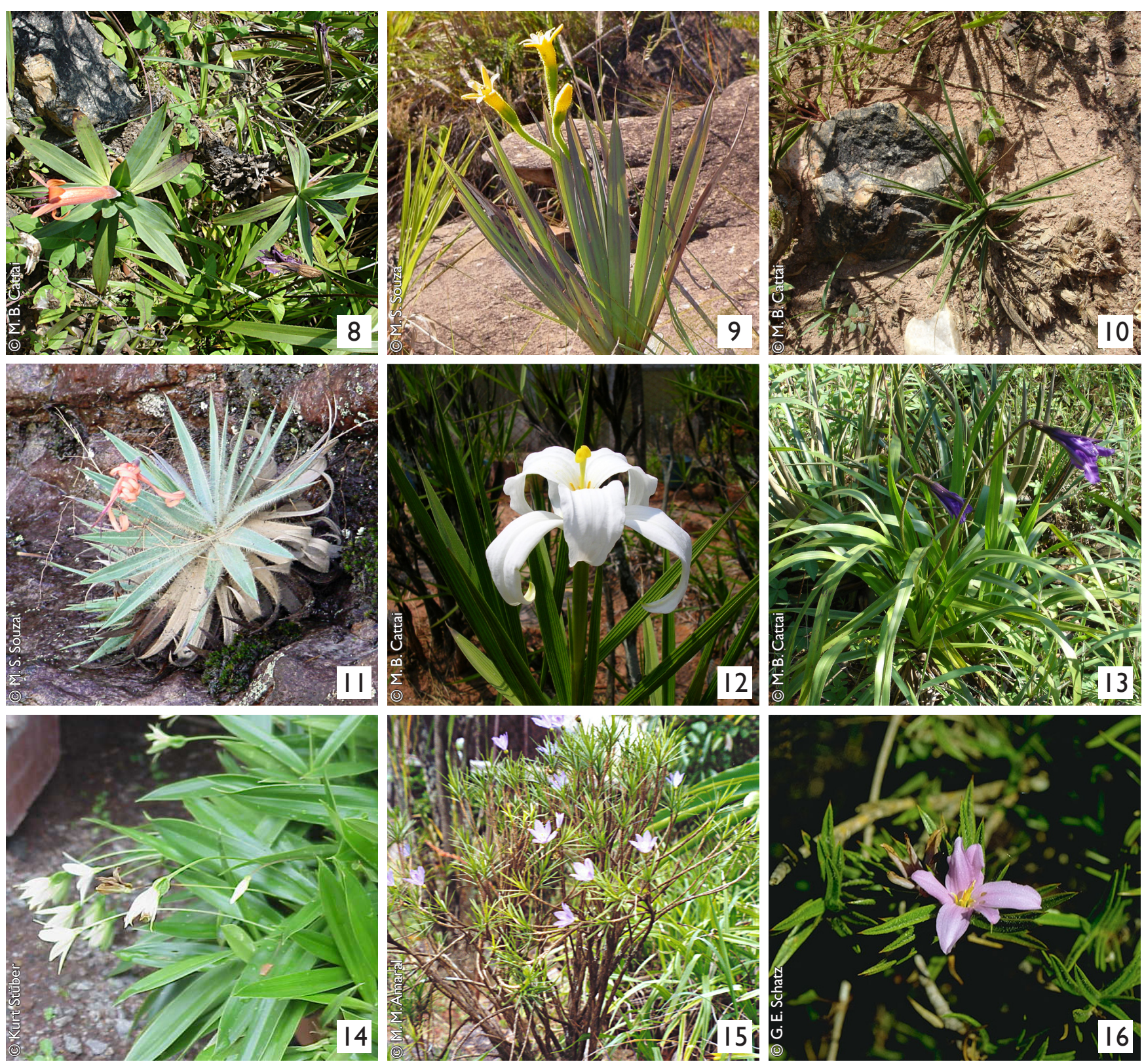

Figuras 8 a 16: Gêneros descritos para Velloziaceae. 8: Aylthonia sp. 9: Barbacenia flava I 0: Barbaceniopsis sp. I I: Burlemarxia pungens I 2: Nanuza plicata I3: Pleurostima purpurea I4: Talbotia elegans I5: Vellozia epidendroides I6: Xerophyta pinifolia.

sensu Menezes possuem um número de cromossomos exclusivo. A subfamília Vellozioideae sensu Menezes mostrou-se parafilética, tanto no trabalho de Menezes et al. (1994) quanto no de Salatino et al. (200I). Williams (199I) por sua vez, utilizando flavonóides foliares, observou que apenas espécies da subfamília Vellozioideae sensu Menezes (I980A) possuem flavo- na mono-C-glicosídeos, única característica presente apenas nos gêneros desta subfamília. Já as subfamílias como foram circunscritas por Smith \& Ayensu (1974, 1976) são parafiléticas em todas as análises cladísticas já realizadas com a família (Menzes et al. 1994, MelloSilva 2000, Behnke et al. 2000, Salatino et al. 200I, Mello-Silva 2005). 
A delimitação dos gêneros, bastante controversa na história da família, foi discutida com base na sistemática filogenética por Mello-Silva (2005) que apresenta análise cladística baseada em dados morfológicos, anatômicos e químicos com 47 espécies da família. Neste trabalho, Aylthonia emergiu monofilético, Barbaceniopsis mono ou parafilético e Pleurostima parafilético. $O$ autor, baseado no monofiletismo dos grupos, optou por reconhecer somente os gêneros Barbacenia (incluindo espécies pertencentes aos gêneros Aylthonia, Burlemarxia e Pleurostima), Talbotia, Vellozia (incluindo a única espécie do gênero Nanuza) e Xerophyta (incluindo as espécies pertencentes a Barbaceniopsis). Nesta análise, Acanthochlamys também aparece como grupo irmão de Velloziaceae e, por ser monotípico, foi incluído na família que fica, assim, composta por cinco gêneros. Nesta mesma análise, a subfamília Barbacenioideae sensu Menezes emerge monofilética mas Vellozioideae permanece parafilética, assim como as seções estabelecidas para o gênero Vellozia. Apesar desta proposta de classificação, a filogenia e, conseqüentemente a classificação das Velloziaceae não estão ainda bem definidas (Mello-Silva 2006). O complexo histórico da classificação da família encontra-se resumido na tabela I.

Os estudos anatômicos em Velloziaceae iniciaram-se com Warming (1893) e se intensificaram a partir de Ayensu (1968), que descreveu a anatomia da raiz, caule e folha de duas espécies de Barbaceniopsis. $\mathrm{O}$ autor realizou outros estudos com anatomia foliar de diversas espécies de Velloziaceae, sendo os primeiros trabalhos (1969A, 1969B) referentes à anatomia foliar das espécies africanas e o terceiro, e mais extnso (1974), à anatomia foliar das espécies americanas. Menezes (197/B) estudou a ontogenia do caule de quatro espécies de Vellozia, no intuito de avaliar a saída dos traços foliares e constatou que nestes, assim como nos feixes foliares, ocorre a presença de traqueídes de transfusão. Menezes (1975) constatou a presença destas mesmas traqueídes nas foIhas de espécies de Barbacenioideae.

A anatomia foliar foi extensamente utilizada por diversos autores na descrição de novas espécies (e.g. Menezes \& Semir I99I, Mello-Silva 199IB, MelloSilva \& Menezes 1988, 1999, McPherson et al. 1997, Alves 2002), e foi utilizada com grande importância nas análises cladísticas (Menezes et al., 1994, Mello-Silva 2000, 2005). Mello-Silva $(2000,2005)$ aponta diversas características da anatomia foliar úteis para a análise cladística como por exemplo, tipos de estômatos, distribuição estomática, células subsidiárias, células especializadas na face adaxial da folha (células epidérmicas com maior diâmetro em relação às demais), organização do parênquima aqüífero, presença de vasos na folha e reentrâncias na lâmina foliar. $\mathrm{A}$ anatomia do pedicelo também foi utilizada por Mello-Silva (2000, 2005) com o uso de caracteres como a forma da secção transversal do pedicelo, o número de feixes vasculares e a presença de células esclerificadas.

Considerando que os estudos anatômicos são extremamente importantes para a caracterização da família e em análises cladísticas, o presente trabalho tem como objetivo ampliar o conhecimento anatômico da raiz e do caule através de secções anatômicas e dissociação do xilema. Assim, será possível avaliar novos 
Tabela I: Resumo do histórico das classificações de Velloziaceae

\begin{tabular}{|c|c|}
\hline Autor & ClassificaÇÃo \\
\hline Vandelli (I 788) & $\begin{array}{l}\text { Barbacenia: } 6 \text { estames, estigma oval-acuminado } \\
\text { Vellozia: I } 5 \text { estames estigma capitado }\end{array}$ \\
\hline Jussieu (I789) & $\begin{array}{l}\text { Xerophyta: } 6 \text { estames, estigma oblongo e } \\
\text { cálice tubuloso }\end{array}$ \\
\hline Martius 1823 & $\begin{array}{l}\text { Barbacenia: } 6 \text { estames e anteras dorsifixas } \\
\text { Vellozia: } 6 \text { e } 15 \text { estames a anteras basifixas }\end{array}$ \\
\hline $\begin{array}{l}\text { Shultes (1829) e } \\
\text { Sprengel (1827) }\end{array}$ & $\begin{array}{l}\text { Xerophyta: incluem no gênero todas as espé- } \\
\text { cies com seis estames }\end{array}$ \\
\hline Baker (1875) & $\begin{array}{l}\text { Xerophyta: transfere as espécies brasileiras } \\
\text { de Vellozia com } 6 \text { estames para o gênero }\end{array}$ \\
\hline Baker (1898) & $\begin{array}{l}\text { Vellozia: transfere espécies africanas para o } \\
\text { gênero valorizando o comprimento do hipanto }\end{array}$ \\
\hline $\begin{array}{l}\text { Bentham \& } \\
\text { Hooker (I 883) }\end{array}$ & $\begin{array}{l}\text { Transferem Velloziaceae para a tribo Vellozie de } \\
\text { Amaryllidaceae baseando-se no comprimento } \\
\text { do hipanto para distinguir Barbacenia e Vellozia }\end{array}$ \\
\hline $\operatorname{Pax}(1888)$ & $\begin{array}{l}\text { Barbacenia: } 6 \text { estames - seção Xerophyta: filetes } \\
\text { lineares, seção Barbacenia: filetes aplanados. } \\
\text { Vellozia: mais de } 6 \text { estames }\end{array}$ \\
\hline Bailon (1895) & $\begin{array}{l}\text { Barbacenia: abrange todas as espécies da famí- } \\
\text { lia. } 4 \text { seções: Barbacenia, Radia, Vellozia e Xero- } \\
\text { phyta distintas pelo comprimento do hipanto }\end{array}$ \\
\hline Balf I868 & $\begin{array}{l}\text { Descreve o gênero Talbotia para Amaryllida- } \\
\text { ceae }\end{array}$ \\
\hline $\begin{array}{l}\text { Perrier } \\
(1930,1946)\end{array}$ & $\begin{array}{l}\text { Barbacenia: } 6 \text { estames, estigma oval-acuminado } \\
\text { Vellozia: I } 5 \text { estames e estigma capitado } \\
\text { Xerophyta: espécies de Madagascar }\end{array}$ \\
\hline Seubert (1947) & $\begin{array}{l}\text { Barbacenia: } 6 \text { estames, estigma oval-acuminado } \\
\text { Vellozia: I } 5 \text { e } 6 \text { estames }\end{array}$ \\
\hline Smith (1962) & $\begin{array}{l}\text { Barbacenia: anteras dorsifixas, filete achatado } \\
\text { Barbaceniopsis: descreve o gênero que possui } \\
\text { anteras dorsifixas com filete cilíndrico } \\
\text { Vellozia: anteras basifixas }\end{array}$ \\
\hline
\end{tabular}

caracteres para a utilização em análises cladísticas, bem como analisar essas características em Acanthochlamys bracteata e em duas espécies da ordem Pandanales, representantes do grupo externo. Paralelamente, este estudo possibilitará a avaliação da evolução destes caracteres nas filogenias já existentes da família e da ordem.

\begin{tabular}{|c|c|}
\hline Autor & Classificação \\
\hline Menezes (197IA) & $\begin{array}{l}\text { Aylthonia: Barbacenioideae } \\
\text { Barbacenia: Barbacenioideae } \\
\text { Vellozia: Vellozioideae } \\
\text { Xerophyta: Redelimita o gênero incluindo es- } \\
\text { pécies brasileiras, pertence à Vellozioideae }\end{array}$ \\
\hline $\begin{array}{l}\text { Smith \& Ayensu } \\
(1974,1976)\end{array}$ & $\begin{array}{l}\text { Barbacenia: Barbacenioideae } \\
\text { Barbaceniopsis: Barbacenioideae } \\
\text { Nanuza: Descrevem o gênero e o incluem } \\
\text { em Vellozioideae } \\
\text { Talbotia: Barbacenioideae } \\
\text { Vellozia:Vellozioideae. } 3 \text { seções: Vellozia, Radia } \\
\text { e Xerophytoides } \\
\text { Xerophyta: Barbacenioideae. } 3 \text { seções: Xero- } \\
\text { phyta, Vellozioides e Barbacenioides }\end{array}$ \\
\hline $\begin{array}{l}\text { Menezes (1980A, } \\
\text { 1980B, 199I) }\end{array}$ & $\begin{array}{l}\text { Aylthonia: Barbacenioideae } \\
\text { Barbacenia: Barbacenioideae } \\
\text { Barbaceniopsis: Xerophyta sect. Xerophyta } \\
\text { Burlemarxia: descreve o gênero, único de Bar- } \\
\text { bacenioideae cujas anteras não são sésseis } \\
\text { Nanuza: Xerophyta sect. Talbotia } \\
\text { Pleurostima: reestabelece o gênero. } 2 \text { seções: } \\
\text { Pleurostima e Graziela - Barbacenioideae } \\
\text { Talbotia: Xerophyta sect. Talbotia } \\
\text { Vellozia:Velloziaoideae. } 2 \text { seções: Vellozia e Radia. } \\
\text { Xerophyta:Vellozioideae. } 2 \text { seções: Xerophyta } \\
\text { e Talbotia }\end{array}$ \\
\hline $\begin{array}{l}\text { Mello-Silva } \\
(2005)\end{array}$ & $\begin{array}{l}\text { Acanthochlamys: inclui o gênero na família } \\
\text { Barbacenia: inclui espécies de Aylthonia, Bar- } \\
\text { bacenia, Burlemarxia e Pleurostima } \\
\text { Talbotia:Aceita o gênero } \\
\text { Vellozia: Inclui Nanuza e Vellozia sensu Smith } \\
\text { \& Ayensu } \\
\text { Xerophyta: inclui espécies de Xerophyta sensu } \\
\text { Smith \& Ayensu e Barbaceniopsis }\end{array}$ \\
\hline
\end{tabular}

Este trabalho enfoca os órgãos vegetativos de vinte e cinco espécies de Velloziaceae e três espécies representantes do grupo externo e está dividido em dois capítulos que abordam os elementos traqueais e novos caracteres anatômicos para utilização em análises cladísticas. 


\section{Referências Bibliográficas}

Alves, R.J.V. 2002. Two new species of Nanuza (Velloziaceae) from Brazil. Novon 12: 12-17.

Ayensu, E. S. 1968. The anatomy of Barbaceniopsis, a new genus recently described in the Velloziaceae. American Journal of Botany 55: 399-405.

Ayensu, E. S. 1969A. Leaf-anatomy and systematics of Old World Velloziaceae. Kew Bulletin 23: 315-335.

AyENSU, E. S. 1969B. The identity of Vellozia uiapanensis. Anatomical evidence. Memoirs of the New York Botanical Garden 18: 291-298.

AYENSU, E. S. 1974. Leaf anatomy and systematics of the new world Velloziaceae. Smithsonian Contributions to Botany I5: I- 125 .

Baillon, H. E. I895. Histoire des plantes. Vol.3. Hachette et Cie, Paris.

BAKER, J. G. I875. Journal of Botany I 3: 23 I-236.

BAKER, J. G. I 898.Amaryllidaceae in:Thiselton-Dyer,W.T. Flora of Tropical Africa. Lovell Reeve \& Co. London.

BALF, J. H. I868. Amaryllidaceae: Talbotia. Trans. Bot. Soc. Edinb 9: 192.

Behnke, H.-D., Treutlenin, J., Wink, M., Kramer, K., Schneider, C. \& KAO, P. C. 2000. Systematics and evolution of Velloziaceae, with special reference to sieve-element plastids and rbcL sequence data. Botanical journal of the Linnean Society I3493-I29.

Bentham, G., Hooker, J. D. I883. Amaryllidaceae. In: Genera Plantarum 3(2). L. Reeve \& Co., London, 739-740.

Chase, M.W., Soltis, D. E., Olmstead, R. G., Morgan, D., Les, D. H., Mishler, B. D., Duvall, M. R., Price, R. A. Hills, H. G., QIu,Y.-L., Kron, K.A., Rettig, J. D., Manhart, J. R., Sytsma, K. J., Michaels, H. J., Kress, W. J., Karol, K. G., Clark, W. D., Hedrén, M., Gau, B. S., Jansen, R. K., Kim, K.-J.,Wimpee,
C. F., Smith, J. F., Furnier, G. R., Strauss, S. H., Xiang, Q.Y., Plunkett, G. M., Soltis, P. S., Swensen, S. M., Williams, S. E., Gadek, P. A., Quinn, C. J., Eguiarte, L. E., Golenberg, E., Learn Jr., G. H., Graham, S. W., Barrett, S. C. H., Dayanandan, S., Albert, V.A. 1993. Phylogenetics of seed plants: an analysis of nucleotide sequences from the plastid gene rbcL.Annals of the Missouri Botanical Garden 80: 529-580.

Chase, M. W., Stevenson, D. W., Wilkin, P., Rudall, P. J. 1995. Monocot systematics: a combined analysis. In: Monocotyledons: systematic and evolution (P. J. Rudall, Cribb, P.J., Cutler, D. F., Humphries, C.J., ed). Royal Botanic Gardens, Kew, p. 685-730.

Chase, M. W., Fay, M. F., Devey, D. S., Maurin, O., Rønsted, N., Davies, J., Pillon, Y., Petersen, G., Seberg, O., Tamura, M. N., Asmussen, C. B., Hilu, K., Borsch, T., Davis, J. I., Stevenson, D.W., Pires, C., Givnish, T. J., Sytsma, K. J., McPherson, M. M., Graham, S.W., Ral, H. S. 2006. Multigene analyses of monocots relationships: a summary. In: (Eds.) J. T. Columbus, E. A. Friar, J. M. Porter, L. M. Prince, M. G. Simpson. Monocots: comparative biology and evolution. Claremond California: Rancho Santa Ana Botanic Garden. Aliso (I): 62-74.

CRONQUist, A. 1988. The evolution and classification of flowering plants. New York Botanical Garden, New York.

Dahlgren, R. M., Clifford, H.T.,Yeo, P.E. 1985. The families of the monocotyledons. Springer-Verlag, Berlin.

Davis, J. I., Stevenson, D.W., Petersen, G., Seberg, O., Campbell, L. M., Freudenstein, J.V., Goldman, D. H., Hardy, C. R., MIChelangeli, F.A., Simmons, M. P., SpeCht, C. D., Vergara-SilVA, F., GANDOLFO, M. 2004.A phylogeny of the monocots inferred from $r b c L$ and atpA sequence variation, and a comparison of methods for calculating jackknife and bootstrap values. Systematic Botany 29 (3): 467-5I 0.

JusSIEU,A. L., I 789. Genera plantarum. Herrisant \& Barrois Paris. 
KUBITZKı, J. G. 1998. Velloziaceae. In: Kubitzki, J. G., Huber, H., Rudall, P.J., Stevens, P. S., Stützel (eds.).The Families and Genera of Vascular Plants. III. Flowering plants - Monocotyledons. Lilianae (except Orchidaceae), 459-467. Springer-Verlag, Berlin.

Martius, C. F. P. 1823. Nova Genera et species plantarum brasiliensium Vol. I, Wolf, München.

Mcpherson, G.,Van Der Werff, H., Keating, R. C. 1997.A new species of Xerophyta (Velloziaceae) from Madagascar. Novon 7: 387-394.

Mello-Silva, R. 199IA. A new species of Vellozia from the Espinhaço Range Brazil, with some considerations on the section Xerophytoides. Kew Bulletin 46: 32 1-326.

Mello-Silva, R. 199/B. The infra-familial taxonomy circumscription of the Velloziaceae. A historical and critical analysis. Taxon 40: 45-5I.

Mello-Silva, R. 2000. Partial cladistic analysis of Vellozia and characters for the phylogeny of Velloziaceae. in: K. L. Wilson, Morrison, D. A. [eds.], Monocots systematic and evolution, 505-522. CSIRO, Melbourne.

Mello-Silva, R. 2005. Morphological analysis, phylogenies and classification in Velloziaceae. Botanical Journal of the Linnean Society I48: I57-I73.

Mello-Silva, R. 2006. Roxo é Velloziaceae: uma história natural em construção. Tese de Livre-Docência. Universidade de São Paulo. São Paulo.

Mello-Silva, R., Menezes, N. L. 1988. Duas espécies novas de Velloziaceae de Minas Gerais. Acta Botanica Brasilica I (supl.): 195-207.

Mello-Silva, R., Menezes, N. L. 1999. Two new brazilian Velloziaceae, Vellozia auriculata and Vellozia gigantea, and a key to the related dracenoid species of Vellozia. Novon 9: 536-54I.

Melo, N. F., Guerra, M., Benko-Iseppon, A. M., Menezes, N. L. 1997. Cytogenetics and cytotaxonomy of Velloziaceae.
Plant Systematics and Evolution 204: 257-273.

Menezes, N. L. 197IA. New taxa and new combinations in Velloziaceae. Ciência e Cultura 23: 421-422.

Menezes, N. L. 197|B. Traqueídes de transfusão no gênero Vellozia Vand. Ciência e Cultura 23: 389-409.

Menezes, N. L. 1975. Presença de traqueídes de transfusão e bainha mestomática em Barbacenioideae (Velloziaceae). Boletim de Botânica da Universidade de São Paulo 3: 29-60.

Menezes, N. L. 1980A. Evolution in Velloziaceae, with special reference to androecial characters. In: Brickell C.D., Cutler D.F. \& Gregory M. (eds.), Petaloid monocotyledons: Horticultural and botanical research. I I7-I39. Academic Press. London.

Menezes, N. L. 1980B. Re-establishment of genus Pleurostima Rafinesque (Velloziaceae). Revista Brasileira de Botânica 3: 37-47.

Menezes, N. L., SemiR, J. 199I. Burlemarxia, a new genus of Velloziaceae. Taxon 40: 4I3-426.

Menezes, N. L., Mello-Silva, R., Mayo, S. J. 1994. A cladistic analysis of the Velloziaceae. Kew Bulletin 49: 7I-92.

PAX, F. 1888. Velloziaceae in: Engler, A., Prantl, K. Die Natürlichen Pflanzefamilien 2(5): I25-I 27.

Perrier, H. 1930. Les Xerophyta de Madagascar. Archives de Botanique 4(6): 65-75.

Perrier, H. 1946.Au sujet de la systematique des Vellosiacées et du genre Xerophyta Juss. Notulae Systematique I2: |46-| 48 .

Rudall, P.J., Bateman, R. M. 2006. Morphological phylogenetic analysis of Pandanales: testing contrasting hypotesis of flora evolution. Systematic Botany 3 I (2): 223-238.

Salatino, M. L. F., Salatino, A., Menezes, N. L., Mello-Silva, R. 1989. Alkanes of foliar epicuticular waxes of Velloziaceae. Phytochemistry 28: I I05- I | |4. 
Salatino,A., Salatino, M. L. F., Mello-Silva, R., Sluys, M.A. 200 I.

Phylogenetic inference in Velloziaceae using cloroplast trnL-F sequences. Systematic Botany 26: 92-103.

SCHultes, J.A., SChulteS, J.H. 1829. Barbacenia, Xerophyta, Vellozia. In: Roemer, J.J. \& Schultes, J.A. (eds.), Systema vegetabilium.Vol. 7(I). 284 - 293 J.G. Cottae. Stuttgart.

SeuberT, M. 1847. Vellosieae. In: Martius C.F.P. (ed.), Flora brasiliensis. Vol. 3(I): 65-84, t. 8-I0. Fridrich Fleischer. Leipzig.

SMITH, L. B. 1962. A synopsis of the American Velloziaceae. Contributions from the United States National Herbarium 35:25I-292.

SMith, L. B., Ayensu, E. S. 1974. Classification of old world Velloziaceae. Kew Bulletin 29 (I): 18I-205.

SMITH, L. B.,Ayensu, E. S. 1976.A revision of American Velloziaceae. Smithsonian Contributions to Botany 50:1-172.

SPRENGEL, K. 1827. Systema vegetabilium.Vol. 4(2). Göttingen:
Dieterich.

Stevenson, D. W. \& Loconte, H. 1995. Cladistic analysis of monocot families. in: Monocotyledons: systematics and evolution (P.J. Rudall, Cribb, P.J., Cutler, D. F., Humphries, C. J., ed). Royal Botanic Gardens, Kew, London, p. 543-578.

TAKHTAJAN, A. 1969. Flowering plants, origin and dispersal. Oliver \& Boyd, Edinburg.

VANDELLI, D. I 788. Florae lusitanicae et brasiliensis specimen. Typografia Academico-Regia. Coimbra.

WARMING, E. 1893. Note sur la biologie et l'anatomie de la feuille des Velloziacées. Overs. K. DanskeVidensk. Selsck Forh.:57-100.

Williams, C.A., Harborne, J. B., Menezes, N. L. 199I.The utility of leaf flavonoids as taxonomy markers in the subfamily and generic classification of the Velloziaceae. Biochemical Systematics and Ecology 19: 483-495. 


\title{
Capítulo I: \\ Elementos traqueais em Velloziaceae
}

\author{
Marina Blanco Cattai, Renato de Mello-Silva \& Veronica Angyalossy
}

\section{Resumo}

A primeira teoria gradista que tentava explicar tendências evolutivas no xilema predizia que os elementos de vaso das angiospermas surgiram a partir de traqueídes e os das monocotileôneas evoluíram da raiz para a folha sendo que, entre as espécies em que ocorre uma ampla variação nos tipos de elementos de vaso de órgão para órgão, os vasos da raiz são sempre os mais especializados. Abordagens mais recentes com a utilização de caracteres anatômicos do xilema à luz da sistemática filogenética demonstraram que elementos de vaso foram perdidos diversas vezes nas angiospermas. Dentre as monocotiledôneas, caracteres do xilema não são utilizados em análises cladísticas. Este estudo teve como objetivos avaliar, através de macerações e secções transversais e longitudinais, a diversidade dos elementos traqueais nos diferentes órgãos vegetativos de Velloziaceae e verificar possíveis características filogeneticamente informativas. Através da análise de 25 espécies da família e três representantes do grupo externo, observou-se que as Velloziaceae possuem elementos de vaso com placa de perfuração simples na raiz, o que pode constituir uma sinapomorfia do grupo já que apenas uma espécie do grupo externo possui elementos de vaso na raiz, com placa de perfuração escalariforme. Já a análise dos elementos traqueais caulinares mostrou uma grande diversidade de formas, podendo apresentar, em uma mesma espécie, desde traqueídes muito longas, até elementos de vaso muito curtos. À exceção de Acanthochlamys bracteata, todas as espécies da família possuem traqueídes no caule como principal elemento condutor. Uma vez que todas as espécies de Velloziaceae são revivecentes e habitam locais onde estão expostas à estresses hídricos, a presença de traqueídes pode estar relacionada ao fato de que este tipo de elemento traqueal é mais resistentes à cavitação. Na folha, à exceção de Talbotia elegans e das espécies do grupo externo, todas as espécies analisadas apresentam elementos de vaso com placa de perfuração escalariforme, que também previne a ocorrência de cavitação. Assim, algumas características dos elementos traqueais dos órgãos vegetativos de Velloziaceae podem constituir caracteres informativos em análises cladísticas e se mostraram adaptadas às condições do ambiente que estas plantas ocupam.

Palavras-Chave: Velloziaceae, xilema, estresse hídrico, sistemática filogenética.

\section{Abstract}

The first gradist theory that tried to explain trends in xylem evolution states that angiosperm vessel elements evolved from tracheids, in monocots they evolved from the root to the leaf, and in species that have a wide variety of vessel elements, the root ones are always the most specialized. Recent cladistic analyses showed that in the angiosperms, vessel elements were lost many times, but in monocots, these features are not used in phylogenetic analyses. This study aims to explore the diversity of the Velloziaceae tracheary elements in the vegetative organs and verify possible useful characters for future cladistic analyses. The analysis of 25 Velloziaceae and three outgroup species showed that all the Velloziaceae have vessel elements with simple perforation plates in roots, a feature that constitutes a synapomorphy for the family since the only outgroup species that have vessel elements in roots, also have scalariform perforation plates. The stem tracheary elements are very diverse and one can observe very long tracheids to very small vessel elements in the same species. Except for Acanthochlamys bracteata, all Velloziaceae have tracheids in the stem as the main conductor element. All Velloziaceae are desiccation-tolerant and can survive dry periods of several months, and the presence of tracheids in the stem might increase resistance to cavitation.Apart from Talbotia elegans, all Velloziaceae have vessel elements with scalariform perforation plates in leaves, a feature that can also prevent cavitation. Therefore, some of the observed characteristics of the Velloziaceae tracheary elements can be used in cladistic analyses and may be adapted to the harsh environment that these plants occupy.

KeY Words: Velloziaceae, xylem, water stress, phylogenetic systematics. 


\section{INTRODUÇÃo}

Um dos primeiros trabalhos em que informações do registro fóssil e da anatomia do xilema foram utilizadas para explicar tendências evolutivas foi o de Bailey \& Tupper (1918), que realizaram o estudo do xilema de espécies de diversos grupos vegetais como as pteridófitas, gimnospermas e angiospermas, estudo que foi posteriormente complementado por Frost (1930A, 1930B, 1931).

Dentro de uma abordagem gradista, Bailey (1944, Bailey \& Tupper 1918) argumentou que os elementos de vaso das angiospermas surgiram a partir de traqueídes. Assim, elementos de vaso semelhantes às traqueídes são primitivos em relação àqueles distintos destas (Stern 1978). Os elementos de vaso surgiram a partir de traqueídes com pontoações areoladas escalariformes através da perda progressiva das membranas das pontoações nas regiões onde as traqueídes se justapõem. $O$ elemento de vaso primitivo reteve restos das membranas das pontoações e possui placa de perfuração inclinada, escalariforme, com muitas barras. A partir dele, o número de barras na placa de perfuração diminuiu, até esta se tornar simples e transversal (Bailey \& Tupper 1918). Bailey (1944) inferiu também, que os caracteres observados no xilema constituem evidências evolutivas confiáveis quanto aos estágios de especialização dos vasos, pois estes estão presentes, representativamente, em angiospermas viventes.

Na mesma linha de raciocínio de Bailey, podese citar os trabalhos de Cheadle (1942, 1943A, 1943B,
1953A, I969 e Cheadle \& Kosakai I97I) que foi o primeiro a estudar os elementos traqueais das monocotiledôneas. Cheadle (1942) descreveu os tipos de elementos traqueais presentes em cada família, observando assim que algumas apresentam elementos de vaso apenas na raiz, outras na raiz e no caule e outras em todos os órgãos da planta.

Nos trabalhos subseqüentes, Cheadle (1943A, 1943B) inferiu que os elementos de vaso em monocotiledôneas evoluíram da raiz para a folha e que, entre as espécies onde ocorre uma ampla variação nos tipos de elementos de vaso de órgão para órgão, os vasos da raiz são sempre os mais especializados. Cheadle (1943B) observou que, assim como para as dicotiledôneas, o elemento de condução primitivo das monocotiledôneas é a traqueíde e que, neste grupo, os elementos de vaso também derivam de uma série de tipos morfológicos distintos de traqueídes.

Em contraposição às idéias gradistas de Bailey e Cheadle, abordagens mais recentes, com a utilização de caracteres anatômicos do xilema à luz da sistemática filogenética, demonstraram consistentemente que elementos de vaso surgiram ou foram perdidos diversas vezes em diferentes grupos vegetais (Baas \& Wheeler 1996). Young (198I) foi o primeiro a afirmar que seria mais parcimonioso assumir que vasos estavam presentes no ancestral comum das angiospermas e foram perdidos em muitos táxons, do que assumir diversas origens para os elementos de vaso. Essa hipótese foi 
confirmada por Donoghue \& Doyle (1989) através de análises filogenéticas, mas foi contestada por Carlquist (1992, 1996) baseado em características funcionais.

Doyle \& Endress (2000) realizaram uma análise filogenética combinada para as angiospermas e avaliaram a ocorrência de elementos de vaso, propondo que o estado plesiomórfico é a ausência de elementos de vaso, já que o grupo basal das angiospermas (Amborellaceae) possui apenas traqueídes. Sendo assim, é mais parcimonioso assumir que os vasos tiveram uma origem comum e foram perdidos algumas vezes ao longo da evolução (Doyle \& Endress 2000). Apesar da origem dos elementos de vaso ter sido bastante discutida em trabalhos de filogenia, as hipóteses de Cheadle para a origem e diversificação dos elementos de vaso nas monocotiledôneas ainda não foram testadas com base na sistemática filogenética. Recentemente, diversos trabalhos descritivos, mostrando a diversidade dos elementos traqueais de algumas famílias de monocotiledôneas, foram publicados (Carlquist \& Schneider 1997, 1998A, 1998B, 2006, Schneider \& Carlquist 1997, 1998, 2005A, 2005B) onde as informações não são claramente aplicadas às filogenias existentes e

\section{Material e Métodos}

Foram estudados de um a três espécimes de vinte e oito espécies de Velloziaceae, representantes dos nove gêneros já descritos para a família (Menezes 197I, Kubitzki 1998) e, quando possível, utilizou-se indivíduos de diferentes populações. Além disso, foi utilizada uma espécie de Cyclanthaceae, uma de Pandanaceae e uma discutidas sob este paradigma.

Velloziaceae é um grupo das monocotiledôneas onde caracteres anatômicos são extremamente importantes para a identificação e como fonte de caracteres para análises filogenéticas (Menezes et al. 1994, Mello-Silva 2000, 2005). Em relação aos elementos traqueais da família, dados sobre o tipo de elemento traqueal presente nos diferentes órgãos de Velloziaceae são encontrados (Fahn 1954, Cheadle 1968,Ayensu 1968, Menezes et al. 1990). Apesar da disponibilidade de alguns dados referentes aos elementos traqueais da família na literatura, os trabalhos de Fahn (1954), Cheadle (1968) e Ayensu (1968) somam juntos, dados de apenas cinco espécies. Já o de Menezes et al. (1990) não deixa claro quais espécies de cada gênero foram utilizadas. Além disso, tem-se disponível na literatura (Mello-Silva 2005), uma ampla matriz morfológica onde novos caracteres podem ser testados em análises cladísticas. Sendo assim, este estudo tem como objetivos:

- avaliar a diversidade dos elementos traqueais nos diferentes órgãos vegetativos de Velloziaceae e, - verificar se características dos elementos traqueais são filogeneticamente informativas.

de Bromeliaceae como representantes do grupo externo.A lista de espécies e vouchers encontra-se na tabela I.

As porções radiculares, caulinares e foliares coletadas foram armazenadas em uma solução de glicerina $50 \%$ em água destilada e formol $4 \%$. 
Tabela I: Lista das espécies utilizadas, suas respectivas famílias e vouchers.

\begin{tabular}{|c|c|c|}
\hline EsPÉCIE & Família & VOUCHER \\
\hline Acanthochlamys bracteata P.C. Kao & Velloziaceae & Kao s.n. \\
\hline Aylthonia umbrosa (L. B. Sm. \& Ayensu) & Velloziaceae & $\begin{array}{l}\text { Harley CFCR } 6477 \\
\text { Mello-Silva CFCR6477 }\end{array}$ \\
\hline Barbacenia ignea Mart. & Velloziaceae & Mello-Silva 2554 \\
\hline Barbacenia reflexa L. B. Sm. \& Ayensu & Velloziaceae & Mello-Silva CFCRI0793 \\
\hline Barbaceniopsis castillonii (Hauman) Ibisch & Velloziaceae & Mello-Silva 1857 \\
\hline Burlemarxia spiralis (L.B.Sm. \& Ayensu) N.L.Menezes \& J.Semir & Velloziaceae & Mello-Silva 2548 \\
\hline Nanuza plicata (Mart.) L. B Sm. \& Ayensu & Velloziaceae & $\begin{array}{l}\text { Cattai 01 } \\
\text { Cattai } 02\end{array}$ \\
\hline Pleurostima longiscapa (Goethart \& Henrard) N. L. Menezes & Velloziaceae & $\begin{array}{l}\text { Mello-Silva } 1776 \\
\text { Mello-Silva } 2553\end{array}$ \\
\hline Pleurostima plantaginea (L. B. Sm.) & Velloziaceae & Salatino CFCR II 901 \\
\hline Pleurostima riparia N. L. Menezes \& Mello-Silva & Velloziaceae & Menezes II67 \\
\hline Talbotia elegans Balf. & Velloziaceae & Cultivada xx-0-BONN-764 \\
\hline Vellozia abietina Mart. & Velloziaceae & $\begin{array}{l}\text { Mello-Silva } 1777 \\
\text { Mello-Silva } 2673\end{array}$ \\
\hline Vellozia alata L. B. Sm. & Velloziaceae & Mello-Silva 2368 \\
\hline Vellozia albiflora Pohl & Velloziaceae & $\begin{array}{l}\text { Menezes } 528 \\
\text { Mello-Silva } 2132\end{array}$ \\
\hline Vellozia burlemarxii L. B. Sm. \& Ayensu & Velloziaceae & Mello-Silva 2I 48 \\
\hline Vellozia caudata Mello-Silva & Velloziaceae & Mello-Silva 2132 \\
\hline Vellozia hemisphaerica Seub. & Velloziaceae & $\begin{array}{l}\text { Mello-Silva } 2576 \\
\text { Mello-Silva } 2800 \\
\text { Mello-Silva } 2828\end{array}$ \\
\hline Vellozia hirsuta Goethart \& Henrard & Velloziaceae & $\begin{array}{l}\text { Mello-Silva } 2576 \\
\text { Mello-Silva } 2698\end{array}$ \\
\hline Vellozia jolyi L. B. Sm. & Velloziaceae & $\begin{array}{l}\text { Mello-Silva } 2145 \\
\text { Mello-Silva } 2146\end{array}$ \\
\hline Vellozia minima Pohl & Velloziaceae & Mello-Silva 2666 \\
\hline Vellozia prolifera Mello-Silva & Velloziaceae & Mello-Silva 2560 \\
\hline Vellozia punctulata Seub. & Velloziaceae & Mello-Silva 2587 \\
\hline Xerophyta dasylirioides Baker & Velloziaceae & Puy 176 \\
\hline Xerophyta eglandulosa Baker & Velloziaceae & Puy 169 \\
\hline Xerophyta pinifolia Lam. & Velloziaceae & Puy 167 \\
\hline Encholirium scrutor (L. B. Sm.) Rauh & Bromeliaceae & Forzza 1488 \\
\hline Pandanus racemosus Kurz & Pandanaceae & Pirani 4755 \\
\hline Thoracocarpus bissectus (Vell.) Harling & Cyclanthaceae & Fiaschi \& Lobão 533 \\
\hline
\end{tabular}

Para a análise dos elementos traqueais, porções radiculares, caulinares e foliares foram dissociadas em estufa, imersas em uma solução de peróxido de hidrogênio e ácido acético glacial $(I: I \mathrm{v} / \mathrm{v})$ durante 24-48h (Franklin 1945). Posteriormente o material foi lavado com água destilada e corado com azul de astra $1 \%$ em etanol $50 \%$ e/ou safranina $1 \%$ em etanol $50 \%$ (Bukatsch 1972), durante alguns minutos, sendo então montado em lâmina semi-permanente, com glicerina. Como, em uma primeira análise, se observou que os elementos traqueais radiculares eram muito semelhantes, foram elaboradas 5 lâminas da raiz de cada espécime analisada. Já para o caule e folha, foram elaboradas dez lâminas de cada espécime e, no total, I 200 lâminas foram analisadas.

Em Velloziaceae, o caule é recoberto pelas bainhas foliares e, entre elas, ocorrem raízes que estão presentes junto ao caule ao longo de toda planta. Sendo assim, para a realização da dissociação da porção caulinar as bainhas foliares e raízes foram completamente retiradas de forma que só a porção caulinar fosse dis- 
sociada. Para preparo das amostras para microscopia eletrônica de varredura, o material dissociado sofreu desidratação em série cetônica, as amostras foram aderidas a suportes metálicos e cobertas com ouro.

Para a análise da organização estrutural radicular e caulinar foram realizadas secções histológicas do caule e raiz de cada espécie. Não foram realizadas secções foliares uma vez que o laminário utilizado por Mello-Silva para os determinar os caracteres foliares utilizados em análises cladísticas (Mello-Silva 2000, 2005) estava disponível para consulta.As porções caulinares e radiculares foram infiltradas e incluídas em polietilenoglicol (PEG) I500, segundo Gerlach (1984). Posteriormente, o material foi seccionado em micrótomo de deslize, corado com azul de astra $1 \%$ em etanol $50 \%$ e safraninal\% em etanol $50 \%$ (Bukatsch

\section{Resultados}

\section{Elementos tRAQUeAis RADICULARES:}

As raízes de Velloziaceae possuem até 15 pólos de protoxilema e os elementos traqueais do metaxilema são facilmente identificados em secção transversal (figura I). Os elementos traqueais radiculares de Velloziaceae não variam muito entre os tipos e formas nas diferentes espécies estudadas e estão representados na figura 3.Todas as espécies da família analisadas possuem elementos de vaso do metaxilema com placas de perfuração simples na raiz (figuras 4 e 5 ) e estes podem ser identificados em secção longitudinal (figura 2) e em material dissociado (figura 3). Estes elementos de vaso possuem pontoações
1972), desidratados e montados em resina sintética. O material herborizado foi reidratado com água e glicerina $(I: I \mathrm{v} / \mathrm{v})$ para que fosse submetido à técnica de infiltração acima descrita.

O material dissociado foi analisado sob microscopia de luz e microscopia eletrônica de varredura e suas variações registradas através de desenhos em câmara clara e fotomicrografias. $\bigcirc$ registro em câmara clara se deu de forma que todos os tipos e variações de elementos traqueais fossem representados, sem registrar as diferenças de freqüência de tipo e forma de elemento traqueal. Considerou-se, na análise, apenas os elementos traqueais do metaxilema. Assim, elementos com espessamento anelar ou helicoidal foram excluídos dos resultados, uma vez que estão presentes em todos os órgãos e espécies.

areoladas apenas na parede do vaso que se comunica com outros vasos estando as demais porções da parede completamente ausentes de pontoações (figuras 4 e 5). Dentro de uma mesma espécie e entre as espécies é comum encontrar elementos de vaso com pequena variação no diâmetro e comprimento e elementos de vaso com e sem apêndices. Quanto ao grupo externo, Thoracocarpus bissectus e Encholirium scrutor apresentam elementos de vaso com placa de perfuração escalariforme (figura 6). Em E. scrutor também são encontradas traqueídes e Pandanus racemosus possui apenas traqueídes na raiz. 


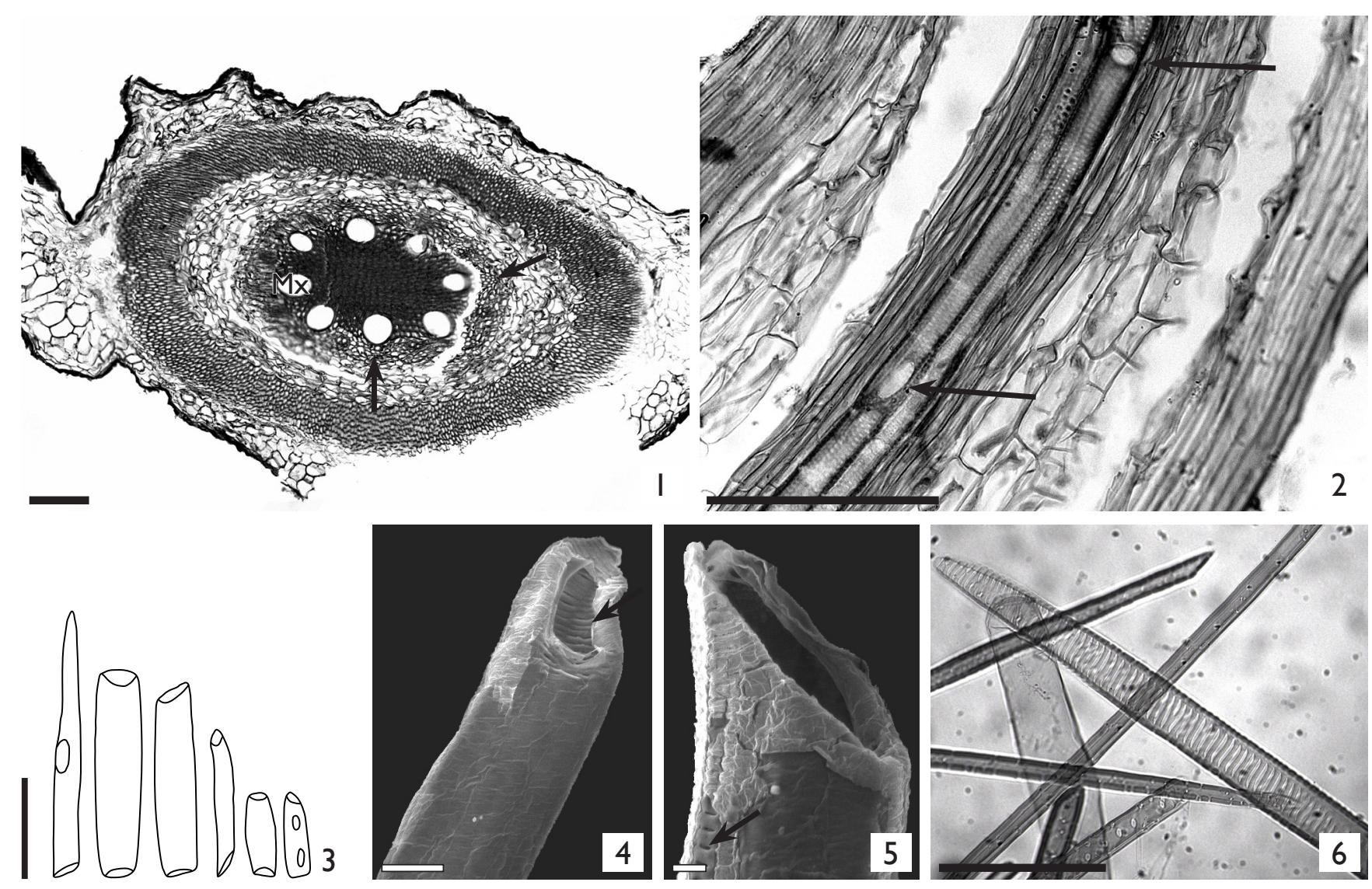

Figuras I a 5: Elementos de vaso radiculares de Velloziaceae. I: Secção trasversal da raiz de Barbaceniopsis castillonii evidenciando os pólos de protoxilema (setas) e elementos de metaxilema (Mx). 2: Secção longitudinal da raiz de Acanthochlamys bracteata onde se observa os elementos de vaso com placa de perfuração simples (setas) formando um vaso. 3: Desenho em câmara clara da variação dos elementos de vaso observados nas espécies analisadas. 4 e 5: Microscopia eletrônica de varredura de elementos de vaso radiculares de Talbotia elegans. 4: Elemento de vaso com placa de perfuração simples no qual se observa a parede com (seta) e sem pontoações. 5:Detalhe da placa de perfuração e das pontoações em apenas uma parte da parede do elemento (seta). 6: Elemento de vaso radicular de Thoracocarpus bissectus, com placa de perfuração escalariforme. Barra: I, 2 e $6=100 \mu \mathrm{m}, 3=200 \mu \mathrm{m}, 4=10 \mu \mathrm{m}, 5=5 \mu \mathrm{m}$.

\section{Elementos traqueais CAULINARES:}

Através de secções transversais e longitudinais do caule não é possível identificar o tipo de elemento traqueal do metaxilema presente nos feixes vasculares já que estes possuem diâmetro semelhante e não foi obtida nenhuma secção onde fosse possível a identificação de uma placa de perfuração (figuras 7 e 8). Em secção longitudinal é possível observar os elementos de proto e metaxilema (figura 9), mas não é possível identificar o tipo de elemento traqueal. Sendo assim, apenas com a dissociação do material foi possível definir os elementos traqueais caulinares do metaxilema de Velloziaceae.

A análise dos elementos traqueais caulinares mostrou uma grande variação de tipos, tamanho e forma entre os gêneros e espécies de Velloziaceae, que podem ser visualizadas nas figuras 10 a 21 . 



Figuras 7 a 9: Secções do caule de Burlemarxia spiralis. 7: Secção transversal evidenciando a disposição dos feixes vasculares. 8: Detalhe do feixe vascular em seção transversal onde não se observa diferença significativa no diâmetro dos elementos traqueais do metaxilema (seta). 9: Secção longitudinal onde é possível observar os elementos traqueais de protoxilema (Px) e de metaxilema (Mx) de um feixe vascular. Barra de escala $=100 \mu \mathrm{m}$.

Todas as espécies analisadas, à exceção de Acanthochlamys bracteata, possuem traqueídes no caule. Apenas duas Velloziaceae (Barbaceniopsis castillonii - figura 18 e Talbotia elegans - figura 16) apresentam somente traqueídes no caule sendo que as demais possuem tanto traqué́des quanto elementos de vaso no caule. As traqueídes, em todas as espécies, são tortuosas e às vezes, bifurcadas (figuras $10-21$ ). A tortuosidade dos elementos traqueais caulinares faz com seja muito difícil acompanhar um feixe vascular em secções longitudinais e que se observe elementos de vaso compondo um vaso (figura 9). Embora a freqüência de traqueídes em relação aos elementos de vaso não tenha sido quantificada, a predominância de traqueídes é marcante, sendo muito rara a observação de mais de 10 elementos de vaso por lâmina.

Os elementos de vaso das espécies analisadas apresentam placa de perfuração escalariforme com muitas barras (mais de cinco - figuras 10 e I2) ou simples (figuras II, I3, I4, I5, I9, 2I), como ocorre na maioria das Velloziaceae analisadas. Algumas espécies apresentam elementos de vaso com placa de perfuração escalariforme com poucas barras (menos de cinco) e com placa de perfuração simples (Nanuza plicata, figura 17 e Pleurostima plantaginea, figura 20). Em Nanuza plicata é possível observar ainda a presença de ambos os tipos de placas em um único elemento de vaso. Placas de perfuração podem estar presentes em apenas uma das extremidades do elemento de vaso (figuras 17 e 19). Características como tipo de elemento traqueal, comprimento e diâmetro variam em um mesmo indivíduo, em uma mesma espécie e entre as espécies analisadas. A maior variação é observada em Vellozia hemisphaerica (figura 2I).

Sob microscopia eletrônica é possível observar o espessamento da parede dos elementos traqueais de Velloziaceae com maior acuidade. Nas traqueídes, o espessamento pode ser reticulado (Barbacenia ignea - figura 22, Talbotia elegans - figura 23), sendo comum observar espessamento escalariforme e reticulado em um mesmo elemento traqueal (Talbotia elegans - figura 24), ou pode apresentar pontoações areoladas (Burle- 

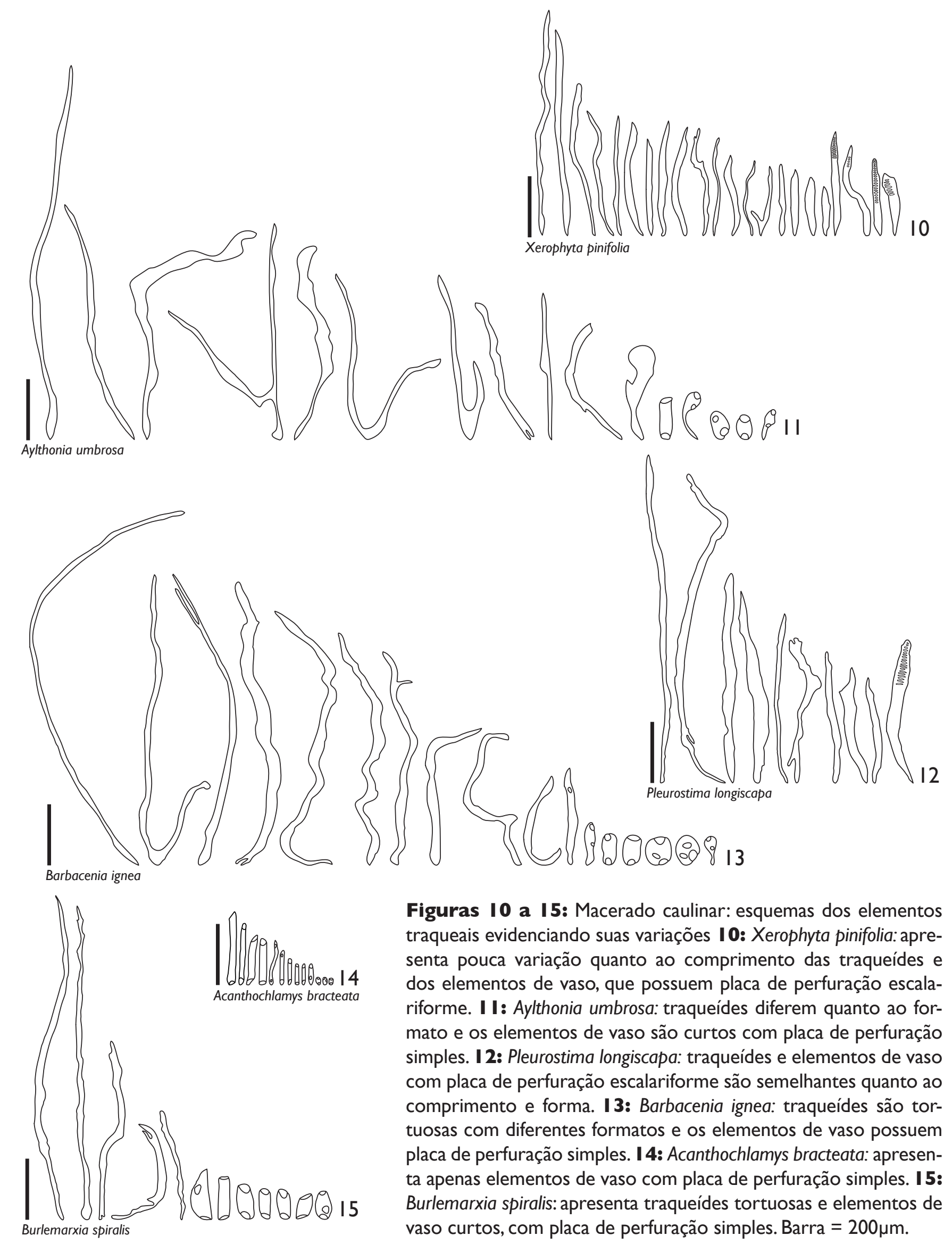

Figuras 10 a 15: Macerado caulinar: esquemas dos elementos traqueais evidenciando suas variações I0: Xerophyta pinifolia: apresenta pouca variação quanto ao comprimento das traqueídes e dos elementos de vaso, que possuem placa de perfuração escalariforme. I I: Aylthonia umbrosa: traqueídes diferem quanto ao formato e os elementos de vaso são curtos com placa de perfuração simples. I 2: Pleurostima longiscapa: traqueídes e elementos de vaso com placa de perfuração escalariforme são semelhantes quanto ao comprimento e forma. I3: Barbacenia ignea: traqueídes são tortuosas com diferentes formatos e os elementos de vaso possuem placa de perfuração simples. I4: Acanthochlamys bracteata: apresenta apenas elementos de vaso com placa de perfuração simples. I 5: Burlemarxia spiralis: apresenta traqueídes tortuosas e elementos de vaso curtos, com placa de perfuração simples. Barra $=200 \mu \mathrm{m}$. 

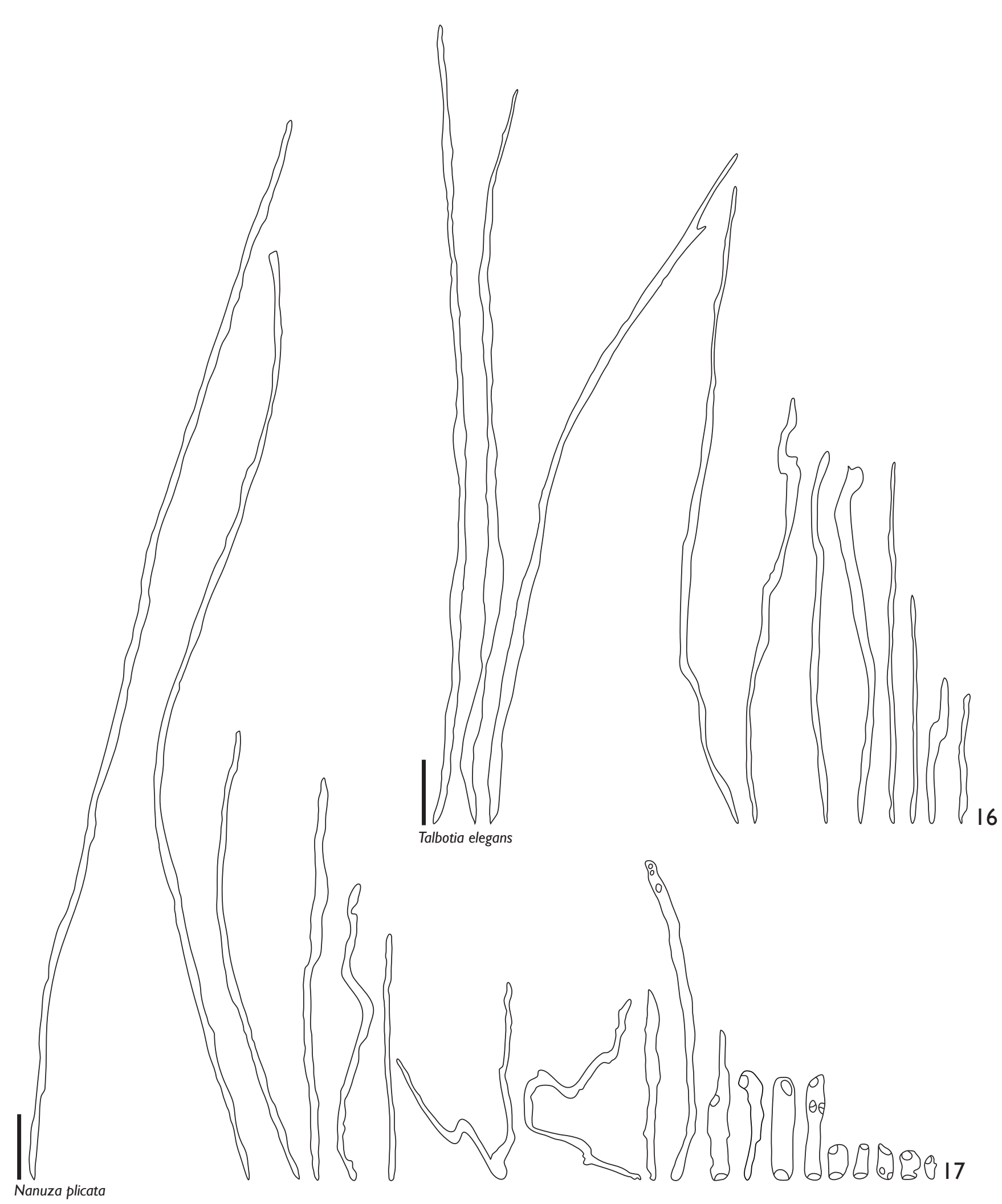

Figuras 16 e 17: Macerado caulinar: esquemas dos elementos traqueais evidenciando suas variações 16: Talbotia elegans: apresenta apenas traqueídes no caule que variam quanto ao comprimento. I 7: Nanuza plicata: apresenta desde traqueídes muito longas a curtas, com formatos diversos, assim como os elementos de vaso, que possuem placa de perfuração simples e, eventualmente, com poucas barras. Barra $=200 \mu \mathrm{m}$. 

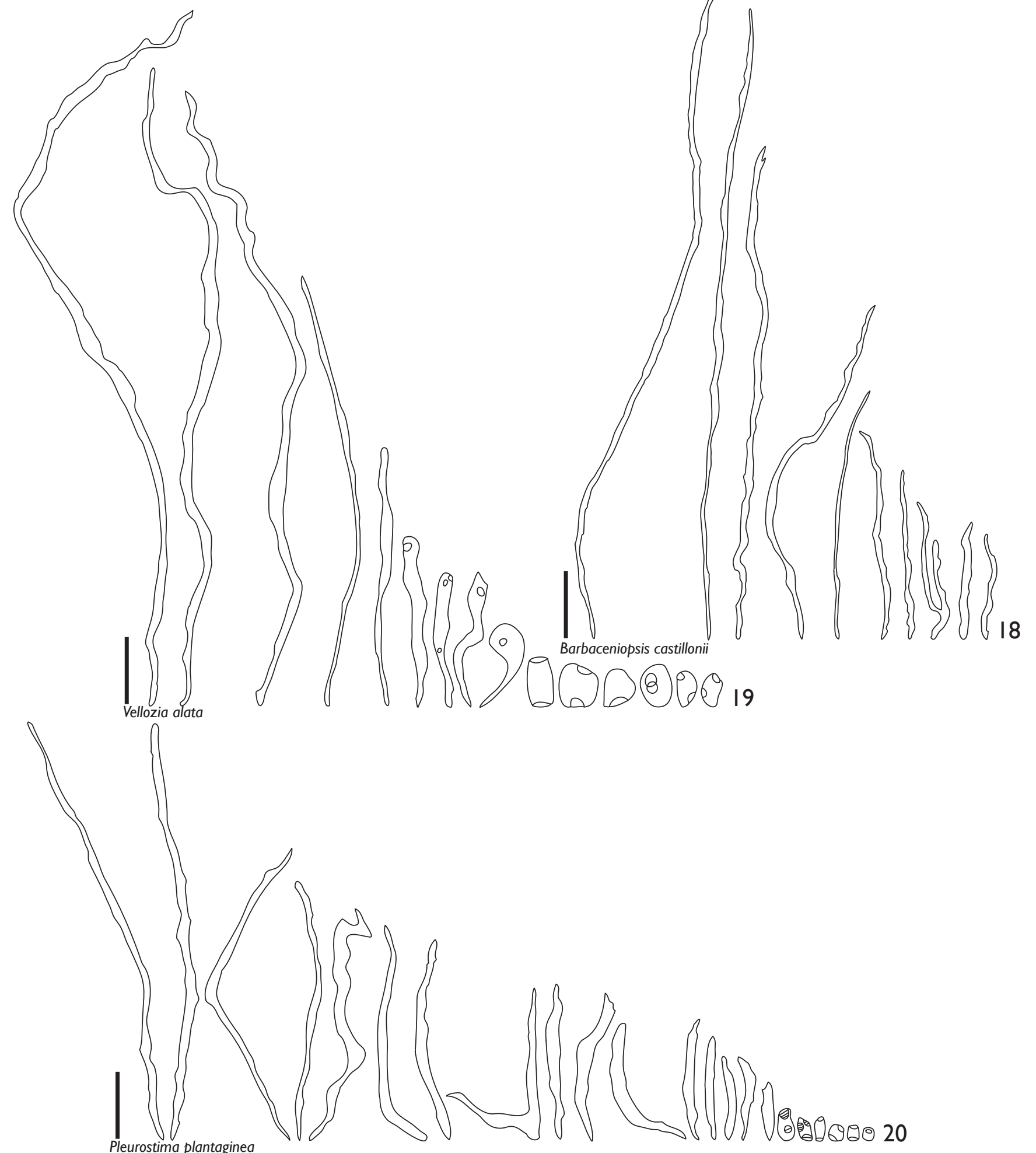

Figuras I8 a 20: Macerado caulinar: esquemas dos elementos traqueais evidenciando suas variações I8: Barbaceniopsis castillonii: apresenta apenas traqueídes que variam quanto ao comprimento. 19: Vellozia alata: traqueídes e elementos de vaso, com placa de perfuração simples, possuem variação quanto ao comprimento. 20: Pleurostima plantaginea: traqueídes diferem quanto ao comprimento e forma e elementos de vaso são curtos com placa de perfuração escalariforme com poucas barras e simples. Barra $=200 \mu \mathrm{m}$. 


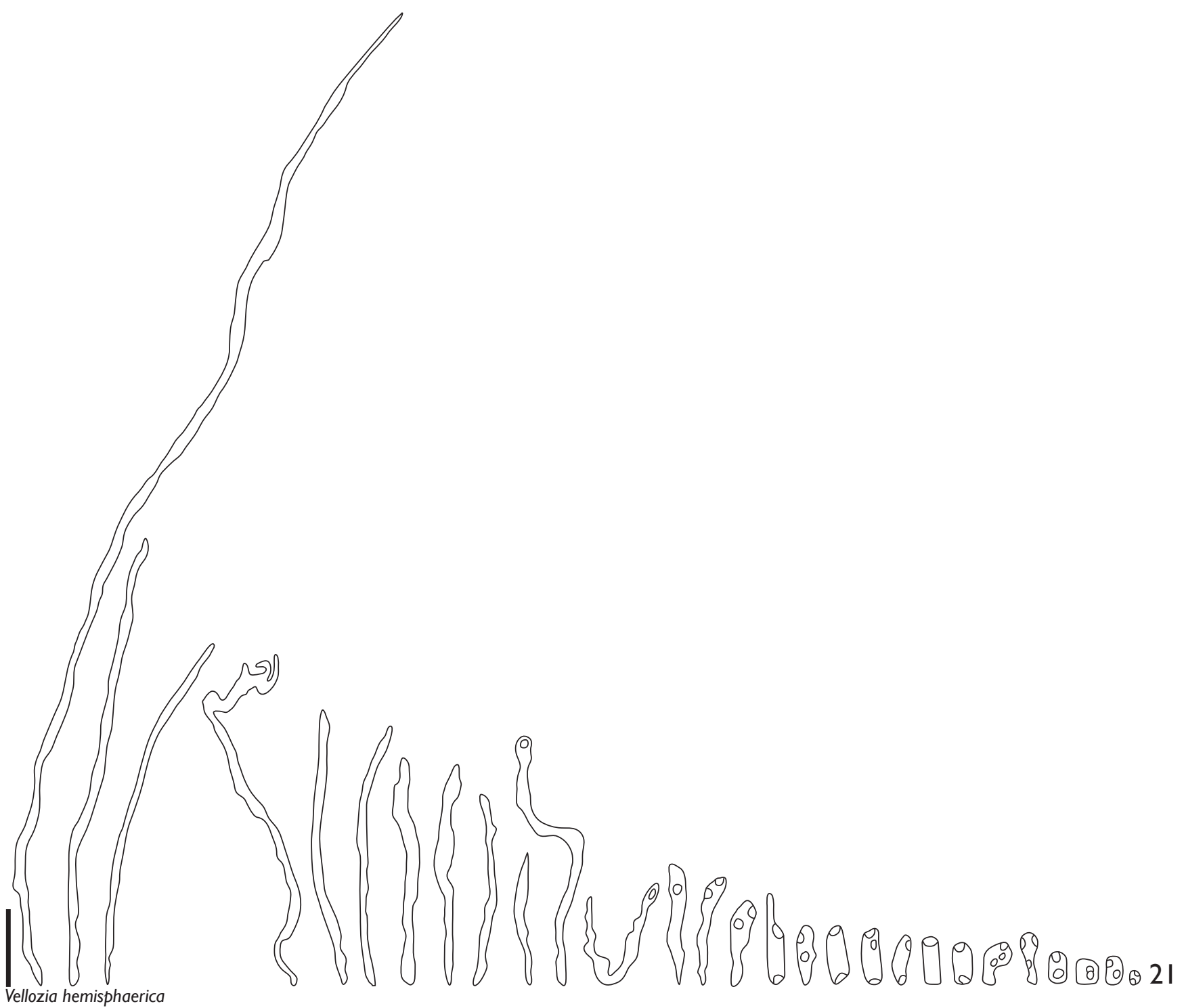

2 I: Macerado caulinar: esquemas dos elementos traqueais evidenciando suas variações. Vellozia hemisphaerica: possui desde traqueídes muito longas até elementos de vaso muito curtos, com placa de perfuração simples.. Barra $=200 \mu \mathrm{m}$.

marxia spiralis - figura 24 e Vellozia hemisphaerica - figura 26). Também é possível observar a forma angular das paredes das traqueídes (figura 26).

Nos elementos de vaso, se observam placas de perfuração escalariforme com muitas barras (figura 27 e 28) e com espessamento da parede lateral reticulado (Xerophyta dasylirioides - figura 28) e pontoado (Pleurostima longiscapa - figura 27). Já em Vellozia hemisphaerica (figura 29) e Burlemarxia spiralis (figura 30) se observam elementos de vaso com pontoações areoladas e placa de perfuração simples, que podem ocorrer nas extremidades do elemento (figura 30) e, também, nas paredes laterais (figura 29).

Apesar das raízes, que crescem junto ao caule das Velloziaceae, terem sido minuciosamente destacadas antes da dissociação da porção caulinar, é possível 

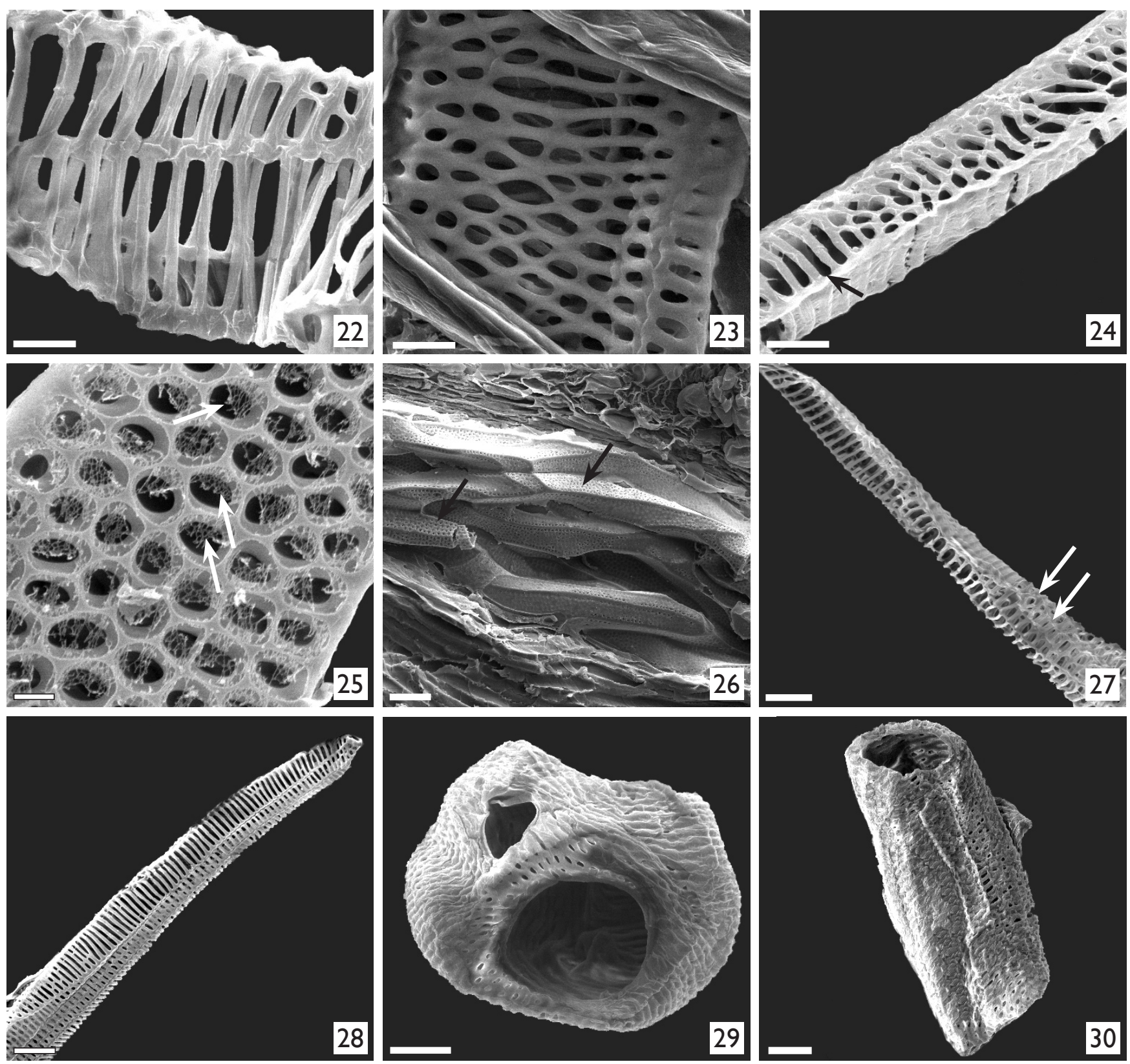

Figuras 22 a 30: Elementos traqueais de Velloziaceae sob microscopia eletrônica de varredura. 22 a 26: Traqueídes. 22: Barbacenia ignea com espessamento de parede reticulado. 23 e 24: Talbotia elegans com espessamento de parede reticulado (23) e reticulado e escalariforme (seta, figura 24). 25: Traqueíde de Burlemarxia spiralis com pontoações areoladas onde se observam restos de parede primária de forma reticulada (setas). 26: Detalhe do feixe de Vellozia hemisphaerica evidenciando traqueídes com paredes angulares e pontoações (setas) 27: Elemento de vaso de Pleurostima longiscapa com placa de perfuração escalariforme com muitas barras e parede lateral pontoada (setas). 28: Elemento de vaso com placa de perfuração escalariforme em Xerophyta dasylirioides 29: Elemento de vaso diminuto de Vellozia hemisphaerica evidenciando placas de perfuração simples 30: Elemento de vaso com placa de perfuração simples em Burlemarxia spiralis. Barra: 26, 27 e $28=20 \mu \mathrm{m}, 29=10 \mu \mathrm{m}$, $22,23,24$ e $30=5 \mu \mathrm{m}, 25=2 \mu \mathrm{m}$. 
encontrar elementos de vaso radiculares na dissociação das porções caulinares. Com a análise das secções transversais caulinares se observa que as raízes são formadas no caule (figuras 3 I e 32 ) e, antes de deixarem o caule, possuem elementos de vaso já diferenciados (figura 32). Na figura 33 se observa uma raiz já formada junto ao caule, apresentando os tecidos diferenciados. Apesar disso, com a análise do material radicular dissociado observou-se que os elementos de vaso radiculares não possuem pontoações ao longo de toda a parede, característica esta que permite separar os elementos de vaso pertencentes à raiz dos caulinares presentes em uma mesma maceração.

Quando ao grupo externo, todas as espécies analisadas apresentam apenas traqueídes no caule.
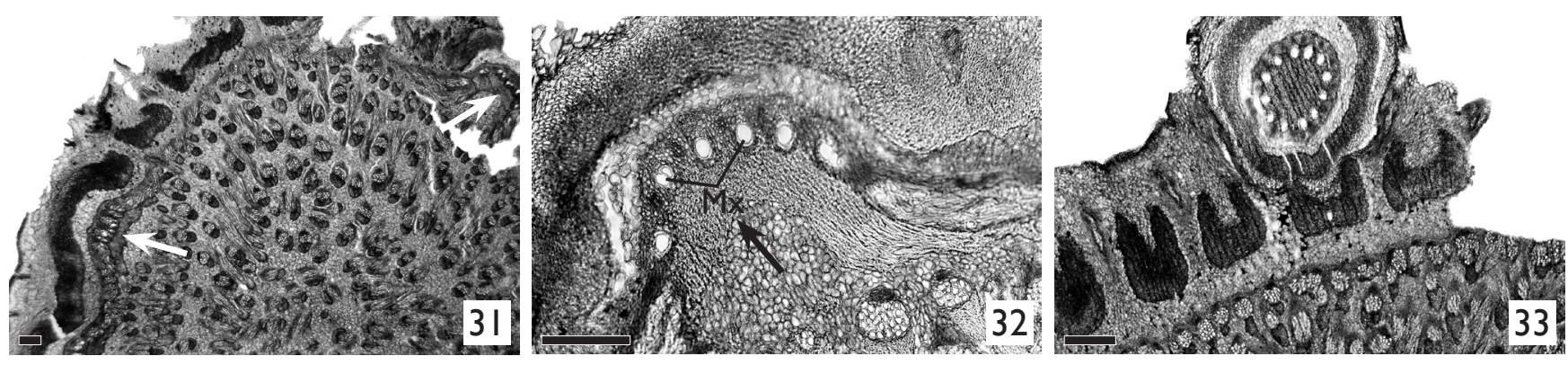

Figuras 3 I a 33: Secção transversal de Barbaceniopsis castillonii evidenciando a saída de raízes adventícias. 3 I e 32: Formação de raízes no caule (setas). Antes das raízes deixarem o caule, os elementos de vasos do metaxilema $(M x)$ já se encontram diferenciados. 33: Raiz já formada deixando o caule. Barra $=200 \mu \mathrm{m}$.

\section{ELEMENTOS TRAQUEAIS FOLIARES:}

As macerações das porções foliares evidenciam a presença de elementos de vaso com placa de perfuração escalariforme com muitas barras (figuras 36 e 37) em todas as espécies da família, à exceção de Talbotia elegans. Na figura 36 está representada a variação de tipos e formas dos elementos traqueais foliares nas espécies estudadas. É comum observar traqueídes longas e finas com espessamento anelar e helicoidal, que compõem o protoxilema, e elementos traqueais do metaxilema, que possuem maior diâmetro, indicados nas figuras 34 e 35 . Em algumas espécies também são observadas traqueídes de maior diâmetro com espessamento reticulado, pertencentes ao metaxile- ma. Assim como as traqueídes pertencentes ao metaxilema de algumas espécies, os elementos de vaso também possuem espesamento reticulado (figura 38).

A grande diversidade de tipos e formas dos elementos traqueais caulinares de Velloziaceae torna difícil o estabelecimento de caracteres para utilização em análise cladística. Caracteres muito utilizados em descrições de espécies arbóreas como diâmetro e comprimento dos elementos traqueais e tamanho e arranjo das pontoações intervasculares não podem ser utilizados paraVelloziaceae uma vez que variam muito em uma mesma espécie e em um mesmo indivíduo. Além disso, os elementos traqueais 

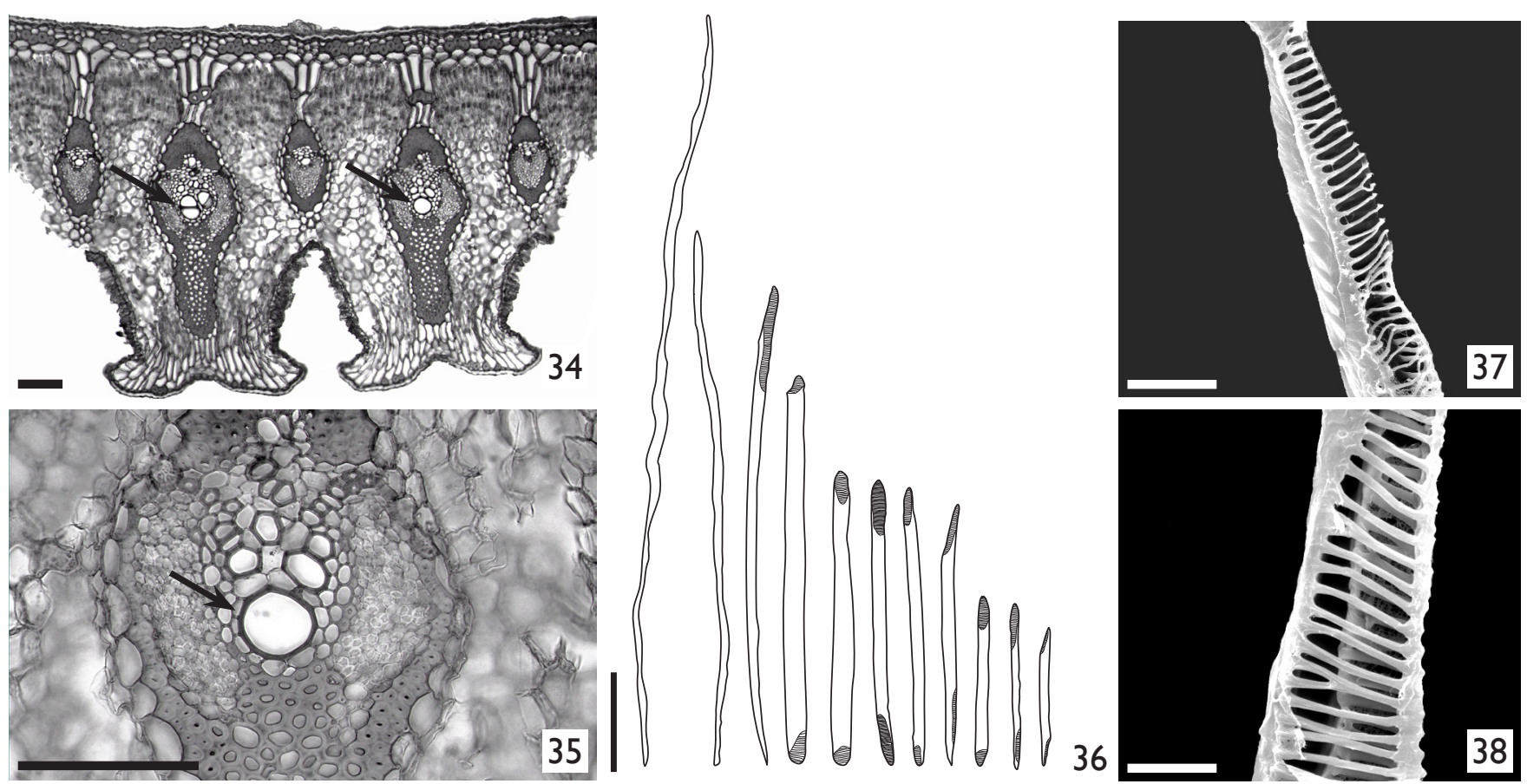

Figuras 34 a 37: Elementos traqueais foliares de Velloziaceae. 34 e 35: Secção transversal foliar de Vellozia hemisphaerica evidenciando a disposição dos tecidos vasculares e os elementos de metaxilema da maior diâmetro (setas). 36: Variação dos elementos traqueais observada na folha. 37: Placa de perfuração escalariforme com muitas barras em Vellozia hemisphaerica. 38: Espessamento escalariforme da parede de um elemento de vaso de Vellozia hemisphaerica. Barra: 34 e $35=100 \mu \mathrm{m}, 36=200 \mu \mathrm{m}, 37$ e $38=10 \mu \mathrm{m}$.

radiculares e foliares são muito semelhantes nas espécies da família e assim, apenas o tipo de elemento traqueal e o tipo de placa de perfuração constituem caracteres que podem ser incluídos em análises filogenéticas.
A seguir, é apresentada a lista de possíveis caracteres informativos observados (tabela II) e os resultados obtidos em cada espécie analisada apresentados em uma matriz (tabela III).

Tabela II: Lista de caracteres observados nos elementos traqueais de Velloziaceae e sua codificação
I - Elemento de vaso na raiz
ausente (0)
presente (I)
2 - Tipo de placa de perfuração dos elementos de vaso radiculares escalariforme (0) simples ( 1 )

\section{3 - Elemento de vaso no caule} ausente (0) presente ( 1$)$

\section{4 - Tipo de placa de perfuração dos elementos de vaso caulinares}

escalariforme com muitas barras: $\geq 5$ (0) escalariforme com poucas barras: $\leq 5$ (I) simples (2)

\section{5 - Elemento de vaso na folha presente (0) ausente (I)}

6 - Tipo de placa de perfuração dos elementos de vaso foliares

escalariforme (0)

simples (I) 
Tabela III: Matriz dos resultados obtidos na análise dos elementos traqueais de Velloziaceae (ver tabela II para a codificação dos caracteres. ? dados ausentes, - inaplicável)

\begin{tabular}{|c|c|c|c|c|c|c|}
\hline Espécie & $\mathbf{I}$ & 2 & 3 & 4 & 5 & 6 \\
\hline Acanthochlamys bracteata & 1 & 1 & 1 & 2 & 1 & 0 \\
\hline Aylthonia umbrosa & 1 & I & 1 & 2 & 1 & 0 \\
\hline Barbacenia ignea & I & I & 1 & 2 & 1 & 0 \\
\hline Barbacenia reflexa & I & I & $?$ & $?$ & 1 & 0 \\
\hline Barbaceniopsis castillonii & $?$ & $?$ & 0 & - & 1 & 0 \\
\hline Burlemarxia spiralis & 1 & I & 1 & 2 & 1 & 0 \\
\hline Encholirium scrutor & I & 0 & 0 & - & 0 & - \\
\hline Nanuza plicata & 1 & I & 1 & $1 / 2$ & 1 & 0 \\
\hline Pandanus racemosus & 0 & - & 0 & - & 0 & - \\
\hline Pleurostima longiscapa & 1 & I & 1 & 0 & 1 & 0 \\
\hline Pleurostima plantaginea & 1 & I & 1 & $\mathrm{I} / 2$ & 1 & 0 \\
\hline Pleurostima riparia & I & I & 1 & 2 & 1 & 0 \\
\hline Talbotia elegans & 1 & I & 0 & - & 0 & - \\
\hline Thoracocarpus bissectus & 1 & 0 & 0 & - & 0 & - \\
\hline Vellozia abietina & 1 & I & 1 & 2 & 1 & 0 \\
\hline Vellozia alata & I & I & I & 2 & 1 & 0 \\
\hline Vellozia albiflora & 1 & I & I & 2 & 1 & 0 \\
\hline Vellozia burlemarxii & 1 & I & 1 & 2 & 1 & 0 \\
\hline Vellozia caudata & I & I & I & 2 & 1 & 0 \\
\hline Vellozia hemisphaerica & I & I & 1 & 2 & 1 & 0 \\
\hline Vellozia hirsuta & 1 & I & I & 2 & 1 & 0 \\
\hline Vellozia jolyi & 1 & I & 1 & 2 & 1 & 0 \\
\hline Vellozia minima & 1 & I & I & 2 & 1 & 0 \\
\hline Vellozia prolifera & I & I & 1 & 2 & 1 & 0 \\
\hline Vellozia punctulata & 1 & I & I & 2 & 1 & 0 \\
\hline Xerophyta dasylirioides & $?$ & $?$ & I & 0 & 1 & 0 \\
\hline Xerophyta eglandulosa & 1 & I & I & 0 & 1 & 0 \\
\hline Xerophyta pinifolia & $?$ & $?$ & 1 & 0 & I & 0 \\
\hline
\end{tabular}

\section{Discussão}

Todas as espécies de Velloziaceae analisadas apresentam elementos de vaso com placas de perfuração simples na raiz concordando com o que havia sido observado em algumas espécies por Fahn (1954), Cheadle (1968) e Menezes et al. (1990). Porém, nas espécies do grupo externo, os elementos de vaso radiculares possuem placas de perfuração escalariforme.
Dado o monofiletismo do grupo comprovado por diversas análises filogenéticas (Chase et al. 1993, 1995, Davis et al. 2004, Mello-Silva 2005, Rudall \& Bateman 2006), a presença de placa simples nos elementos de vaso radiculares de Velloziaceae pode constituir uma sinapomorfia do grupo, além de ser mais uma evidência para a inclusão de Acanthochlamys bracteata na família. 
Além disso, a presença de elementos de vaso no caule e na folha é, dentre as espécies analisadas, característica exclusiva de Velloziaceae. Se otimizadas no cladograma de Mello-Silva (2005), tem-se que estas características seriam sinapomorfias da família e que teriam ocorrido reversões em Barbaceniopsis castillonii e Talbotia elegans que posuem apenas traqueídes no caule e em Talbotia elegans que apresenta traqueídes na folha.

Dos caracteres analisados, a presença de elementos de vaso na raiz e o tipo de placa de perfuração dos elementos traqueais foliares não serão informativas para análises cladísticas. $\mathrm{Na}$ raiz, apenas Pandanus racemosus não apresenta elementos de vaso na raiz, o que constituiria uma autapomorfia da espécie, e na foIha, todas as espécies que possuem elementos de vaso, possuem placa de perfuração escalariforme.

A ausência ou presença de elementos de vaso em folhas de Velloziaceae foi observada por Menezes et al. (1990) e já foi utilizada em análises cladísticas, mostrando ser um caráter informativo para a família (Menezes et al. 1994, Mello-Silva 2000, 2005). Apesar disso, segundo Menezes et al. (1990), apenas espécies de Xerophyta apresentam elementos de vaso na folha, dado discordante das observações aqui descritas.

A diversidade de elementos traqueais caulinares deVelloziaceae não foi relatada na literatura para nenhuma das famílias de monocotiledôneas já estudadas por Cheadle (1942, 1943A, 1943B, 1944, 1953A, 1953B, 1968, 1969, 1975, Cheadle \& Kosakai I97I, 1972), Carlquist \& Schneider (1997, 1998A, 1998B, 2006) ou Schneider \&
Carlquist (1997, 2005A, 2005B).Talbotia elegans, também analisada por Fahn (1954), apresenta apenas traqueídes no caule, mas Cheadle (1968) não relatou a presença deste tipo de elemento traqueal nas três espécies de Velloziaceae por ele estudas, mostrou apenas a presença de elementos de vaso em uma espécies de Barbacenia e duas de Vellozia. Com exceção de Acanthochlamys bracteata, todas as espécies de Velloziaceae analisadas neste estudo apresentam traqueídes no caule, sempre em maior numero que os elementos de vaso.

Menezes et al. (1990), por sua vez, observaram a presença de elementos de vaso apenas em espécies de Xerophyta, o que não concorda com os resultados obtidos neste estudo, uma vez que apenas duas de todas as Velloziaceae analisadas não apresentam elementos de vaso no caule (Barbaceniopsis castillonii e Talbotia elegans).

A freqüência de elementos de vaso no caule das Velloziaceae, é baixa sendo difícil encontrar mais do que dez elementos de vaso em uma mesma lâmina. Assim, através da análise isolada do material dissociado é difícil compreender qual o papel destes elementos de vaso, uma vez que eles não aparentam formar um vaso, mas sim, ligações entre traqueídes. Além disso, as secções longitudinais não foram elucidativas neste aspecto uma vez que não é possível acompanhar um único vaso ou ligações entre traqueídes, sendo os feixes bastante tortuosos. Seria necessário o uso de técnicas especiais para a avaliar se os elementos de vaso formam vasos em algumas espécies ou se são apenas responsáveis pela ligação dos demais elementos traqueais. Tais técnicas seriam a 
injeção de tinta utilizada em diversos trabalhos realizados principalmente com palmeiras por Zimmermann (197I, 1973, Zimmermann \& Tomlinson 1967, 1972, 1974, Zimmermann et al. 1974, 1982, Zimmermann \& Sperry 1983) ou através da infiltração e elaboração de molde dos elementos com resina realizada em madeiras (Fujii 1993, Kitin et al.200I). Resta a dúvida se a diferença de freqüência de elementos de vaso entre as espécies é significativa e se esta diferença poderia constituir um caráter diagnóstico de espécies ou gêneros, que só poderá ser resolvida através de estudos quantitativos.

A presença de traqueídes no caule das Velloziaceae pode estar relacionada ao fato de que todas as plantas desta família são revivescentes (Gaff 1977, Hallam \& Gaff 1978, Tuba et al. 1993, Porembski \& Barthlott 2000), isto é, são capazes de voltar à vida e produzir clorofila, mesmo depois de completamente secas, e que todas as espécies da família crescem sobre rochas em ambientes onde estão submetidas constantemente à estresse hídrico (Porembski \& Barthlott 2000). Este fenômeno é comum entre as criptógamas, mas é raro entre as Angiospermas (Tuba et al. 1993). A presença de traqueídes no caule oferece vantagens às plantas que sofrem estresses uma vez que são mais resistentes à cavitação e são preenchidas de água mais rapidamente do que elementos de vaso (Zimmermann 1983, Sperry 2003, Sperry et al. 2006).

Em 1983, Zimmermann \& Sperry demonstraram que os traços foliares de Rhapis excelsa (Arecaceae), na inserção da bainha com o caule, é composto apenas por elementos do protoxilema, ou seja traqueí- des de pequeno diâmetro, e elementos de vaso do metaxilema muito pequenos. De acordo com os autores, esta configuração é responsável por uma constrição hidráulica entre o caule e o pecíolo que é bastante útil para confinar a cavitação e subseqüentes falhas de condutividade em regiões acima do caule, garantindo assim, a integridade funcional deste órgão. Assim, em estresses hídricos, a cavitação ficaria restrita aos vasos de maior diâmetro do pecíolo. Sabe-se que, após estarem totalmente secas, as Velloziaceae iniciam a absorção de água pela folha e, só após as folhas retomarem a fotossíntese, é que as raízes passam a absorver água (Tuba et al. 1993). Sendo assim, quando as raízes iniciam a absorção e condução, a folha já iniciou a absorção de água, mas o caule ainda permanece seco, o que pode causar embolia e cavitação. Assim, as traqueídes presentes no caule, podem configurar um sistema vascular análogo ao dos traços foliares de Rhapis excelsa, atuando como uma região de constrição hídrica que, além de conduzir água mais rapidamente, confinaria possíveis bolhas de ar nas bainhas foliares. Além disso, a placa de perfuração escalariforme dos elementos de vaso foliares pode reter as bolhas de ar e evitar a cavitação.

Os elementos de vaso que ocorrem na folha das espécies de Velloziaceae analisadas são sempre longos, com placa de perfuração escalariforme com muitas barras e inclinada, bastante diferentes dos da raiz. Sendo assim, a hipótese gradista de Cheadle (1943A, 1943B), não é contestada em Velloziaceae. Nesta família, da mesma maneira que nas demais descritas por Cheadle, os elementos de vaso radiculares são mais especializados que os caulinares e estes, mais especiali- 
zados do que os foliares.Apesar disso, em uma das espécies que apresentou ausência de elementos de vaso no caule (Barbaceniopsis castillonii), são observados elementos de vaso na folha. Ayensu (1968) também chamou atenção para este mesmo fato em Barbaceniopsis boliviensis mas Menezes et al. (1990) detectaram a presença de elementos de vaso com placa de perfuração escalariforme nesta espécie. Como apenas um indivíduo de Barbaceniopsis castillonii foi analisado, não se pode concluir ao certo se esta espécie é uma exceção à hipótese de Cheadle.

Acanthochlamys bracteata foi a única espécie analisada, dentre as Velloziaceae e as espécies representantes do grupo externo, que não apresentou traqueídes no caule e, segundo análises cladísticas recentes de Pandanales (Rudall \& Bateman 2006), é a espécie basal da ordem. Se a hipótese de Cheadle for confrontada com as hipóteses evolutivas de Velloziaceae e Pandanales mais recentes (Mello-Silva 2005, Rudall \& Batemann 2006), tem-se que a espécie basal da família e da ordem (A. bracteata) possui elementos de vaso em todos os órgãos vegetativos. Já Triuridaceae, a última família a se diversificar em Pandanales, possui apenas traqueídes (elemento traqueal considerado primitivo pelos gradistas) em todos os órgãos analisados por Carlquist (1975). Além disso, Acantho- chlamys bracteata e a maioria das demais Velloziaceae analisadas possuem elementos de vaso com placa de perfuração simples no caule, enquanto que as espécies de Xerophyta analisadas e Pleurostima plantaginea apresentam placa de perfuração escalariforme nos elementos de vaso caulinares. Se otimizada no cladograma de Mello-Silva, tem-se que a condição plesiomórfica na família é a presença de placa de perfuração simples no caule. $O$ estado apomórfico seria placa de perfuração escalariforme com muitas barras,condição que também é considerada primitiva pelos gradistas. Assim, a tendência evolutiva observada por Cheadle em uma mesma espécie (elementos de vaso com características mais derivadas da raiz à folha) não pode ser aplicada em diferentes espécies de uma mesma família ou ordem. Deste modo, a presença de um determinado tipo de elemento traqueal e placa de perfuração parecem ser características muito mais adaptativas, do que uma tendência evolutiva.

Algumas características dos elementos traqueais dos órgãos vegetativos de Velloziaceae podem constituir caracteres informativos em análises cladísticas e serão incorporadas à matriz morfológica existente para a família. Além disso, tais características mostraram ser extremamente adaptadas às condições do ambiente que estas plantas ocupam. 


\section{Referências Bibliográficas}

AYENSU, E. S. 1968. The anatomy of Barbaceniopsis, a new genus recently described in the Velloziaceae. American Journal of Botany 55(4): 399-405.

BaAs, P., Wheeler, E. A. 1996. Parallelism and reversibility in xylem evolution. A review. IAWA Journal 17: 35I-364.

Bailey, I. W. 1944. The development of vessels in Angiosperms and its significance in morphological research. American Journal of Botany 31: 421-428.

BAiley, I.W., TuPPER, W.W. 1918. Size variation in tracheary cells. I. A comparison between the secondary xylems of vascular cryptogams, gymnosperms and angiosperms. Proceedings of the American Academy of Arts and Science 54: 149-204.

BUKATSCH, F. 1972. Bemerkungen zur doppelfärbung astrablau-safranin. Mikrokosmos 6I (8): 255.

Carlquist, S. 1975. Monocotyledons; Nymphaeales. In: Ecological strategies of xylem evolution. California University Press, Berkley, I04- 130.

CARLQUist, S. 1992. Wood anatomy and stem of Chloranthus; summary of wood anatomy of Chloranthaceae, with comments on relationships, vesselleness, and the origin of monocotyledons. IAWA Bulletin n.s. I3(I): 3-I6.

CARLQUIST, S. 1996. Wood anatomy of primitive angiosperms: new perspectives and syntheses. In: Taylor, D. W. \& Hickey, L. J. (eds). Flowering plant origin, evolution and phylogeny. Chapman \& Hall, New York, p. 68-90.

Carlquist, S., Schneider, E. L. 1997. Origins and nature of vessels in monocotyledons .I. Acorus. International Journal of Plant Sciences I58 (I): 5 I-56.

Carlquist, S., Schneider, E. L. 1998A. Origins and nature of vessels in Monotyledons. 3. Lowiaceae, with comments on rhizome anatomy. Blumea 43219-224.

CARlQuist, S., SCHNeider, E. L. 1998B. Origin and nature of vessels in monocotyledons. 5.Araceae subfamily Colocasioideae. Botanical Journal of the Linnean Society I28 (I): 7I-86.
Carlquist, S., Schneider, E. L 2006. Origins and nature of vessels in monocotyledons: 8 . Orchidaceae. American Journal of Botany 93 (7): 963-97I.

Chase, M.W., Soltis, D. E., Olmstead, R. G., Morgan, D., Les, D. H., Mishler, B. D., Duvall, M. R., Price, R. A. Hills, H. G., QIU,Y.-L., Kron, K.A., Rettig, J. D., Manhart, J. R., SYTSMA, K. J., Michaels, H. J., Kress, W. J., Karol, K. G., Clark, W. D., Hedrén, M., Gau, B. S., Jansen, R. K., Kim, K.-J.,Wimpee, C. F., Smith, J. F., Furnier, G. R., Strauss, S. H., Xiang, Q.Y., Plunkett, G. M., Soltis, P. S., Swensen, S. M., Williams, S. E., Gadek, P. A., Quinn, C. J., Eguiarte, L. E., Golenberg, E., Learn Jr., G. H., Graham, S. W., Barrett, S. C. H., Dayanandan, S., Albert, V.A. 1993. Phylogenetics of seed plants: an analysis of nucleotide sequences from the plastid gene rbcL.Annals of the Missouri Botanical Garden 80: 529-580.

Chase, M. W., Stevenson, D. W., Wilkin, P., Rudall, P. J. 1995. Monocot systematics: a combined analysis. In: Monocotyledons: systematic and evolution (P.J. Rudall, Cribb, P. J., Cutler, D. F., Humphries, C. J., ed). Royal Botanic Gardens, Kew, p. 685-730.

Cheade, V. I. 1942. The occurence and type of vessels in the varios organs of the plant in the Monocotyledonae. American Journal of Botany 29: 44 I-450.

Cheadle, V. I. 1943A. The origin and certain trends of specialization of the vessel in the Monocotyledonae. American Journal of Botany 30: I I- I7.

Cheadle, V. I. 1943B. Vessel specialization in the late metaxylem of the various organs in the monocotyledonae. American Journal of Botany 30: 484-490.

Cheadle, V. I. 1944. Specialization of vessels within the xylem of each organ in the Monocotyledoneae. American Journal of Botany 3 I (2): 8I-92.

Cheade, V. I. 1953A. Independent origin of vessels in the Monocotyledons and Dicotyledons. Phytomorphology 3:23-44. 
Cheadle, V. I. 1953B. The taxonomic use of specialization of vessels in the metaxilem of Gramineae, Cyperaceae, Juncaceae and Restionaceae. Journal of the Arnold Arboretum 36: |4|-|57.

Cheadle, V. I. 1968. Vessels in Haemodorales. Phytomorphology 18: 4I2-420.

Cheadle, V. I. 1969. Vessels in Amaryllidaceae and Tecophilaeaceae. Phytomorphology 19:8-16.

Cheadle, V. I. 1975. Vessels in Juncales: II. Centrolepidaceae and Restionaceae. American Journal of Botany 62(10): 1017-1026.

Cheadle, V. I., Kosakal, H. I97I. Vessels in Liliaceae. Phytomorphology 21 : 320-333.

Cheadle, V. I., Kosakal, H. 1972. Vessels in Cyperaceae. Botanical Gazette 133(3): 2 |4-223.

Davis, J. I., Stevenson, D.W., Petersen, G., Seberg, O., Campbell, L. M., Freudenstein, J.V., Goldman, D. H., Hardy, C. R., MIChelangeli, F.A., Simmons, M. P., Specht, C. D., Vergara-SilVA, F., GANDOLFO, M. 2004.A phylogeny of the monocots inferred from $r b c L$ and atpA sequence variation, and a comparison of methods for calculating jackknife and bootstrap values. Systematic Botany 29 (3): 467-5 10.

Donoghue M. J., DoYLE, J. A. 1989. Phylogenetic analysis of angiosperms and the relationships of Hamamelidae. Pp. 17-45 in: Crane, P. R., Brackmore, R. eds. Evolution, systematics, and fossil history of the Hamamelidae. Vol. I. Claredon, Oxford.

DOYLE, J. A., EndRESS, P. K. 2000. Morphological phylogenetic analysis of basal angiosperms: comparison and combination with molecular data. International Journal of Plant Sciences 16I: SI2I-SI53.

FAHN, A. 1954. Metaxylem elements in some families of the Monocotyledonae. New Phytologist 53(3): 530-540.

FrankLIN, G. L. 1945. Preparations of thin sections of synthetic resins and wood-resins composites, and a new macerating method for wood. Nature I55: 5 I.
Frost, F. H. 1930A. Specialization in secondary xylem in dicotyledons. I. Origin of vessel. Botanical Gazette 89: 67-94.

Frost, F. H. 1930B. Specialization in secondary xylem in dicotyledons. Il. Evolution of end wall of vessel segment. Botanical Gazette 89: 198-212.

Frost, F. H. 193I. Specialization in secondary xylem in dicotyedons. III. Specialization of lateral wall of vessel segment. Botanical Gazette 90: 88-96.

FujlI, T. 1993. Application of a resin casting method to wood anatomy of some japanese Fagaceae species. IAWA Journal 14:273-288.

GAFF, D. F. 1977. Dessication tolerant vascular plants of southern Africa. Oecologia 31: 95-109.

GerlaCh, D. 1984. Botanische Mikrotechnik. Georg Thieme Verlag, Stuttgart.

Hallam, N. D., GafF, D. F. 1978. Regeneration of chloroplast structure in Talbotia elegans: a desiccation-tolerant plant. New Phytologist 81: 657-662.

Kitin, P., SANo, Y, Funada, R. 200I. Analysis of cambium and differentiating vessel elements in Kalopanax pictus using resin cast replicas. IAWA Journal 22: I5-28.

KUBITZKI, J. G. 1998. Velloziaceae. In: Kubitzki, J. G., Huber, H., Rudall, P. J., Stevens, P. S., Stützel (eds.). The Families and Genera of Vascular Plants. III. Flowering plants - Monocotyledons. Lilianae (except Orchidaceae), 459-467. Springer-Verlag, Berlin.

Mello-Silva, R. 2000. Partial cladistic analysis of Vellozia and characters for the phylogeny of Velloziaceae. In K. L. Wilson, Morrison, D. A. [eds.], Monocots Systematic and Evolution, 505-522. CSIRO, Melbourne.

Mello-Silva, R. 2005. Morphological analysis, phylogenies and classification in Velloziaceae. Botanical Journal of the Linnean Society I48: I57-I73.

Menezes, N. L. 197I. New taxa and new combinations in Velloziaceae. Ciência e Cultura 23: 42 I-422. 
Menezes, N. L., Kameyama, C., Pires, F. R. S.,Assis, M. C., Bianchi, R. S., SouzA, V. C. 1990. O xilema de Velloziaceae e as relações entre os diferentes gêneros da família. XLI Congresso Nacional de Botânica, Universidade Federal do Ceará: 180.

Menezes, N. L., Mello-Silva, R., Mayo, S. J. 1994. A cladistic analysis of the Velloziaceae. Kew Bulletin 49: 7I-92.

POREMBSKI,S.. BARTHLOTT,W.2000. Granitic and gneissic outcrops (inselbergs) as centers of diversity for desiccation-tolerant vascular plants. Plant Ecology I5I (I): 19-28.

Rudall, P.J., Bateman, R. M. 2006. Morphological phylogenetic analysis of Pandanales: testing contrasting hypotesis of flora evolution. Systematic Botany 3 I (2): 223-238.

SChNeider, E. L., Carlquist, S. 1997. Origin and nature of vessels in monocotyledons. 2. Juncaginaceae and Scheuchzeriaceae. Nordic Journal of Botany 17:397-40I.

SChNeider, E. L., Carlquist, S. 1998. Origin and nature of vessels in monocotyledons. 4. Araceae subfamily Philodendroideae. Journal of the Torrey Botanical Society I25(4): 253-260.

Schneider, E. L., Carleuist, S. 2005A. Origin and nature of vessels in Monocotyledons. 6. Hanguana (Hanguanaceae). Pacific Science 59(3): 393-398.

Schneider, E. L., Carlquist, S. 2005B. Origin and nature of vessels in Monocotyledons. 7. Philydraceae and Haemodoraceae. Journal of the Torrey Botanical Society I 32(3): 377-383.

SPERRY, J. S. 2003. Evolution of water transport and xylem structure. International Journal of Plant Sciences 164(3) (Suppl.): SI I5-SI 27.

Sperry, J. S., Hacke, U. G., Pittermann, J. 2006. Size and function in conifer tracheids and angiosperms vessels. American Journal of Botany 93(I0): I490-I 500.

STERN,W. L. 1978.A retrospective view of comparative anatomy, phylogeny, and plant taxonomy. IAWA Bulletin 2-3.

Tuba, Z., Lichtenthaler, H. K., Csintalan, Z., Pócs, T. 1993.
Regreening of dessicated leaves of the poikilochlorophyllous Xerophyta scabrida upon rehydratation. Journal of Plant Physiology 142: 103-108.

YounG, D. A. 1981. Are the angiosperms primitively vesselless. Systematic Botany 6 (4): 31 3-330.

ZimmermanN, M. H. I 97I.Transport in the xylem. In: Zimmermann, M. H. \& Brown, C. L. (eds). Trees: structure and function. Springer-Verlag, New York, 169-219.

ZimmermanN, M. H.1973. The monocotyledons: their evolution and comparative biology. IV. Transport problems in arborescent monocotyledons. The Quarterly Review of Biology 483 |4-32I.

ZimmermanN, M. H. 1983. Xylem structure and the ascent of sap. Springer-Verlag, Berlin.

Zimmermann, M. H., Tomlinson, P. B. 1967. Anatomy of the palm Rhapis excelsa IV.Vascular development in apex of vegetative aerial axis and rhizome. Journal of The Arnold Arboretum 48I22-I42.

ZimmermanN, M. H., Tomlinson, P. B 1972. The vascular system of monocotyledonous stem. Botanical Gazette I 33 (2): |4|-|55.

ZimmermanN, M. H., TomLinson, P. B. 1 974.Vascular patterns in palm stems:Variations of the Rhapis principle. Journal of The Arnold Arboretum 55402-424.

ZimmermanN, M. H., Sperry, J. S. 1983. Anatomy of the palm Raphis excelsa. IX. Xylem structure of the leaf insertion. Journal Of The Arnold Arboretum 64599-609.

Zimmermann, M. H. \& Tomlinson, P. B., LeClaire, J. I 974. Vascular construction and development in the stems of certain Pandanaceae. Botanical Journal of the Linnean Society 682 I-4I.

Zimmermann, M. H., McCue, K. F., Sperry, J. S. 1982. Anatomy of the palm Rhapis excelsa, VIII. Vessel network and vessel-length distribution in the stem. Journal of The Arnold Arboretum 6383-95. 


\title{
Capítulo 2: \\ Novos CARACTERES ANATÔMICOS PARA \\ ANÁLISES FILOgenÉticAs em Velloziaceae
}

\author{
Marina Blanco Cattai, Renato de Mello-Silva \& Verônica Angyalossy
}

\section{Resumo}

Estudos anatômicos em Velloziaceae sempre foram importantes na delimitação de novas espécies, na classificação e em análises cladísticas da família. Caracteres caulinares e radiculares, contudo, não são incluídos em análises filogenéticas. Através do estudo de seções transversais e longitudinais de vinte e cinco espécies de Velloziaceae e três representantes do grupo externo, foram adicionados doze caracteres anatômicos à matriz morfológica já existente para a família, quatro referentes à análise do xilema e oito referentes ao córtex radicular e caulinar, secção transversal do caule, presença de feixe fibroso no caule e feixes vasculares caulinares.A análise obtida revelou que, dos doze caracteres analisados, seis constituem sinapomorfias de Velloziaceae incluindo Acanthochlamys bracteata: fibras no córtex radicular formando uma faixa contínua, fibras associadas aos feixes vasculares caulinares junto ao xilema, córtex caulinar dividido em três porções distintas, placa de perfuração simples nos elementos de vaso radiculares, presença de elementos de vaso no caule e presença de elementos de vaso na folha, sendo, as duas últimas, homoplásticas. Além disso, o caráter células com parede secundária na porção interna do córtex caulinar é sinapomorfia de (Nanuza Vellozia) e a presença de feixe fibroso central ao longo de todo o desenvolvimento caulinar é sinapomorfia de Vellozia s.s. A hipótese filogenética obtida sustenta a inclusão de A. bracteata em Velloziaceae, a delimitação de Barbacenia e Vellozia proposta por Mello-Silva, e a delimitação de Smith \& Ayensu para as subfamílias de Velloziaceae s.s.

Palavras-Chave: Velloziaceae, anatomia radicular e caulinar, Acanthochlamys bracteata, filogenia.

\section{Abstract}

Anatomical studies have always been important to the delimitation of new species, classification and cladistic analyses of Velloziaceae. However, root and stem features are not well known and have not been included in phylogenetic analyses. Transverse and longitudinal sections of 25 Velloziaceae and three outgroup species were used to add 12 characters to the existing morphological matrix of Velloziaceae: four regarding the xylem and eight regarding the root and stem anatomy (root and stem cortex, stem transverse section, presence of a fibrous bundle in the stem and stem vascular bundles). The analysis showed that six of the 12 characters are synapomorphies for Velloziaceae including Acanthochlamys bracteata: belt of continuous fibers in the root cortex, fibers in the stem vascular bundles within the xylem, stem cortex divided into three regions, simple perforation plates in root vessel elements and presence of vessel elements in the stem and leaves; the last two are homoplastic. Moreover, secondary cell walls in the inner portion of the stem are a synapomorphy for the Nanuza-Vellozia clade while the presence of a central fibrous bundle in the stem is a synapomorphy of Vellozia s.s. The phylogenetic hypothesis presented here supports the inclusion of A. bracteata in Velloziaceae, Mello-Silva's delimitation of Barbacenia and Vellozia and the subfamily delimitation of Smith \& Ayensu.

KeY Words: Velloziaceae, root and stem anatomy, Acanthochlamys bracteata, phylogeny. 


\section{INTRODUÇÃo}

A moderna taxonomia de Velloziaceae iniciouse com Smith \& Ayensu (Smith 1962, Smith \& Ayensu 1974, 1976,) e Menezes (197/A) que descreveram e redelimitaram gêneros na família. A grande diferença entre os dois sistemas de classificação está nos caracteres priorizados por cada autor (Mello-Silva I99/A). Enquanto Smith \& Ayensu priorizam a morfologia do estigma e filete e a posição dos apêndices florais em relação aos filetes, Menezes dá maior importância à presença ou ausência de corona e à constituição das bainhas dos feixes, para a delimitação das duas subfamílias propostas para Velloziaceae.

Ao todo, foram descritos nove gêneros para Velloziaceae, mas cada sistema de classificação aceita apenas seis. Menezes (197/A) foi a primeira a separar Velloziaceae em duas subfamílias: Vellozioideae composta por Vellozia e Xerophyta e Barbacenioideae, composta por Aylthonia, Barbacenia, Burlemarxia e Pleurostima. Smith \& Ayensu (1974, 1976), aceitam as subfamílias propostas por Menezes (197/A) mas as delimitam de maneira distinta estanto Vellozioideae composta por Nanuza e Vellozia e Barbacenioideae por Barbacenia, Barbaceniopsis, Talbotia e Xerophyta.

Em análises cladísticas de Velloziaceae (Menezes et al. 1994, Mello-Silva 2000, 2005, Behnke et al. 2000, Salatino et al. 200I) apenas Barbacenioideae sensu Menezes emerge monofilética. Já análises filogenéticas realizadas para as angiospermas e para as monocotiledôneas (Chase et al. 1993, 1995, 2006) apontam que Acanthochlamys, um gênero monotipico chinês, é o grupo irmão de Velloziaceae e o inclui na família (Chase et al. 1993, 1995).

Na última proposta de classificação para Velloziaceae, Mello-Silva (2005) aceita cinco gêneros para a família, baseado no monofiletismo dos grupos (Acanthochlamys, Barbacenia, Vellozia, Talbotia e Xerophyta) e não propõe uma nova delimitaçao para as subfamílias uma vez que a filogenia ainda não é bem resolvida e sustentada.

Estudos anatômicos em Velloziaceae iniciaramse com Warming (1893) que descreveu a anatomia foliar de diversas espécies. Posteriormente, Holm (1895) faz uma breve descrição anatômica de Vellozia e Barbacenia, mas os estudos anatômicos na família só se intensificaram a partir dos trabalhos de Ayensu que, em 1968 descreveu o gênero Barbaceniopsis e a anatomia de seus órgãos vegetativos. Posteriormente, o autor realizou estudos com anatomia foliar de diversas espécies de Velloziaceae, sendo os primeiros (Ayensu I969A e 1969B) referentes à espécies africanas e, o mais extenso (Ayensu 1974), dedicado às espécies americanas.

Menezes (197/ В, 1975), por sua vez, estudou a morfogênese caulinar no intuito de avaliar a saída dos traços foliares constatando que nestes, assim como nos feixes foliares, ocorre a presença de traqueídes de transfusão, tanto nas espécies de Vellozioideae quanto nas de Barbacenioideae. Menezes (1973) verificou ain- 
da, que os apêndices petalóides presentes nas espécies de Barbacenioideae possuem origem relacionada ao perigônio, constituindo uma corona. A anatomia floral também foi avaliada pela autora em outros estudos visando analisar a megasporogênese, megagametogênese e embriogênese, a corona e evolução da antera na família (Menezes 1976, 1980a, 1988, Menezes \& Semir, 1990, Menezes \& Castro 2000). A anatomia do pedicelo foi utilizada por Mello-Silva (2000) em análise cladística do gênero Vellozia e, a forma da secção transversal do pedicelo, o número de feixes vasculares e a presença de células esclerificadas constituem caracteres informativos no gênero.

A importância dos caracteres anatômicos em Velloziaceae fica evidenciada na delimitação das subfamílias proposta por Menezes (197/A, I980B, 1988) e Smith \& Ayensu (1974, 1976). Além disso, a análise da anatomia foliar é extensamente utilizada na delimitação taxonômica em nível genérico e específico (Menezes \& Semir I99I, Mello-Silva I99IB, Mello-Silva \& Menezes 1999, McPherson et al. 1997, Alves 2002), e abordagens filogenéticas (Menezes et al., 1994, Mello-Silva 2000, 2005). Tipo e distribuição do complexo estomático,

\section{Material e Métodos}

Foram analisados de um a três indivíduos de 25 espécies de Velloziaceae e 3 representantes do grupo externo (Tabela I). Todas as espécies analisadas estão presentes na análise cladística apresentada por Mello-Silva (2005). Desta forma, tem-se uma matriz morfológica de base onde novos caracteres po- presença de células especializadas (maiores que as células vizinhas) na face adaxial da folha, organização do parênquima aqüífero, presença de vasos na folha e reentrâncias na lâmina foliar são alguns dos caracteres apontados por Mello-Silva $(2000,2005)$ como informativos em análises cladísticas da família.

Apesar dos estudos em anatomia foliar e floral, existem poucas informações sobre a anatomia dos demais órgãos de Velloziaceae.Ayensu (1968) descreve a anatomia da raiz e caule de Barbaceniopsis e Porembski \& Barthlott (1995) que demonstram a ocorrência de velame nos gêneros Vellozia e Xerophyta. Menezes (I97/ B, I975) utiliza a anatomia caulinar para provar a presença das traqueídes de transfusão.

Devido a relevância dos caracteres anatômicos foliares em análises cladísitcas e na compreensão da história evolutiva da família, o objetivo deste trabaIho é analisar a anatomia da raiz e do caule de espécies de Velloziaceae em busca de caracteres ainda não empregados em análises filogenéticas. Busca-se, ainda, verificar possíveis hipóteses de homologia primária destes caracteres na família.

dem ser testados. Além disso, as espécies analisadas abrangem todos os gêneros já descritos para a família. Secções transversais do caule e raiz foram utilizadas para o levantamento de caracteres. Em alguns dos caracteres analisados através das secções transversais e longitudinais dúvidas surgiram, em relação à homo- 
Tabela I: Lista das espécies analisadas, respectivos vouchers e número de espécimes analisados. As espécies em negrito são as utilizadas para o estudo da morfogênese caulinar e as com asterisco são as que foram obtidas a partir de material herborizado

\begin{tabular}{|c|c|c|c|}
\hline ESPÉCIE & FAMÍLIA & VOUCHER & EsP. \\
\hline Acanthochlamys bracteata* P.C. Kao & Velloziaceae & Kao s.n. & I \\
\hline Aylthonia umbrosa (L. B. Sm. \& Ayensu) & Velloziaceae & $\begin{array}{l}\text { Harley CFCR } 6477 \\
\text { Mello-Silva CFCR6477 }\end{array}$ & 2 \\
\hline Barbacenia ignea Mart. & Velloziaceae & Mello-Silva 2554 & I \\
\hline Barbacenia reflexa L. B. Sm. \& Ayensu & Velloziaceae & Mello-Silva CFCR 10793 & I \\
\hline Barbaceniopsis castillonii* (Hauman) lbisch & Velloziaceae & Mello-Silva 1857 & I \\
\hline Burlemarxia spiralis (L.B.Sm. \& Ayensu) N.L.Menezes \& J.Semir & Velloziaceae & Mello-Silva 2548 & 3 \\
\hline Nanuza plicata (Mart.) L. B Sm. \& Ayensu & Velloziaceae & $\begin{array}{l}\text { Cattai } 01 \\
\text { Cattai } 02\end{array}$ & 3 \\
\hline Pleurostima longiscapa (Goethart \& Henrard) N. L. Menezes & Velloziaceae & $\begin{array}{l}\text { Mello-Silva } 1776 \\
\text { Mello-Silva } 2553\end{array}$ & 2 \\
\hline Pleurostima plantaginea (L. B. Sm.) & Velloziaceae & Salatino CFCR II90I & I \\
\hline Pleurostima riparia N. L. Menezes \& Mello-Silva & Velloziaceae & Menezes II67 & 3 \\
\hline Talbotia elegans Balf. & Velloziaceae & $x x-0-B O N N-764$ & I \\
\hline Vellozia abietina Mart. & Velloziaceae & $\begin{array}{l}\text { Mello-Silva } 1777 \\
\text { Mello-Silva } 2673\end{array}$ & 3 \\
\hline Vellozia alata L. B. Sm. & Velloziaceae & Mello-Silva 2368 & 2 \\
\hline Vellozia albiflora Pohl & Velloziaceae & $\begin{array}{l}\text { Menezes } 528 \\
\text { Mello-Silva } 2132\end{array}$ & 2 \\
\hline Vellozia burlemarxii L. B. Sm. \& Ayensu & Velloziaceae & Mello-Silva 2148 & $\mathrm{I}$ \\
\hline Vellozia caudata Mello-Silva & Velloziaceae & Mello-Silva 2132 & I \\
\hline Vellozia hemisphaerica Seub. & Velloziaceae & $\begin{array}{l}\text { Mello-Silva } 2576 \\
\text { Mello-Silva } 2800 \\
\text { Mello-Silva } 2828\end{array}$ & 3 \\
\hline Vellozia hirsuta Goethart \& Henrard & Velloziaceae & $\begin{array}{l}\text { Mello-Silva } 2576 \\
\text { Mello-Silva } 2698\end{array}$ & 2 \\
\hline Vellozia jolyi L. B. Sm. & Velloziaceae & $\begin{array}{l}\text { Mello-Silva } 2145 \\
\text { Mello-Silva } 2146\end{array}$ & 2 \\
\hline Vellozia minima Pohl & Velloziaceae & Mello-Silva 2666 & 3 \\
\hline Vellozia prolifera Mello-Silva & Velloziaceae & Mello-Silva 2560 & 3 \\
\hline Vellozia punctulata Seub. & Velloziaceae & Mello-Silva 2587 & I \\
\hline Xerophyta dasylirioides* Baker & Velloziaceae & Puy 176 & I \\
\hline Xerophyta eglandulosa* Baker & Velloziaceae & Puy 169 & I \\
\hline Xerophyta pinifolia* Lam. & Velloziaceae & Puy 167 & I \\
\hline Encholirium scrutor (L. B. Sm.) Rauh & Bromeliaceae & Forzza 1488 & 2 \\
\hline Pandanus racemosus Kurz & Pandanaceae & Pirani 4755 & 3 \\
\hline Thoracocarpus bissectus (Vell.) Harling & Cyclanthaceae & Fiaschi \& Lobão 533 & 3 \\
\hline
\end{tabular}

logia primária e para que estas dúvidas pudessem ser sanadas, realizou-se o estudo da morfogênese caulinar em II espécies.

Devido às condições ecológicas em que as plantas se desenvolvem, optou-se por fixar e armazenar o material coletado em uma solução aquosa, para que fosse gradativamente reidratado e os tecidos se mantivessem intactos. Como não havia disponível na literatura um fixador aquoso, testou-se uma solução de água destilada e glicerina ( $1:$ Iv/v) e formaldeído 10\%, obtendo-se resultados satisfatórios. O levantamento de caracteres foi realizado a partir de secções transversais de caules e raízes adultas.As raízes adventícias de todas as espécies de Velloziaceae crescem entre o caule e as bainhas foliares (figura I) e, assim, ao serem realizadas as secções transversais caulinares, são realizadas também, secções transversais das raízes (figura 2). 


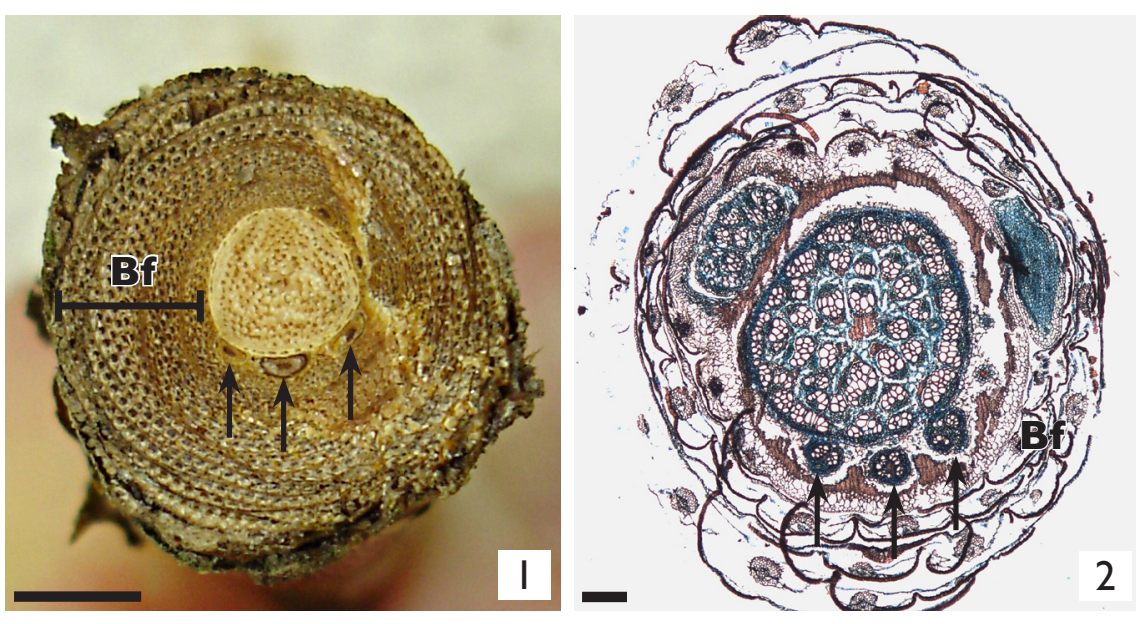

I: Caule de Vellozia declinans evidenciando as bainhas foliares (Bf) e as raízes que crescem entre as bainhas e o caule (setas). 2: Caule de Vellozia minima onde se observam raízes no córtex, qeu sairão do caule (setas). rofórmio. Após a substituição do etanol $100 \%$ por clorofórmio, o material foi fervido em clorofórmio por 12 horas e submetido à infiltração em parafina. A infiltração seguiu o seguinte protocolo:

I) Amolecimento em água e glicerina $(\mathrm{I}: \mathrm{I} \mathrm{v} / \mathrm{v})$ - banho-maria à $80^{\circ} \mathrm{C}$ por 6 horas

2) Desidratação: trocas de $12 \mathrm{em}$ 12 horas - Etanol 10\%, 20\%, 30\%,
Por ser um material que apresenta muito parênquima e fibras, as porções caulinares e radiculares pós-fixadas foram infiltradas e incluídas em polietilenoglicol (PEG) I500, segundo Gerlach (1984). Posteriormente, o material foi seccionado em micrótomo de deslize, corados com azul de astra $1 \%$ em etanol $50 \%$ e safranina I\% em etanol 50\% (Bukatsch 1972), desidratados e montados em resina sintética. $O$ material herborizado foi previamente reidratado com água e glicerina $(I: I \mathrm{v} / \mathrm{v})$ para que fosse submetido às técnicas descritas acima. Para os estudos do desenvolvimento caulinar, porções de raízes e caules adultos e seus ápices foram infiltrados em parafina e seccionados em série.

Para a infiltração em parafina, porções caulinares foram amolecidas em uma solução de água e glicerina $(\mathrm{I}: \mathrm{I} \mathrm{v} / \mathrm{v})$ em banho-maria à $80^{\circ} \mathrm{C}$ por 6 horas. Posteriormente o material foi desidratado em série etanolica até etanol $100 \%$. Foram testados diversos solventes para a infiltração: butanol, clorofórmio, toluol e xilol e o melhor resultado foi obtido com clo-
$40 \%, 50 \%, 60 \%, 70 \%, 80 \%, 90 \%, 100 \%$

3) Clorofórmio I:3 Etanol 100\% - 48 horas

4) Clorofórmio I:I Etanol 100\% - 48 horas

5) Clorofórmio 3:I Etanol 100\% - 48 horas

6) Clorofórmio P.A. - 48 Horas

7) Fervura do material em clorofórmio por 12 horas

8) Clorofórmio 3:I Parafina - Em estufa $60^{\circ} \mathrm{C}$ - $48 \mathrm{~h}$

9) Clorofórmio I:I Parafina - Em estufa $60^{\circ} \mathrm{C}$ - $48 \mathrm{~h}$

10) Clorofórmio I:3 Parafina - Em estufa $60^{\circ} \mathrm{C}$ - $48 \mathrm{~h}$

II) Parafina $100 \%$ - Em estufa $60^{\circ} \mathrm{C}$ - uma semana

Apos a infiltração, o material foi seccionado em micrótomo rotativo, corado com azul de astra $1 \%$ em etanol $50 \%$ e safranina $1 \%$ em etanol $50 \%$ (Bukatsch 1972) e montados em lâminas permanentes. A observação do material foi realizada sob microscopia de luz e os resultados documentados em fotomicroscópio.

Após a determinação dos caracteres, estes foram adicionados, juntamente com os caracteres referentes aos elementos traqueais observados no capí- 
tulo I à matriz morfológica elaborada por Mello-Silva et al. (in prep.), contituída de 77 caracteres. Neste capítulo, os caracteres descritos estão numerados de I a 8 e, assim, os caracteres informativos para o xilema descritos no capítulo I estão numerados de 9 a 12:

9 - Tipo de placa de perfuração dos elementos de vaso radiculares

10 - Elemento de vaso no caule

I I -Tipo de placa de perfuração dos elementos de vaso caulinares

12 - Elemento de vaso na folha

As análises cladísticas foram efetuadas utilizando o algorítimo PAUP para Macintosh (Phylogenetic

\section{Resultados}

A análise das secções transversais da raiz e do caule de espécies de Velloziaceae revelou resultados que podem ser utilizados em análises filogenéticas da família e possivelmente, da ordem Pandanales. Os caracteres observados estão descritos a seguir.

\section{RAIZ}

Exceto em Acanthochlamys bracteata, que possui um protostelo muito simples, apresentando apenas dois a quatro pólos de protoxilema (figura 3), as raízes de Velloziaceae possuem de oito a I 5 pólos de protoxilema e a medula apresenta-se lignificada (figura 4). As raízes das espécies de Velloziaceae estudadas são morfologicamente similares. No entanto, alguns dos
Analysis Using Parcimony, version 4.0 beta) (Swofford 2002). $O$ enraizamento da árvore foi em Encholirium scrutor (Bromeliaceae) e Pandanus racemosus/Thoracocarpus bissectus (Pandaneceae/Cyclanthaceae), segundo diretrizes de Farris (1982), Nixon \& Carpenter (1993) e Ferrarezzi \& Marques (1997). Realizou-se análise de parcimônia e os caracteres não foram ordenados e não tiveram pesos diferentes.A consistência do monofiletismo dos ramos no cladograma foi avaliada através de "bootstrap" com dez mil replicações (Felsenstein 1985) e valores maiores do que $50 \%$ estão expressos nos resultados. O programa MacClade 4.0 (Maddison \& Maddison 2000) foi utilizado para a elaboração da matriz e na análise da evolução dos caracteres.

caracteres analisados podem ser informativos em relação ao grupo externo.

\section{I - Porção mediana do córtex radicular formada por uma faixa contínua de fibras: ausente-0; presente-I}

O córtex radicular de Velloziaceae é composto por três porções distintas (figuras 3 e 4): a porção interna, composta por células parenquimáticas, a porção mediana, formada por uma faixa contínua de fibras e a porção externa que se assemelha a um velame.A porção externa do córtex já foi descrita como velame por Menezes \& Giulietti (1986) e Porembski 
\& Barthlott (1995). O velame é uma epiderme multisseriada (Evert 2006) e foi observado principalmente em Orchidaceae (Dycus \& Knudson 1957, Benzig et al. 1982). Em Velloziaceae, contudo, através do estudo de secções seriadas de ápices radiculares e raízes em diferenciação, é possível observar que esta região do córtex não constitui um velame, pois sua origem não é epidérmica. Na figura 5 é possível observar o ápice radicular de Vellozia burlemarxii com a epiderme com células mais alongadas e a camada precursora da hipoderme com células em divisão. Em Talbotia elegans (figuras 6 e 7) se observa a epiderme com pelos radiculares (figura 6) e a hipoderme em divisão (figura 7). Em Vellozia hemisphaerica fica evidenciada a epiderme, constituída de células justapostas e menores que as da hipoderme, a hipoderme multisseriada com células maiores e as demais e células parenquimáticas, constituindo a porção externa do córtex (figura 8). Sendo assim, a porção externa do córtex é formada por células derivadas exclusivamente do meristema fundamental e, portanto, não constitui um velame.

A denominação córtex externo foi utilizada porTomlinson (1969) para descrever uma região semeIhante no córtex radicular de Bromeliaceae.Tomlinson (1969) descreveu esta região como sendo constituída pela exoderme estratificada e demais células corticais. Pita \& Menezes (2002), por sua vez, descreveram esta região como sendo um velame em espécies de Dyckia e Encholirium (porém não utilizaram E. scrutor). Através das secções transversais radiculares de Encholirium scrutor (figuras 10 e II) não foi possível verificar a origem epidérmica da porção externa do córtex nem cé- lulas epidérmicas estratificadas. Adotou-se portanto, a definição de Tomlinson (1969) para a região externa do córtex radicular e, desta forma, E. scrutor possui, assim como as Velloziaceae, uma faixa contínua de fibras na porção mediana do córtex radicular. Nas demais espécies representantes do grupo externo, são observadas fibras dispersas no córtex radicular (figura 9).

\section{Caule}

\section{2 - Secção transversal do caule adulto: cir- cular-0; triangular-I}

Assim como a secção transversal do pedicelo (Mello-Silva 2005), a secção transversal do caule de Velloziaceae pode ser circular (figura I3) ou triangular (figura I5). Este caráter deve ser observado no caule adulto uma vez que, quando em formação (figuras 12 e 14), caules que são proeminentemente triangulares quando adultos, não apresentam este formato evidente (figura 14). A forma da secção transversal do pedicelo (Mello-Silva 2005) é independente da forma da secção transversal do caule, uma vez que plantas com caule triangular podem apresentar pedicelo circular e vice-versa.

\section{3 - Fibras corticais caulinares: ausentes-0; formando cordões-I; formando uma faixa contínua-2}

O córtex caulinar de Velloziaceae apresenta fibras que podem formar cordões como em Vellozia hemisphaerica (figuras 16 a 19), ou uma faixa contínua 

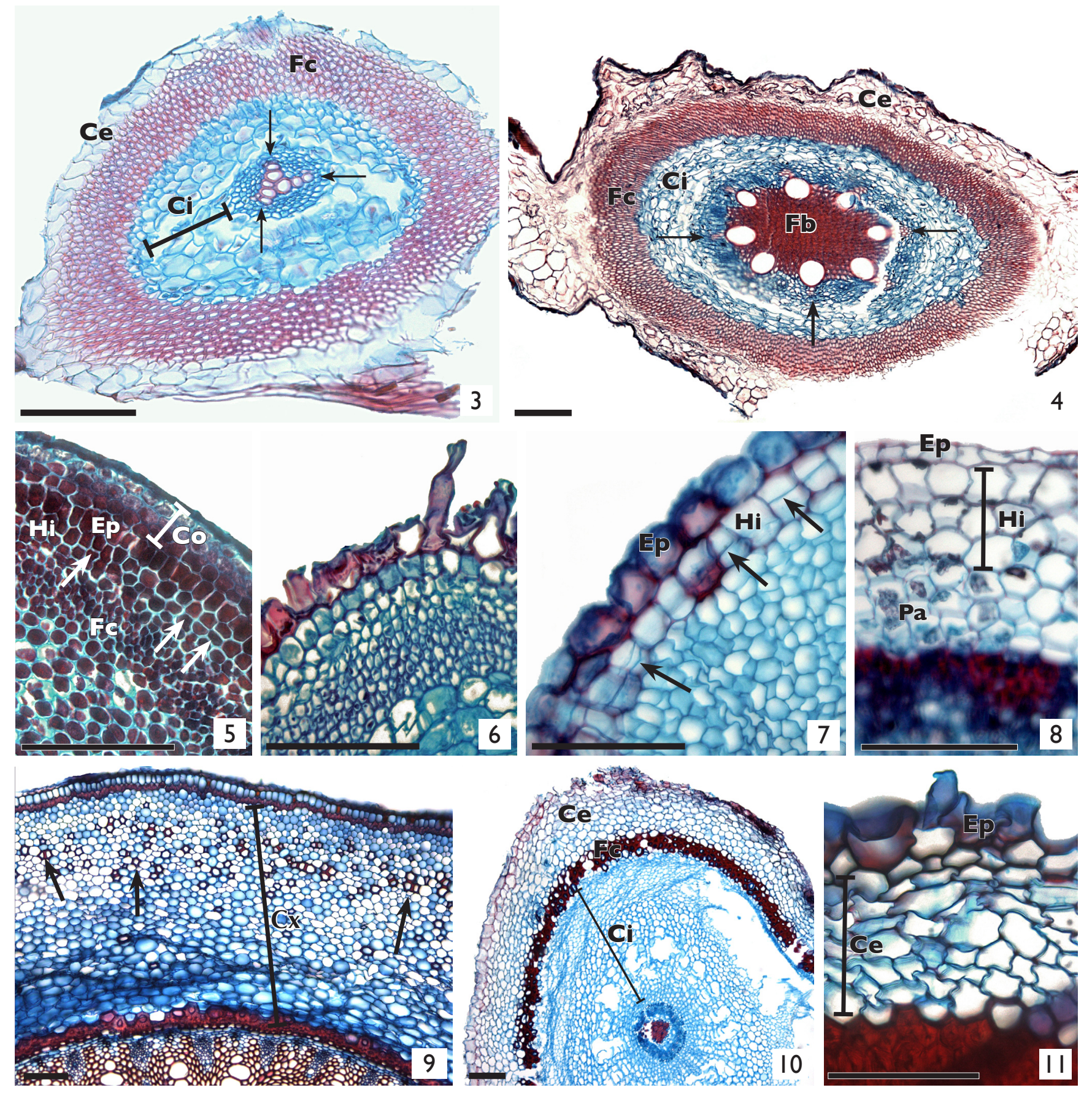

Figuras 3 a 6: Raízes de Velloziaceae em secção transversal. 3: Raiz de Ancanthochlamys bracteata adulta, onde se observa o córtex externo $(\mathrm{Ce})$, fibras corticais formando uma faixa contínua $(\mathrm{Fc})$, o córtex interno $(\mathrm{Ci})$ e três pólos de protoxilema (setas). 4: Raiz de Barbaceniopsis castillonii onde se observa a presença de um córtex externo (Ce), fibras corticais ( $\mathrm{Fc}$ ), córtex interno $(\mathrm{Ci})$, medula lignificada $(\mathrm{Fb})$ e oito pólos de protoxilema (setas).5: Região apical da raiz de Vellozia burlemarxii onde se observa, de fora para dentro, a coifa (Co), a epiderme (Ep), a hipoderme ( $\mathrm{Hi})$ com células em divisão (setas) e células menores, precursoras das fibras corticais ( $\mathrm{Fc}$ ). 6: Raiz de Talbotia elegans onde se observa a epiderme com pelos radiculares. 7: Raiz de Talbotia elegans evidenciando a epiderme (Ep) e as células da hipoderme ( $\mathrm{Hi})$ em divisão (setas). 8: Secção a Imm do ápice da raiz de de Vellozia hemisphaerica onde é possível observar que o córtex externo, que posteriormente se torna lignificado, é composto pela epiderme (Ep), hipoderme multisseriada $(\mathrm{Hi})$ e células parenquimáticas $(\mathrm{Pa})$. Figuras 9 a I I: Raízes de espécies representantes do grupo externo. 9: Raiz de Thoracocarpus bissectus onde se observa o córtex (Cx) parenquimático e fibras dispersas (setas). 10 e I I: Raiz de Encholirium scrutor. I0: Secção transversal onde se observa o córtex radicular, cuja disposição dos tecidos é semelhante à de Velloziaceae. I I: Detalhe da porção externa do córtex $(\mathrm{Ce})$ evidenciando a epiderme (Ep), a hipoderme (Hi), constituída de células menores e hexagonais e demais células parenquimáticas. Barra $=100 \mu \mathrm{m}$. 


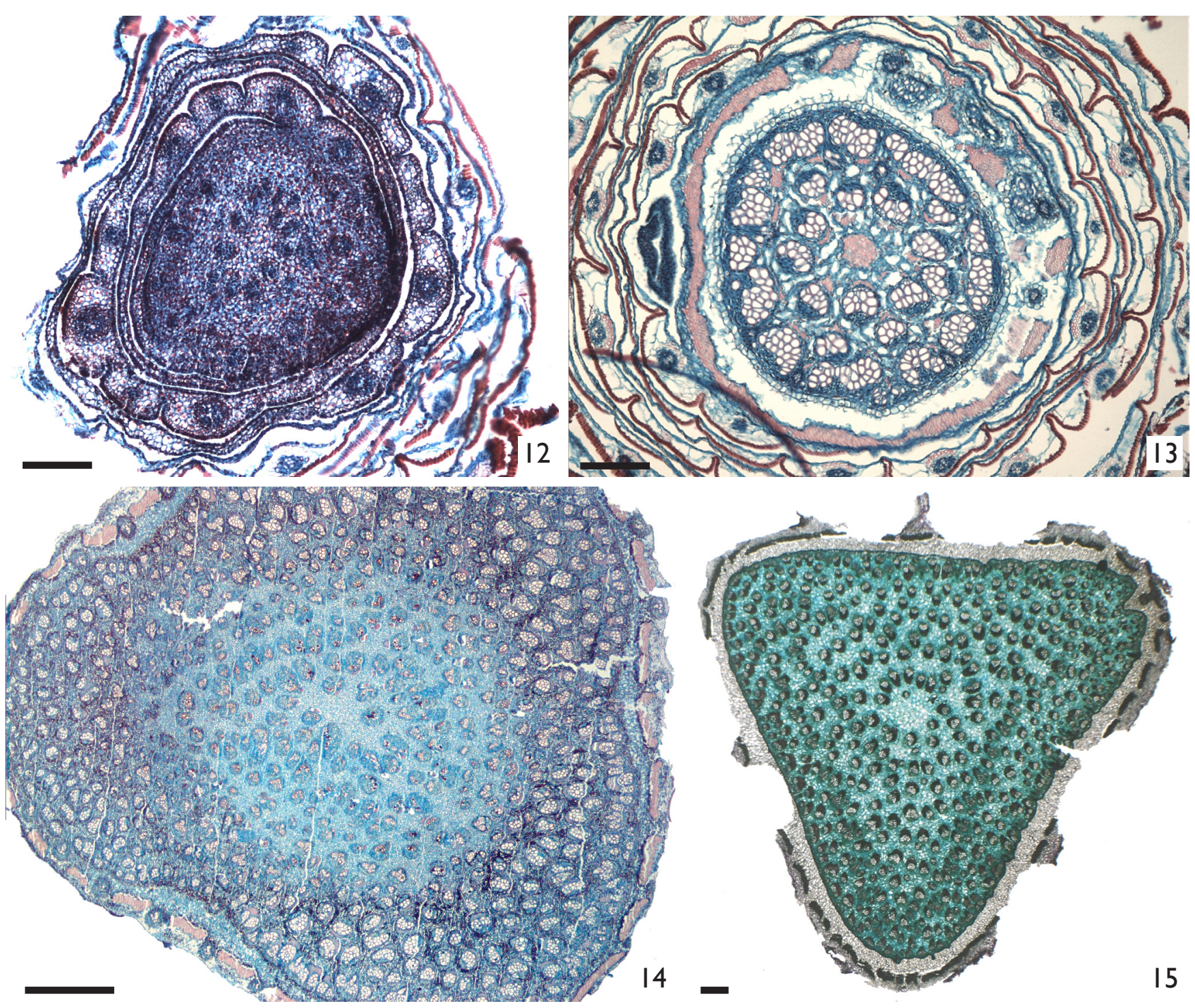

Figuras I 2 a I5: Secção transversal do caule. I 2 e I3: Vellozia minima evidenciando a secção circular no início do desenvolvimento caulinar (figura I2) e no caule já completamente diferenciado (figura I3). I4 e I 5: Caule de Nanuza plicata onde é possível observar que o formato triangular não é tão evidente no caule em formação (figura I4) quanto no caule adulto (figura I5). Figuras II e I2, Barra $=100 \mu \mathrm{m}$. Figuras I3 e I4, Barra $=500 \mu \mathrm{m}$.

como em Burlemarxia spiralis (figuras 22 a 29). As fibras em calotas mantêm-se durante todo o desenvolvimento caulinar, independentemente da saída de traços foliares (figura 18). As células entre as calotas são inicialmente parenquimáticas (figura 18) e se lignificam posteriormente, sem formar fibras, mesmo quando não há saída de traços foliares (figura 19). Nas espé- cies onde as fibras corticais formam uma faixa contínua (figuras 22 a 29), ela pode ser observada desde o início do desenvolvimento. Mesmo antes das fibras estarem lignificadas, podem ser observadas, no córtex, células de menor diâmetro que, posteriormente, formarão a faixa de fibras (figuras 23 e 24). $O$ processo de deposição de parede secundária e lignificação das 

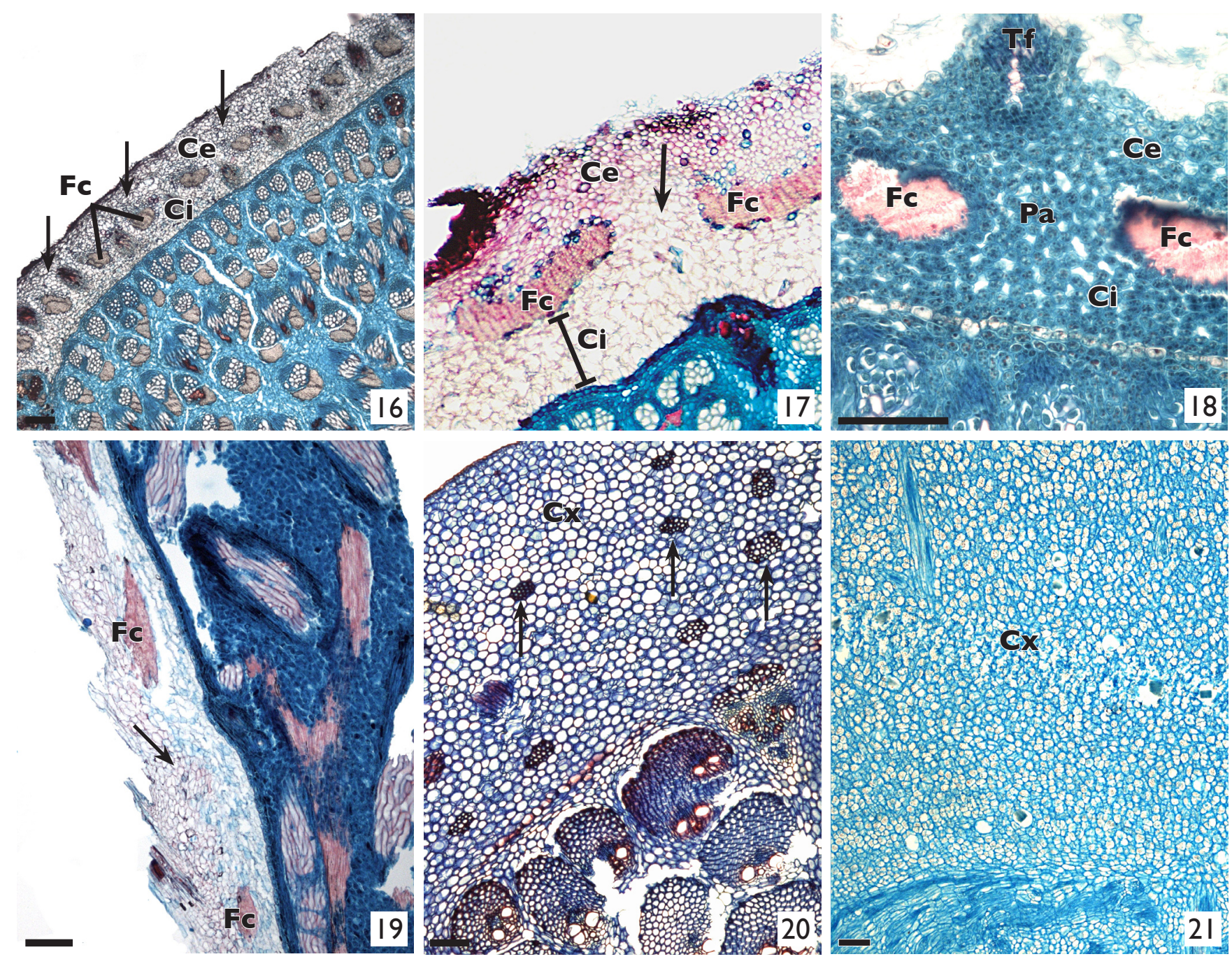

Figuras 16 a 21 : Fibras corticais caulinares e córtex caulinar. 16 a 19: Vellozia hemisphaerica. 16 e I7: Secção transversal do caule evidenciando a presença de calotas de fibras (setas) e córtex dividido em córtex externo $(\mathrm{Ce})$, fibras corticais $(\mathrm{Fc})$ e córtex interno $(\mathrm{Ci})$. I 8: Secção transversal do caule jovem evidenciando a saída de um traço foliar ( $\mathrm{Tf})$, a presença de parênquima $(\mathrm{Pa})$ entre as calotas de fibras $(\mathrm{Fc})$ e os córtex externo e interno, ambos constituídos de células parenquimáticas nesta fase do desenvolvimento. 19: Secção longitudinal evidenciando a presença de fibras em calotas ( $\mathrm{Fc}$ ) e células esclerificadas entre as calotas (setas). 20: Caule de Pandanus racemosus (fig. 20) evidenciando a presença de calotas de fibra (setas) que não separam o córtex em três regiões distintas. 2 I: Caule de Encholirium scrutor que possui e córtex parenquimático (Cx). Barra $=100 \mu m$.

fibras pode ser observado nas figuras 24 a 27.

A saída dos traços foliares, que atravessam a faixa contínua de fibras, não quebra a integridade da faixa, que volta a se lignificar (figura 26).A faixa contínua de fibras e a saída do traço foliar também podem ser observadas em secções longitudinais (figuras 28 e 29).

No grupo externo, Thoracocarpus bisectus e Pandanus racemosus (figura 20) apresentam fibras em calotas e Encholirium scrutor não apresenta fibras no córtex (figura 2l). 


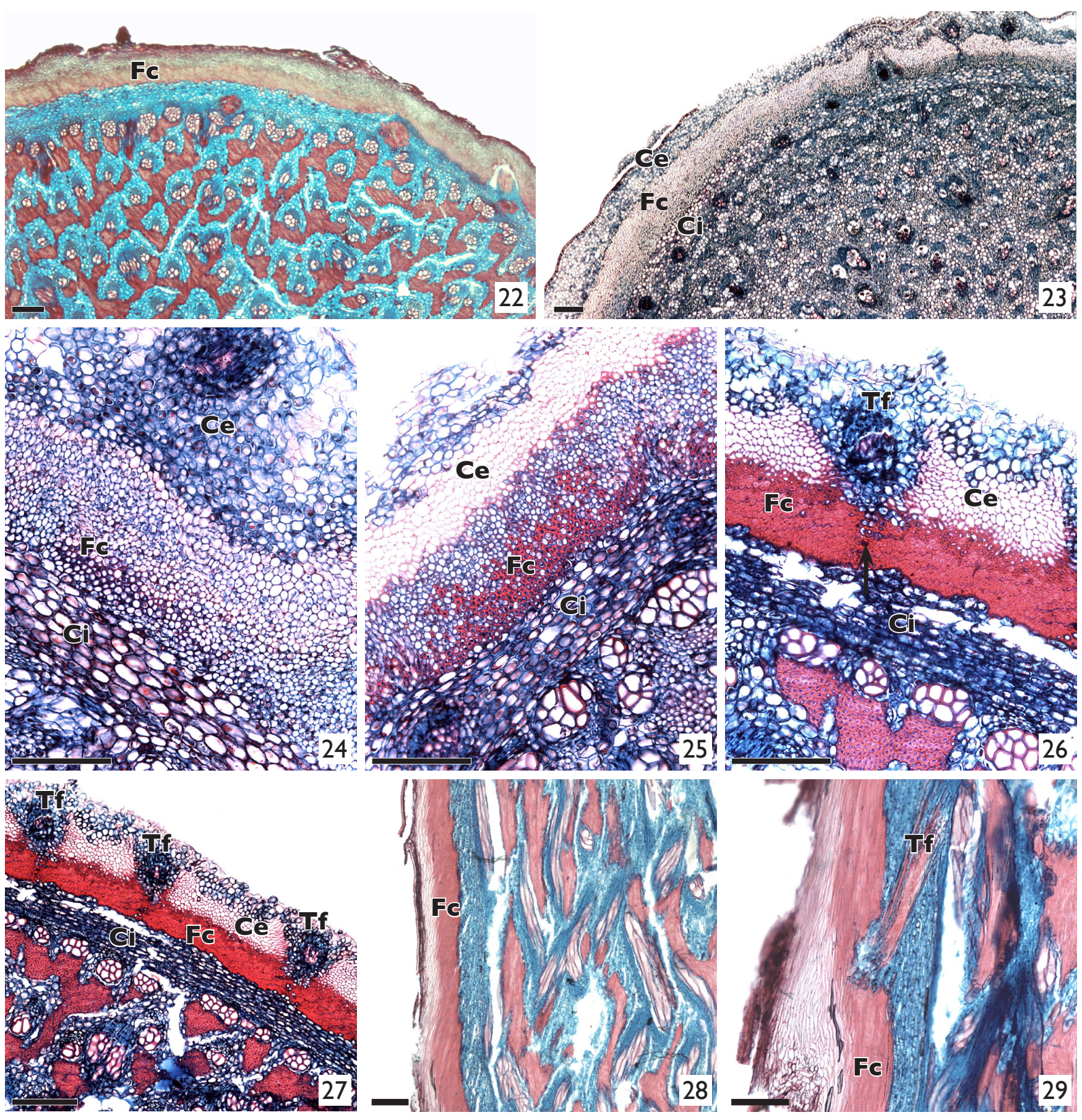

Figuras 22 a 29: Fibras corticais caulinares de Burlemarxia spiralis. 22: Secção transversal do caule adulto evidenciando as fibras corticais $(\mathrm{Fc})$ formando uma faixa contínua. 23 e 24: Caule jovem onde já é possível observar as células precursoras das fibras corticais $(\mathrm{Fc})$ e os córtex externo e interno com células parenquimáticas. 25: Estágio do desenvolvimento caulinar onde as fibras corticais já começam a se diferenciar, formando paredes espessas e as células parenquimáticas do córtex externo que também se espessam $(\mathrm{Ce})$; o córtex interno $(\mathrm{Ci})$ permanece parenquimático. 26: Saída de um traço foliar (Tf) onde se observa que, após a saída do traço, novas fibras são formadas no córtex para a manutenção da faixa contínua de fibras $(\mathrm{Fc})$. 27: Caule adulto onde se observa a faixa contínua de fibras $(\mathrm{Fc})$, mesmo com a saída de muitos traços foliares $(\mathrm{Tf})$, córtex externo lignificado $(\mathrm{Ce})$ e córtex interno parenquimático (Ci). 28 e 29: Secção longitudinal do caule onde também é possível observar a faixa contínua de fibras corticais $(\mathrm{Fc})$ e a saída de um traço foliar, cortando a faixa de fibras corticais. Barra $=100 \mu \mathrm{m}$. 
4 - Feixes vasculares caulinares: livres-0; agrupados em até quatro feixes desde o início do desenvolvimento-I; unidos por fibras após a diferenciação do feixe-2

Os feixes vasculares caulinares de Velloziaceae podem se apresentar livres como em Barbaceniopsis castillonii (figura 30) ou unidos por fibras como em Burlemarxia spiralis (figura 3I) e Acanthochlamys bracteata (figura 32). Encholirium scrutor (figura 33) possui feixes livres, mas Pandanus racemosus (figura 34) e Thoracocarpus bissectus (figura 35) apresentam feixes agrupados, que Tomlinson \& French (1986) chamaram de feixes compostos. Nas espécies deVelloziaceae onde os feixes vasculares apresentam-se livres, é possível encontrar feixes muito próximos uns dos outros formando grupos de dois. Estes feixes não estão unidos no momento da formação e nem se unem posteriormente pela formação de fibras entre os feixes. Considerou-se espécies com feixes livres as que apresentam mais de $90 \%$ de seus feixes vasculares livres.

A união dos feixes em Velloziaceae não se dá da mesma maneira que nas espécies do grupo externo. Em Burlemarxia spiralis, por exemplo, observa-se que, no início do desenvolvimento caulinar, os feixes apresentam-se, em sua maioria, livres (figura 36 ). Ao longo do desenvolvimento, os feixes vasculares mudam de posição no caule e se aproximam uns dos outros (figura 37 e 38). Posteriormente, as fibras associadas aos feixes vasculares se diferenciam e se lignificam (figura 39), sem formar, porém, a união de fibras observada nos caules adultos. Após a completa diferenciação e
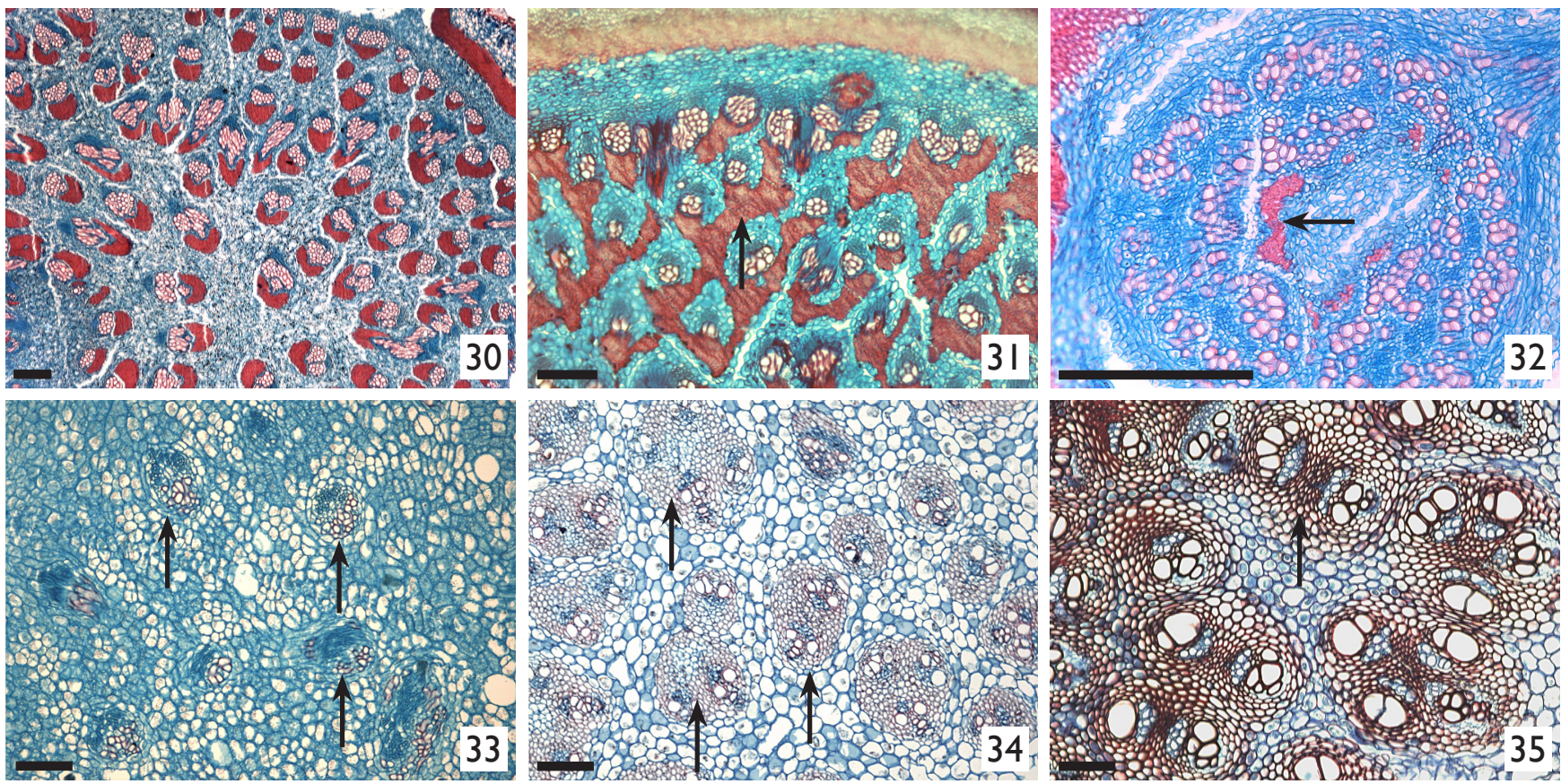

Figuras 30 a 35: Secções transversais caulinares evidenciando os feixes vasculares. 30: Feixes livres em Barbaceniopsis castillonii. 3 I e 32: Feixes vasculares unidos por fibras (setas) após sua diferenciação. 3 I: Burlemarxia spiralis. 32: Acanthochlamys bracteata. 33 a 35: Espécies representantes do grupo externo. 33: Caule de Encholirium scrutor onde os feixes são livres (setas). 34: Caule de Pandanus racemosus onde se observam feixes agrupados (setas). 35: Feixes vasculares de Thoracocarpus bissectus formando grupos (setas). Barra $=100 \mu \mathrm{m}$. 
lignificação das fibras associadas aos feixes, há deposição de parede secundária e lignificação nas células parenquimáticas localizadas entre os feixes vasculares (figura 40) unindo-os (figura 4I).

Nas espécies do grupo externo, são observados desde feixes vasculares isolados até grupos de quatro feixes. Tanto em Pandanus racemosus, quanto em
Thoracocarpus bissectus, os feixes que formam grupos estão arranjados desta maneira desde sua formação. Em Pandanus racemosus (figuras 42 a 46) já há, no início do desenvolvimento caulinar, quando apenas alguns elementos de metaxilema estão diferenciados, feixes vasculares formando grupos (figura 42). As células que posteriormente se diferenciarão em fibras e agruparão os feixes possuem menor diâmetro e já são visualiza-
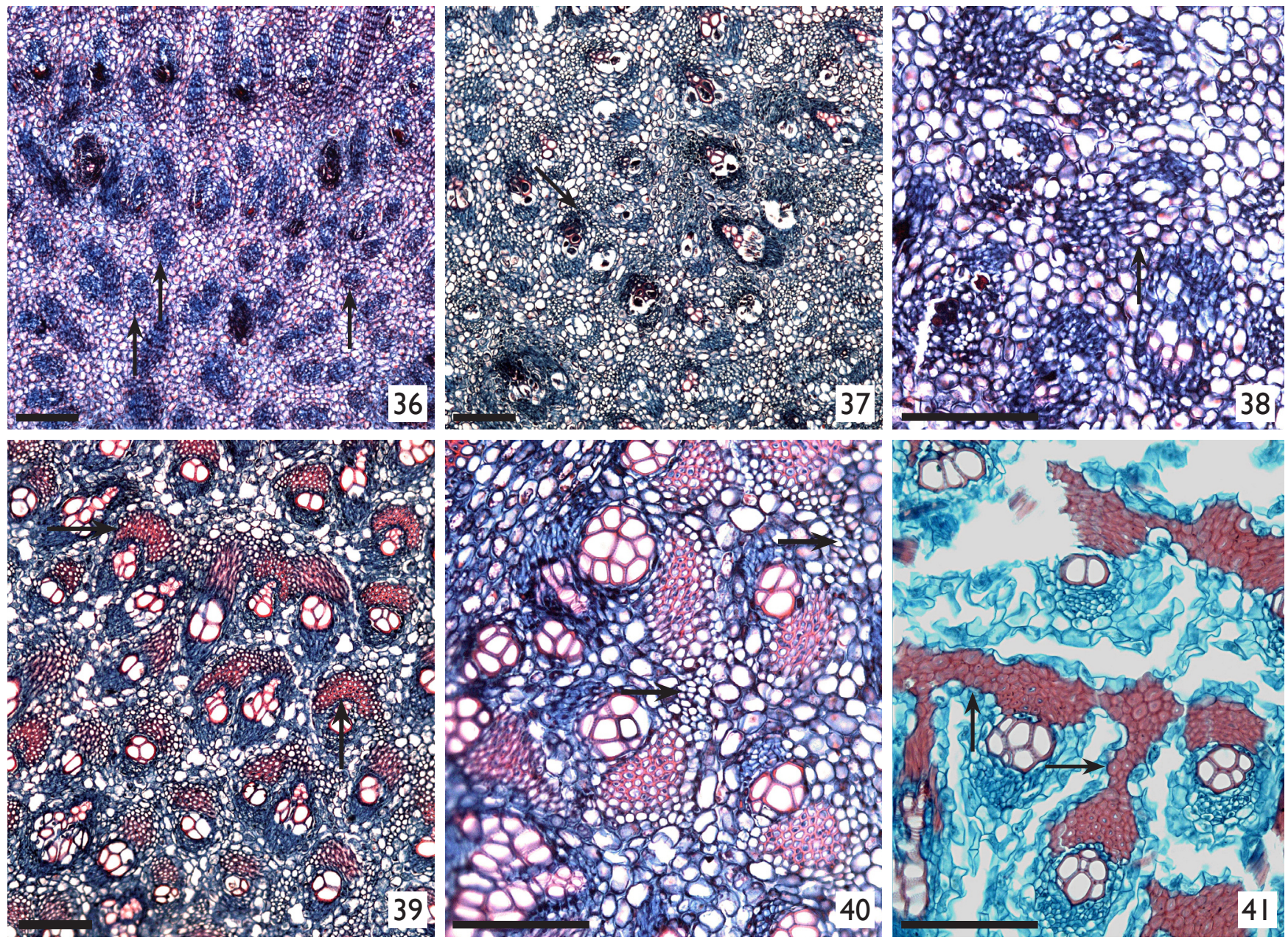

Figuras 36 a 4 I: Diferenciação dos feixes unidos por fibras em Burlemarxia spiralis. 36: Ápice caulinar onde os feixes estão iniciando a diferenciação. Nota-se que, nesta fase do desenvolvimento caulinar, os feixes são livres em sua maioria (setas). 37 e 38: Ao longo do desenvolvimento, os feixes mudam de posição aproximando-se uns dos outros (setas). 39: As fibras associadas aos feixes vasculares são as primeiras a se diferenciar. 40: Após a diferenciação dos feixes vasculares, células parenquimáticas localizadas entre os feixes, iniciam o processo de deposição de parede secunária e lignificação (setas). 4 I : Após a completa lignificação das céluas parenquimáticas observam-se os feixes unidos por fibras (setas). Barra $=100 \mu \mathrm{m}$. 

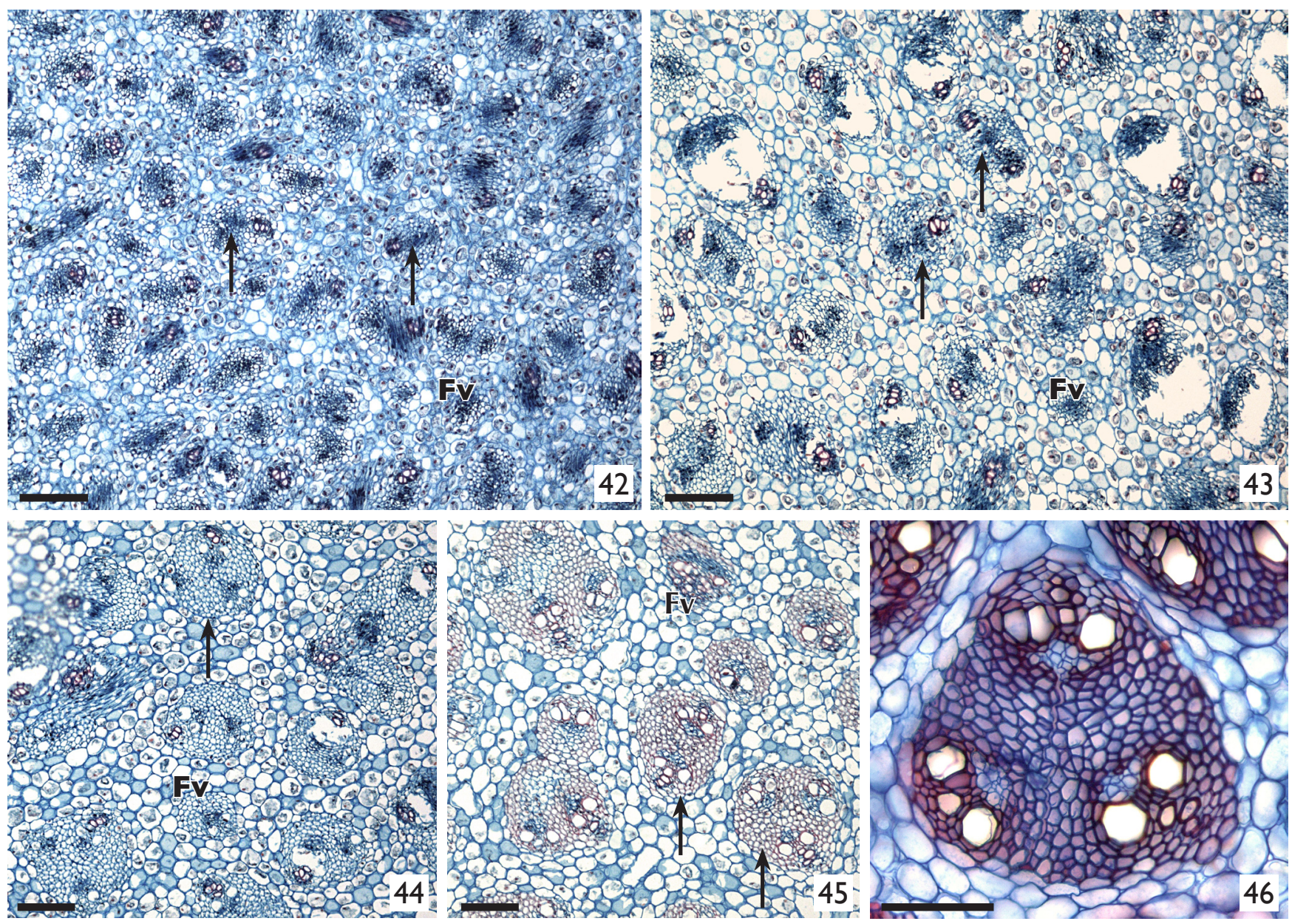

Figuras 42 a 46: Diferenciação de grupos de feixes em Pandanus racemosus. 42 a 44: Início da diferenciação dos feixes vasculares onde podem ser observados feixes livres (Fv) e grupos de feixes (setas) já determinados (setas). 44 e 45: Após a diferenciação dos elementos traqueais, as fibras associadas aos feixes iniciam a sua diferenciação. 46: Grupo de feixes vasculares em detalhe. Barra $=100 \mu \mathrm{m}$.

das desde o início do desenvolvimento (figuras 43 e 44). Os grupos de feixes se mantêm até que as fibras se diferenciem completamente (figuras 45 e 46) e permanecem assim ao longo de toda a extensão caulinar.

\section{5 - Feixe fibroso central: ausente-0; pre-} sente apenas na porção mediana do caule-I; presente ao longo de todo o caule-2

Em Velloziaceae, o centro do caule pode se apresentar lignificado (figura 47, Vellozia jolyi) ou não (figura 48, Nanuza plicata). Este agrupamento de fibras foi denominado por Menezes ( 197 I) de feixe fibroso e não está associado a feixes vasculares. Em uma espécie analisada (Barbaceniopsis castillonii), foram observadas regiões onde o feixe fibroso está ausente (figura 52) e outras onde este está presente (figura 54)

Em espécies de Vellozia como, por exemplo, $V$. hemisphaerica (figuras 49 a 5I), a diferenciação do feixe fibroso é anterior à dos feixes vasculares e o feixe fibroso central está presente em todas as porções e fases do desenvolvimento caulinar. Mesmo antes da diferenciação do feixe fibroso central, são observadas 

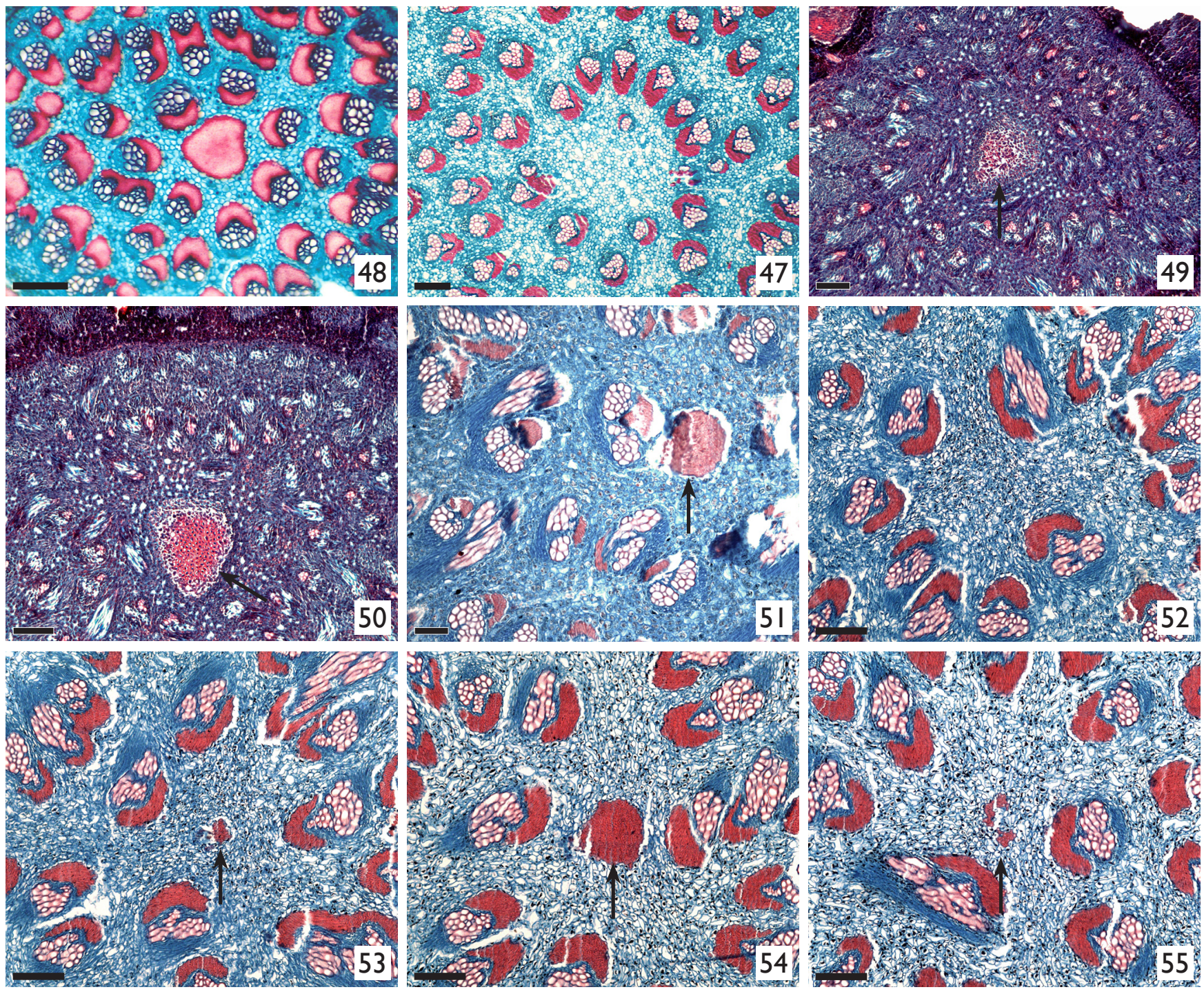

Figuras 47 a 55: Secções transversais caulinares evidenciando a ausência e presença de feixe fibroso central (Ff). 47: Presença de feixe fibroso central em Vellozia jolyi. 48: Ausência de feixe fibroso central em Nanuza plicata. Figuras 49 a 5 I: Diferenciação do feixe fibroso central em Vellozia hemisphaerica. 49 e 50: Ápice caulinar evidenciando o início da diferenciação dos feixes vasculares. Antes dos feixes vasculares estarem completamente diferenciados, inicia-se a diferenciação do feixe fibroso central (seta). $\mathbf{5}$ I: Caule adulto onde se observam os feixes vasculares e o feixe fibroso central diferenciados (seta). Esta disposição dos tecidos permanece ao longo de todo o desenvolvimento caulinar. Figuras 52 a 55: Diferenciação do feixe fibroso central em Barbaceniopsis castillonii. 52: Porção do caule onde os feixes vasculares já estão completamente diferenciados, mas ainda não se observa a presença do feixe fibroso central. 53: Na porção mediana do caule inicia-se a formação do feixe fibroso (seta). 54: Secção transversal evidenciando o feixe fibroso central completamente diferenciado (seta). 55: Após a completa diferenciação do feixe fibroso central, este começa a ser substituído por células parenquimáticas (seta) até desaparecer completamente. Figura $46-$ Barra $=200 \mu \mathrm{m}$, Figuras 47 a 54 - Barra $=100 \mu \mathrm{m}$. 
células de menor diâmetro que posteriormente formarão as fibras. Já em Barbaceniopsis castillonii, o feixe fibroso central inexiste nas porções proximal e distal do caule (figura 52), estando presente apenas na porção mediana (figura 54). O processo se inicia quando os feixes vasculares já estão completamente diferenciados e ainda não se observa o feixe fibroso (figura 52). Em um dado momento, na porção mediana do caule, é iniciada a formação do feixe fibroso (figura 53) e, logo após sua completa diferenciação (figura 54), inicia-se o processo inverso. $O$ feixe fibroso pára de ser produzido e há diminuição no número de fibras (figura 55) até o seu completo desaparecimento, quando apresenta a mesma disposição de tecidos que tinha antes da diferenciação do feixe fibroso (figura 52).

\section{6 - Fibras associadas aos feixes vasculares caulinares: ausentes-0; junto ao floema-I; junto ao xilema-2}

Todas as Velloziaceae observadas possuem feixes vasculares colaterais com fibras junto ao xilema e floema tangenciando as células do parênquima do cilindro vascular (figuras 56 a 58). No grupo externo, os feixes vasculares de Encholirium scrutor (figura 59) não possuem fibras e os de Pandanus racemosus (figura 60) e Thoracocarpus bissectus (figura 6I) apresentam fibras junto ao floema. Essa organização se mantém mesmo quando os feixes estão unidos (figuras 58 e 6l).

7 - Córtex caulinar: parenquimático com ou sem calotas de fibras-0; dividido em três

\section{porções distintas - I}

O córtex caulinar das espécies de Velloziaceae estudadas é composto por três regiões distintas: a porção externa, faixa ou cordões de fibras constituindo a porção mediana e a porção interna do córtex (figuras 16, 17,26,27).A porção externa é constituída por várias camadas de células que são parenquimáticas no início do desenvolvimento do caule (figuras I8, 23 e 24) e se lignificam ao longo da diferenciação do córtex (figura 25); após a lignificação, se assemelham à porção externa do córtex radicular. A porção mediana do caule é formada por fibras que, ou formam uma faixa contínua (figura 22), ou formam calotas (figura 16). Esta região, antes das fibras estarem completamente diferenciadas, é composta por células de menor diâmetro (figuras 24 e 25).A porção interna do córtex das Velloziaceae está descrita no caráter a seguir. No grupo externo, Encholirium scrutor (figura 2I) apresenta córtex parenquimático e Pandanus racemosus (figura 20) e Thoracocarpus bissectus apresentam córtex parenquimático com calotas de fibras dispersas no parênquima, sem dividir o córtex em regiões distintas.

\section{8 - Parede celular da porção interna do córtex caulinar: exclusivamente primária- 0; secundária- I}

Como demonstrado no caráter anterior, o córtex caulinar de todas as Velloziaceae, é composto por três regiões distintas. $O$ córtex interno pode ser formado por células parenquimáticas com parede pri- 

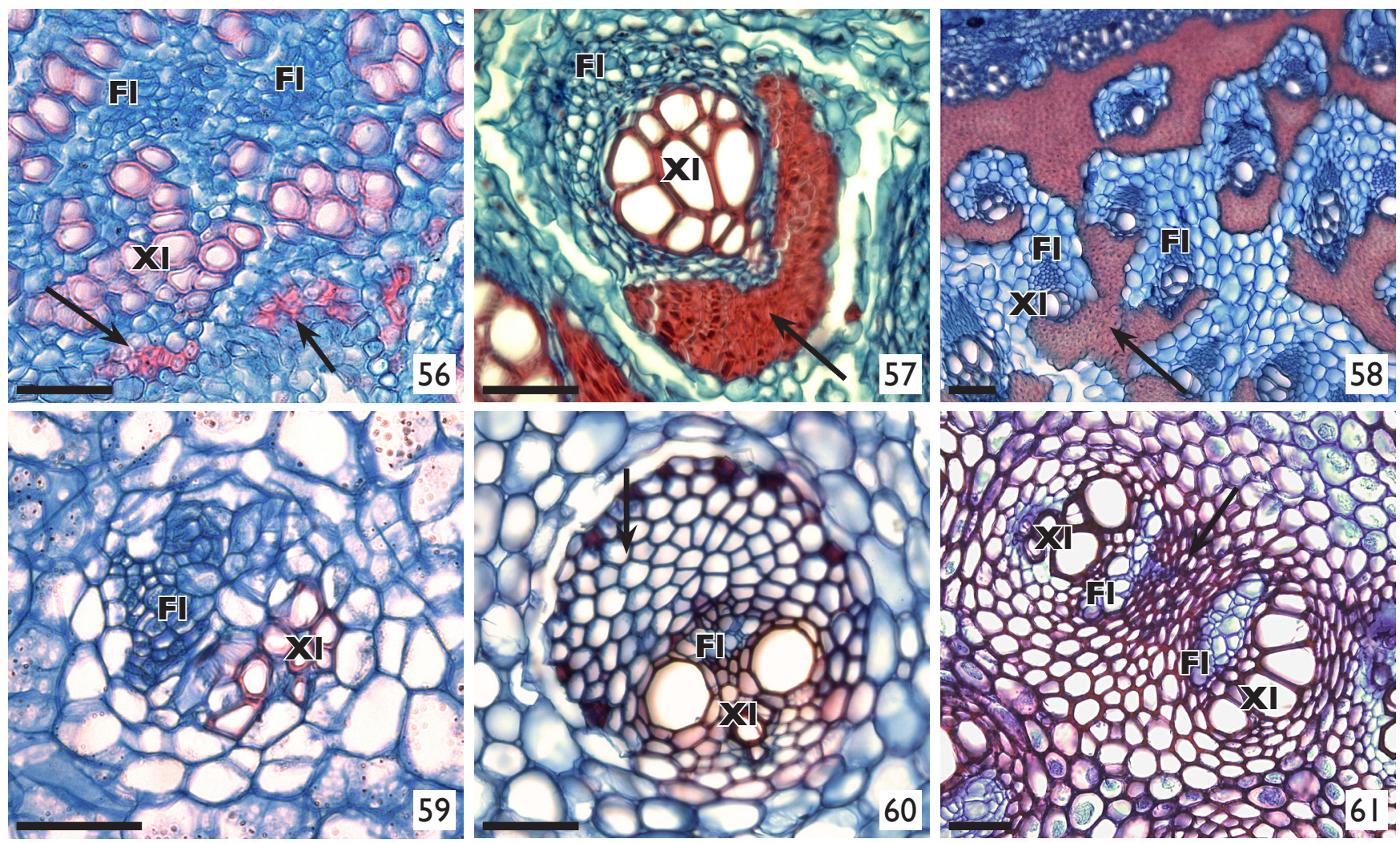

Figuras 56 a 6 I: Posição das fibras associadas aos feixes vasculares caulinares. 56: Feixes unidos em Acanthochlamys bracteata com fibras (seta) junto ao xilema (XI). Floema (FI). 57: Feixe vascular de Xerophyta dasylirioides com fibras (seta) junto ao xilema (XI). 58: Feixes unidos em Pleurostima riparia com fibras (setas) junto ao xilema (XI). 59: Ausência de fibras no feixe de Encholirium scrutor. 60: Feixe de Pandanus racemosus com fibras (seta) junto ao floema (FI). 6 I: Feixes de Thoracocarpus bissectus com fibras (seta) junto ao floema (FI). Barra $=50 \mu m$.

mária, como em Burlemarxia spiralis (figuras 24 a 27), ou pode ser composto por células parenquimáticas com parede secundária, levemente lignificadas, como em Vellozia hemisphaerica (figuras 16 e 17).Assim como ocorre na porção externa do córtex, as células, próximas ao ápice caulinar (figura 18), possuem parede primária e se lignificam posteriormente (figura 17). As espécies representantes do grupo externo possuem córtex parenquimático apenas com parede primária (figuras 20 e 21 ) com ou sem calotas de fibras, ao longo de toda a extensão do caule.
A lista de caracteres observados encontra-se na tabela II e os resultados obtidos expressos na tabela III.

A análise de parcimônia gerou uma única árvore com 295 passos. O índice de consistência (IC) foi de 0,52 e o de retenção (IR) 0,6I.A árvore resultante da análise (figura 62) evidenciou que seis caracteres aqui descritos constituem sinapomorfias para Velloziaceae incluindo Acanthochlamys bracteata, que permaneceu como espécie basal na família: fibras no córtex radicular formando uma faixa contínua, fibras associadas 
Tabela II: Caracteres analisados e sua codificação

I - Porção mediana do córtex radicular formada por uma faixa contínua de fibras

ausente (0)

presente (I)

2 - Secção transversal do caule adulto

circular $(0)$

triangular (I)

\section{3 - Fibras corticais caulinares}

ausentes ( 0 )

formando cordões (I)

formando uma faixa contínua (2)

\section{4 - Feixes vasculares caulinares}

livres (0)

em grupos de até quatro feixes desde o início do desenvolvimento (I)

unidos por fibras apos a diferenciação do feixe (2)

\section{5 - Feixe fibroso central}

ausente (0)

presente apenas na porção mediana do caule (I)

presente ao longo de todo o caule (2)

6 - Fibras associadas aos feixes vasculares caulinares

ausentes (0)

junto ao floema (I)

junto ao xilema (2)

\section{7 - Córtex caulinar}

parenquimático com ou sem calotas de fibras (0)

dividido em três porções distintas (I)

8 - Parede celular da porção interna do córtex caulinar

exclusivamente primária (0)

secundária $(I)$

Tabela III: Matriz com os estados dos caracteres observados nas espécies estudadas (ver tabela II para a codificação dos caracteres)

\begin{tabular}{|c|c|c|c|c|c|c|c|c|}
\hline ESPÉCIE & $\mathbf{I}$ & 2 & 3 & 4 & 5 & 6 & 7 & 8 \\
\hline Encholirium scrutor & 1 & 0 & 0 & 0 & 0 & 0 & 0 & 0 \\
\hline Pandanus racemosus & 0 & 0 & I & I & 0 & 1 & 0 & 0 \\
\hline Thoracocarpus bissectus & 0 & 0 & I & 1 & 0 & 1 & 0 & 0 \\
\hline Acanthochlamys bracteata & 1 & 0 & 2 & 2 & 0 & 2 & 1 & 0 \\
\hline Aylthonia umbrosa & 1 & 0 & I & 0 & 0 & 2 & I & 0 \\
\hline Barbacenia ignea & 1 & 0 & 2 & 0 & 0 & 2 & 1 & 0 \\
\hline Barbacenia reflexa & 1 & 0 & 2 & 0 & 0 & 2 & 1 & 0 \\
\hline Barbaceniopsis castillonii & 1 & 0 & I & 0 & I & 2 & 1 & 0 \\
\hline Burlemarxia spiralis & I & 0 & 2 & 2 & 0 & 2 & I & 0 \\
\hline Nanuza plicata & I & 1 & I & 0 & 0 & 2 & 1 & I \\
\hline Pleurostima longiscapa & 1 & I & 2 & 2 & 0 & 2 & 1 & 0 \\
\hline Pleurostima plantaginea & I & I & 2 & 2 & 0 & 2 & 1 & 0 \\
\hline Pleurostima riparia & 1 & 0 & 2 & 2 & 0 & 2 & 1 & 0 \\
\hline Talbotia elegans & 1 & 0 & 2 & 0 & 0 & 2 & 1 & 0 \\
\hline Vellozia abietina & 1 & 0 & 2 & 0 & 2 & 2 & I & I \\
\hline Vellozia alata & 1 & 0 & I & 0 & 2 & 2 & 1 & I \\
\hline Vellozia albiflora & 1 & 0 & 2 & 0 & 2 & 2 & I & I \\
\hline Vellozia burlemarxii & I & 1 & I & 0 & 2 & 2 & 1 & I \\
\hline Vellozia caudata & I & 0 & I & 0 & 2 & 2 & I & I \\
\hline
\end{tabular}


Tabela III: Matriz com os estados dos caracteres observados nas espécies estudadas (ver tabela II para a codificação dos caracteres) - Continuação

\begin{tabular}{lllllllll}
\hline EsPÉcIE & I & $\mathbf{2}$ & $\mathbf{3}$ & $\mathbf{4}$ & $\mathbf{5}$ & $\mathbf{6}$ & $\mathbf{7}$ & $\mathbf{8}$ \\
\hline Vellozia hemisphaerica & $\mathrm{I}$ & $\mathrm{I}$ & $\mathrm{I}$ & 0 & 2 & 2 & $\mathrm{I}$ & $\mathrm{I}$ \\
Vellozia hirsuta & $\mathrm{I}$ & 0 & $\mathrm{I}$ & 0 & 2 & 2 & $\mathrm{I}$ & $\mathrm{I}$ \\
Vellozia jolyi & $\mathrm{I}$ & 0 & $\mathrm{I}$ & 0 & 2 & 2 & $\mathrm{I}$ & $\mathrm{I}$ \\
Vellozia mínima & $\mathrm{I}$ & 0 & 2 & 0 & 2 & 2 & $\mathrm{I}$ & $\mathrm{I}$ \\
Vellozia prolifera & $\mathrm{I}$ & 0 & $\mathrm{I}$ & 0 & 2 & 2 & $\mathrm{I}$ & $\mathrm{I}$ \\
Vellozia punctulata & $\mathrm{I}$ & 0 & $\mathrm{I}$ & 0 & 2 & 2 & $\mathrm{I}$ & $\mathrm{I}$ \\
Xerophyta dasylirioides & $\mathrm{I}$ & 0 & 2 & 0 & 0 & 2 & $\mathrm{I}$ & 0 \\
Xerophyta eglandulosa & $\mathrm{I}$ & 0 & 2 & 2 & 0 & 2 & $\mathrm{I}$ & 0 \\
Xerophyta pinifolia & $\mathrm{I}$ & $\mathrm{I}$ & 2 & 2 & 0 & 2 & $\mathrm{I}$ & 0 \\
\hline
\end{tabular}

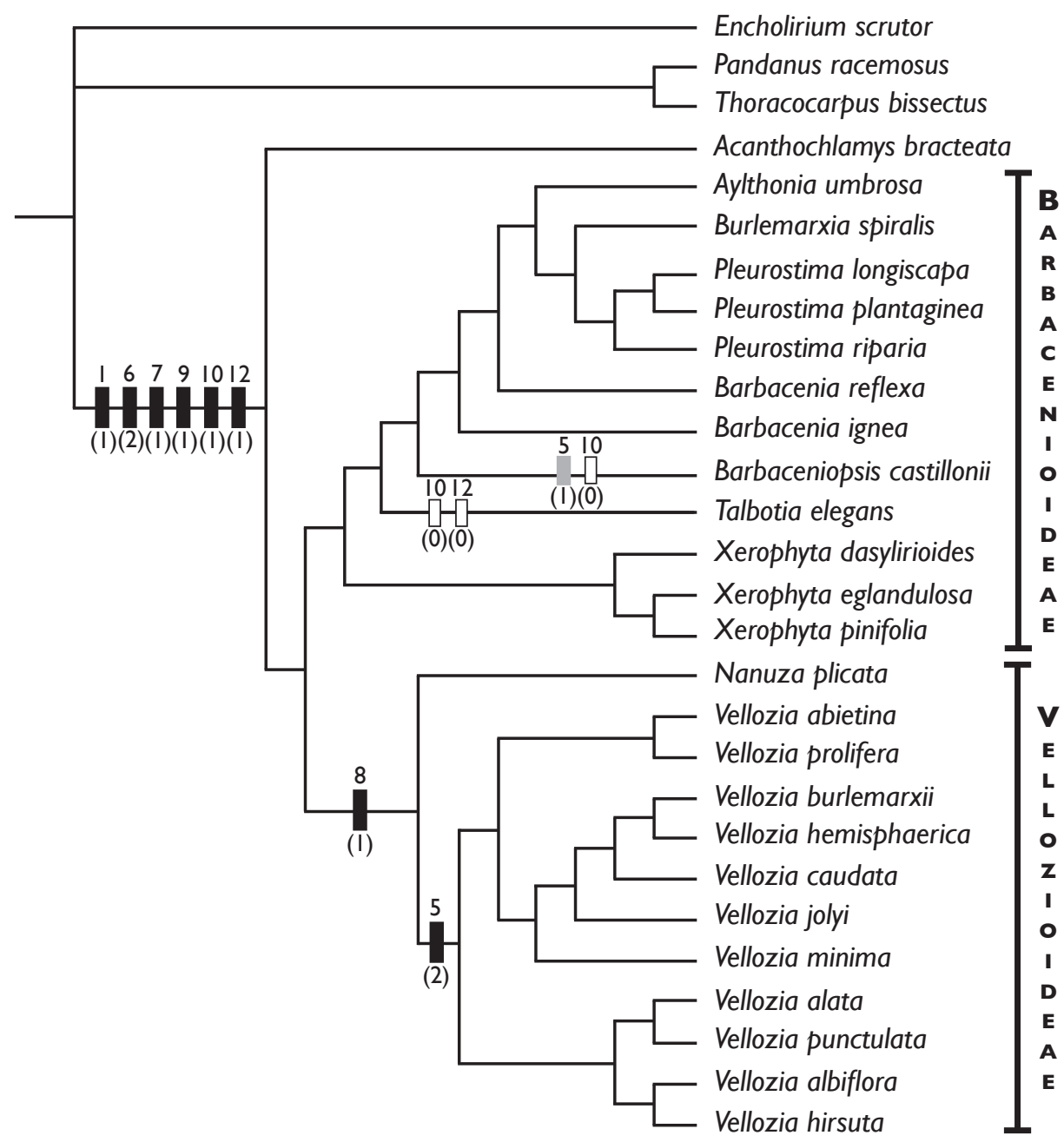

Figura 62: Árvore mais parcimoniosa resultante da análise de parcimônia, com 295 passos. As subfamílias de Velloziaceae s.s., da maneira como foram circuscritas por Smith \& Ayensu $(1974,1976)$ emergem monofiléticas e estão indicadas no cladograma. As sinapomorfias detectadas na análise estão plotadas no cladograma. 


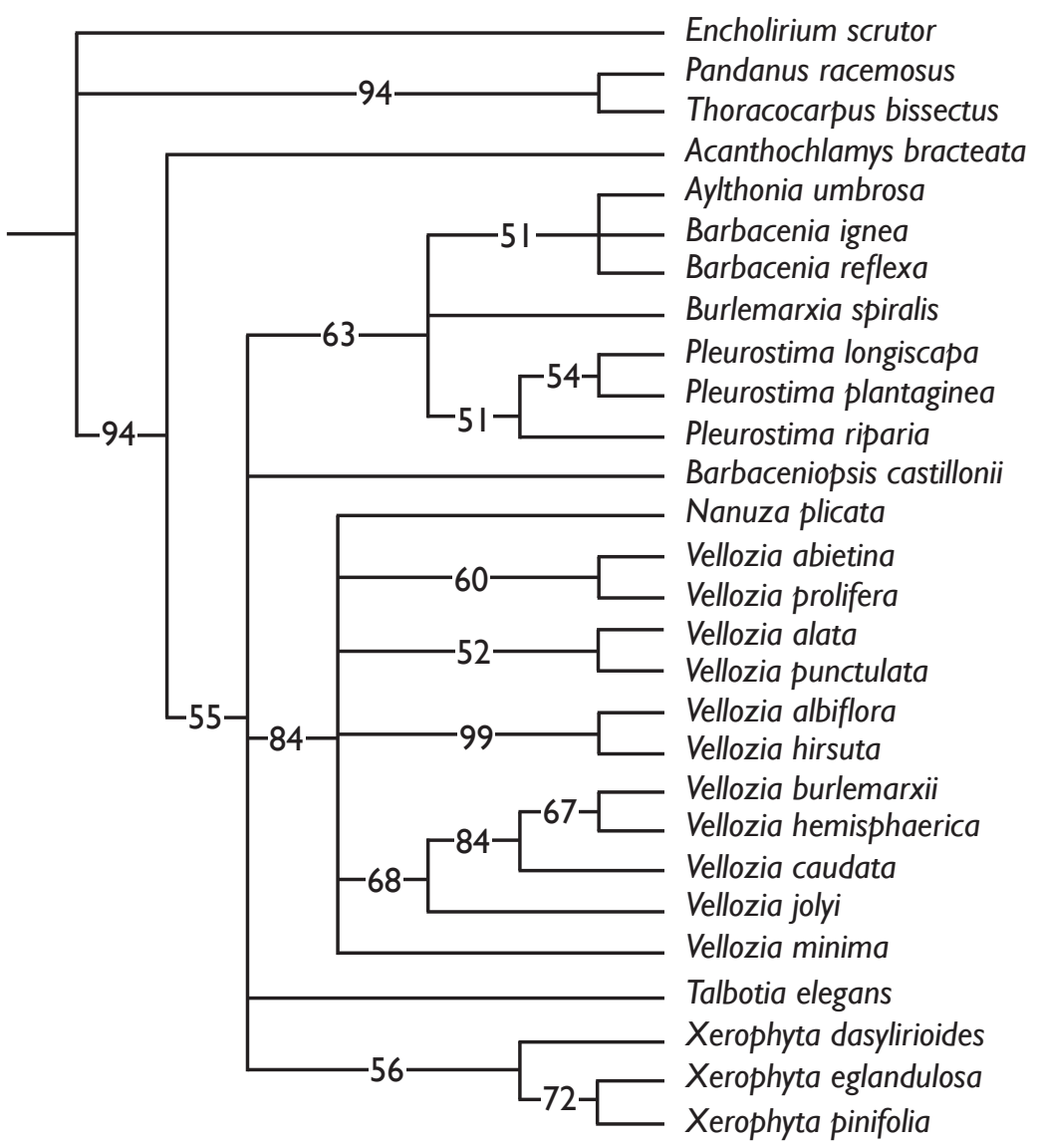

Figura 63: Cladograma de bootstrap elaborado com 10 mil replicações. mas este grupo foi colapsado na análise de bootstrap, mesmo tendo a presença de feixe fibroso central emergido como sinapomorfia do clado.

O grupo Velloziaceae s.s. (Menezes 197IA, 1980B, 1988, Smith \& Ayensu 1974, 1976) possui $55 \%$ de suporte e é formado por dois grandes grupos monofiléticos: um formado por Barbacenia s.l. Mello-Silva (2005), Barbaceniopsis e Talbotia e outro formado por Vellozia s.l. (Mello-Silva 2005). Estes dois grandes grupos correspondem à definição de Barbacenioideae e Vellozioideae, respectivamente, se Smith \& Ayensu (1974, 1976). Esta configuração possui baixo suporte e não se mantém na análise de bootstrap aos feixes vasculares caulinares junto ao xilema, córtex caulinar dividido em três porções distintas, placa de perfuração simples nos elementos de vaso radiculares, presença de elementos de vaso no caule e presença de elementos de vaso na folha. As duas últimas são sinapomorfias homoplásticas. O suporte para Velloziaceae foi de $94 \%$ na análise de bootsrap (figura 63 ).

Além das sinapomorfias para a família, a porção interna do córtex caulinar formada por células parenquimáticas com parede secundária é sinapomorfia do clado (Vellozia Nanuza), que apresentou $84 \%$ de suporte na análise de bootstrap. Vellozia s.s. (Smith \& Ayensu 1976) também emergiu como grupo monofilético, na qual Velloziaceae s.s. é formada por uma politomia envolvendo Xerophyta, Talbotia, Vellozia s.l., Barbacenia s.l. e Barbaceniopsis. Em Barbacenia s.l., apenas Pleurostima forma um grupo monofilético, mas deixa Barbacenia parafilético. Xerophyta também emerge como grupo monofilético mas com baixo suporte (56\%).

Quatro dos caracteres anatômicos do caule aqui descritos são homoplásticos. A otimização da secção transversal do caule (figura 64) aponta que o caule circular é plesiomórfico e que a forma triangular surgiu independentemente quatro vezes na família, em clados distintos. $O$ caráter fibras contínuas no córtex caulinar (figura 65) também surgiu diversas vezes na 


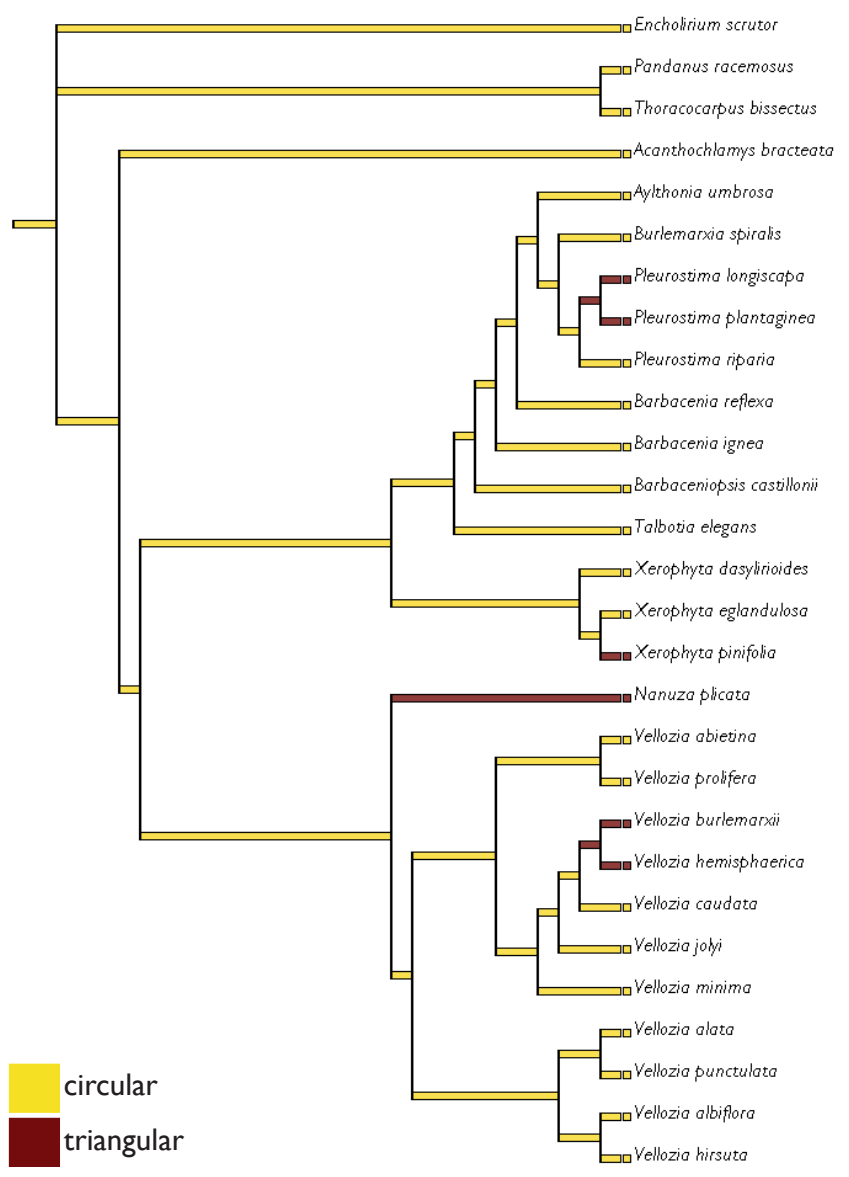

Figura 64: Otimização do caráter secção transversal do caule.

família. Em Vellozia, por exemplo, três espécies, uma de cada clado dentro do gênero, apresentam fibras contínuas no córtex. Já no clado (((Barbacenia s.l. Barbaceniopsis) Talbotia) Xerophyta), as fibras em calotas surgiram duas vezes no grupo. Quanto à disposição dos feixes vasculares caulinares (figura 66), o estado plesiomórfico é a presença de feixes vasculares livres. Feixes vasculares unidos por fibras após a diferenciação dos mesmos é, apesar de homoplástico, autapomorfia de Acanthochlamys bracteata e sinapomorfia do grupo formado por Burlemarxia e Pleurostima e do grupo formado por Xerophyta eglandulosa e X. pinifolia.

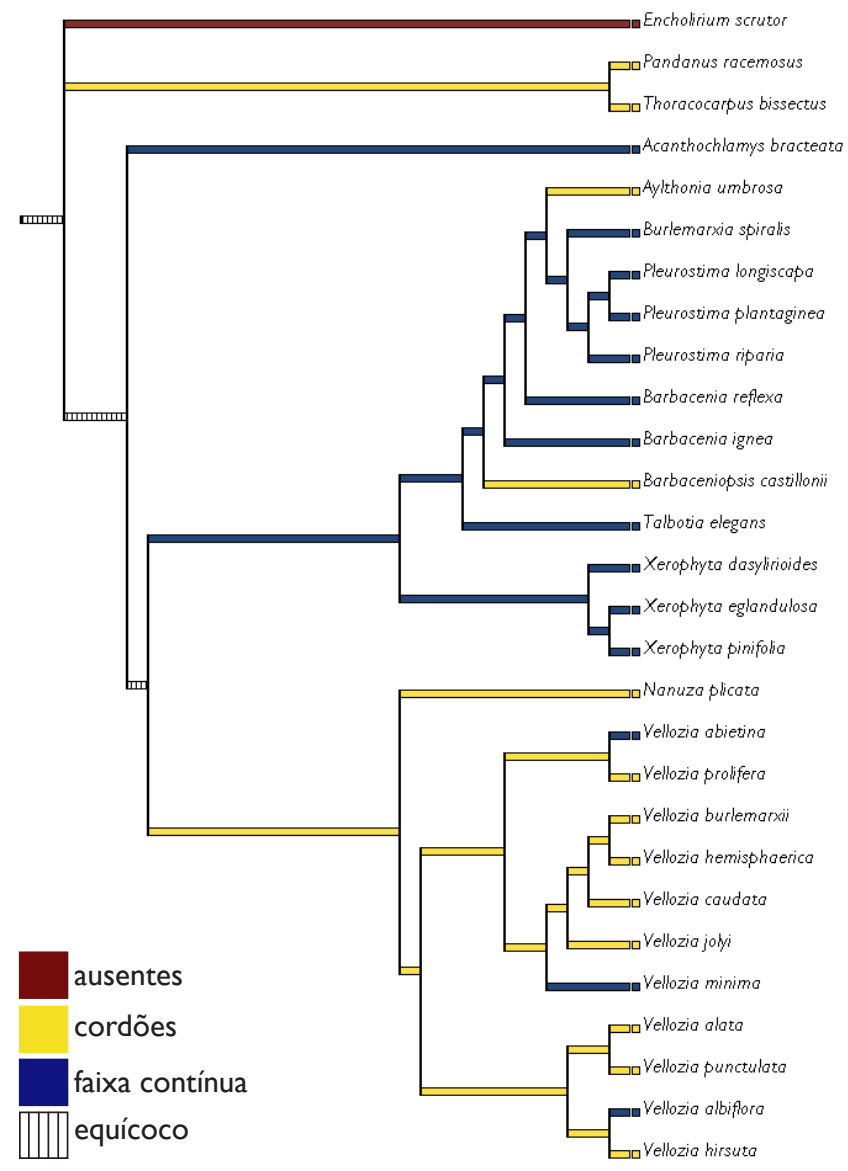

Figura 65: Otimização do caráter fibras corticais caulinares.

O caráter tipo de placa de perfuração (figura 67) também é homoplástico e o estado placa de perfuração escalariforme com muitas barras é sinapomorfia de Xerophyta e autapomorfia de Pleurostima longiscapa. Já placas de perfuração escalariforme com poucas baras surgiram independentemente em Pleurostima plantaginea e Nanuza plicata mas estas espécies são polimórficas pois também apresentam placa de perfuração simples nos elementos de vaso caulinares. Assim, o estado plesiomórfico na família é placa de perfuração simples nos elementos de vaso caulinares. 


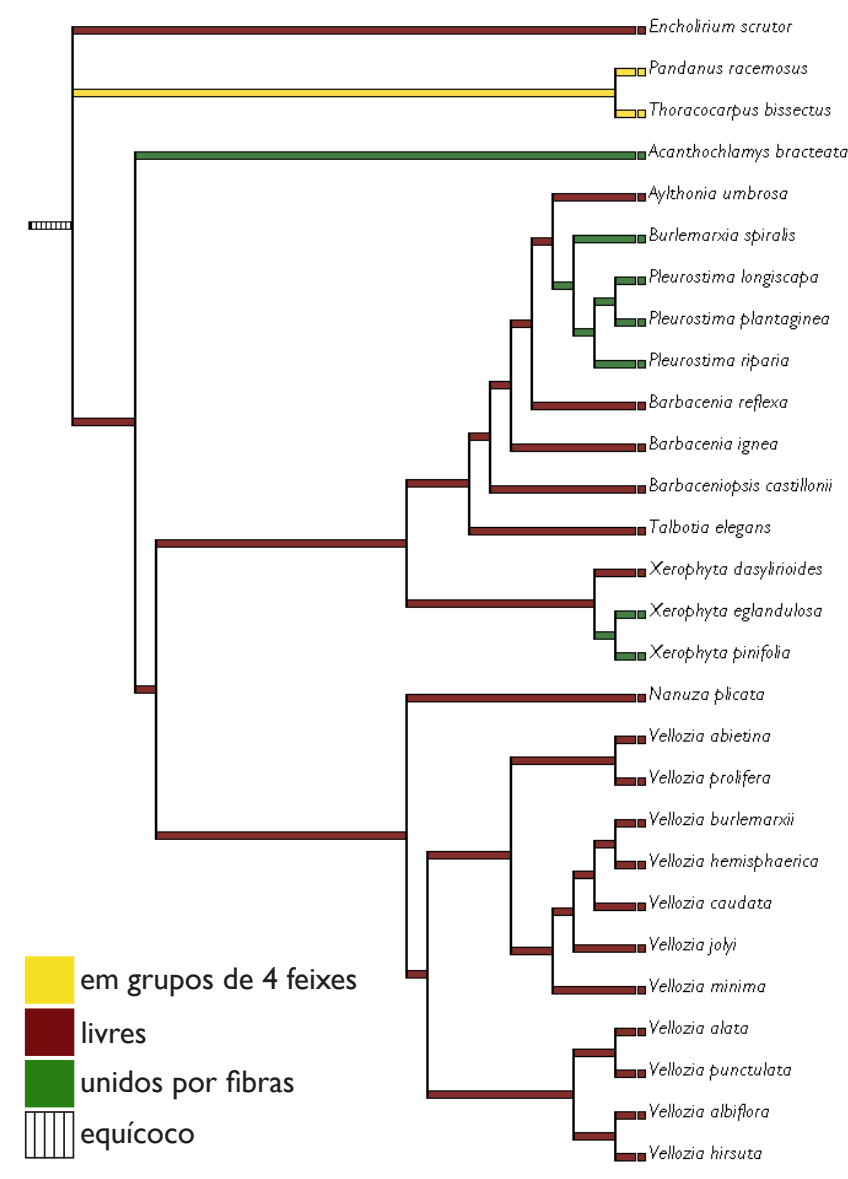

Figura 66: Otimização do caráter feixes vasculares caulinares

\section{Discussão}

A presença de uma porção externa do córtex semelhante a um velame, tanto na raiz quanto no caule pode estar relacionada ao ambiente e ao estresse hídrico a qual todas as Velloziaceae estão submetidas. Nas Orchidaceae o velame tem função de absorção e armazenamento de água, mas sua principal função, é retardar a dessecação das raízes aéreas uma vez que o vapor d'água deve passar pela hipoderme radicular e por todas as camadas do velame até evaporar por completo (Dycus 1957, Benzig, 1982). Em Velloziaceae, as raízes ocorrem junto ao caule e estes são cobertos

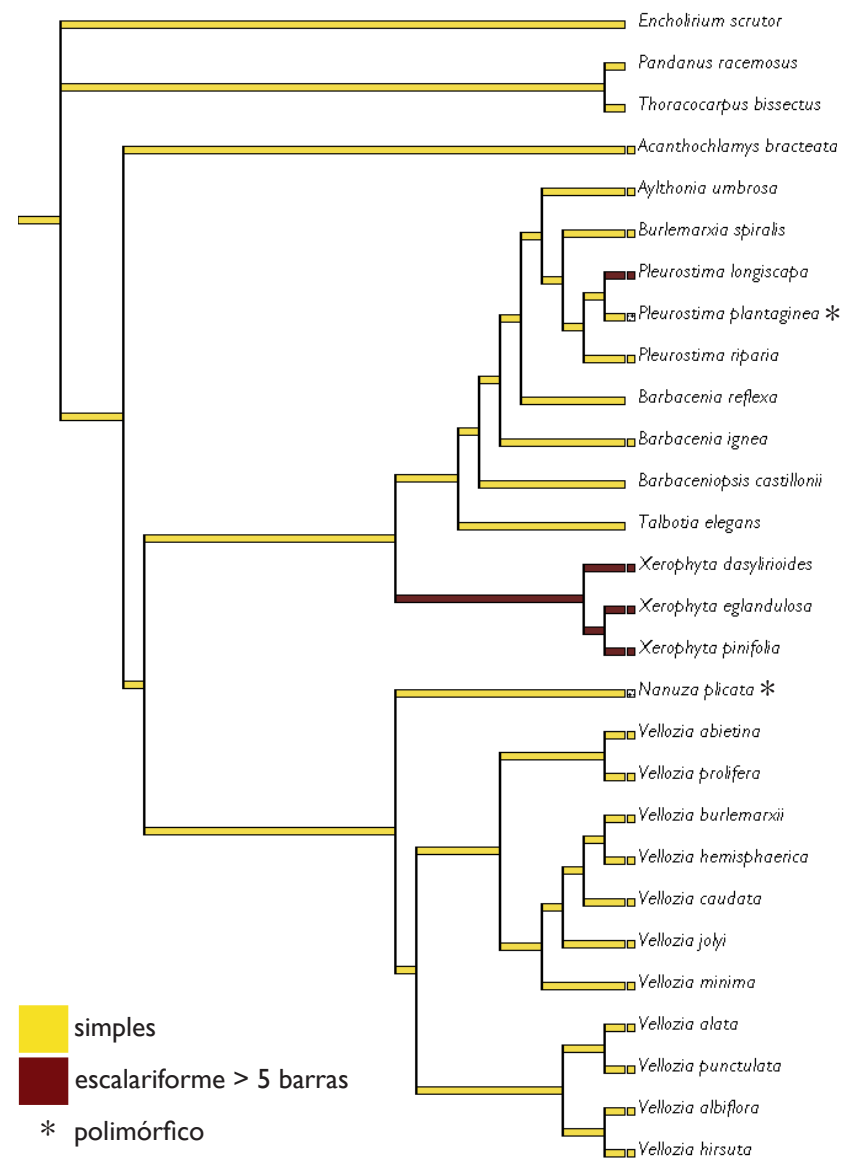

Figura 67: Otimização do caráter tipo de placa de perfuração dos elementos de vaso caulinares

pelas bainhas foliares. A água do orvalho e das chuvas é capturada entre as bainhas foliares e assim, pode ficar armazenada na porção externa dos córtex radicular e caulinar. Quando a escassez de água é grande, tanto a faixa de fibras (que ocorre na porção mediana dos córtex radicular e caulinar) quanto as células lignificadas da porção externa do córtex podem auxiliar no retardo da dessecação destes órgãos. O mesmo deve ocorrer em Encholirium scrutor uma vez que esta espécie também ocorre nos campos rupestres e está submetida às mesmas condições que as Velloziaceae. 
Como demonstrado nos resultados aqui descritos, o desenvolvimento do feixe fibroso central, que ocorre apenas na porção mediana do caule de Barbaceniopsis castillonii, não se dá da mema maneira que em Vellozia. Provavelmente a origem destas células é diferente, sendo, em Barbaceniopsis castillonii, derivadas de células parenquimáticas que se esclerificam ao longo do desenvolvimento e em Vellozia, derivadas de células precursoras de fibras que são observadas no início do desenvolvimento caulinar.Assim, o feixe fibroso central de Vellozia seria formado por fibras enquanto que o de Barbaceniopsis castillonii, de esclereídes. A mesma situação deve ocorrer em relação aos feixes vasculares unidos em Velloziaceae e em Pandanus racemosus e Thoracocarpus bissectus onde são observadas células precursoras de fibras ligando os feixes vasculares, o que não ocorre nas espécies de Velloziaceae com feixes vasculares unidos.Assim, as células responsáveis pela união dos feixes vasculares nas espécies do grupo externo podem ser fibras, enquanto que em Velloziaceae, seriam células parenquimáticas que se esclerificaram.Apenas um estudo do desenvolvimento caulinar, com secções longitudinais dos ápices caulinares, resolveria estas questões.

A posição das fibras dos feixes vasculares do caule das Velloziaceae (junto ao xilema) emergiu como uma sinapomorfia do grupo e não havia sido descrita para o caule de nenhum outro grupo de monocotiledôneas. Essa disposição das fibras foi descrita apenas para alguns feixes foliares de quatro gêneros da tribo Sisyrinchieae de Iridaceae (Rudall 1995).

A anatomia do caule e raiz de Velloziaceae é, sem dúvida, fonte importante de caracteres para análises cladísticas em Velloziaceae. Apenas duas características haviam sido apontadas como sinapomorfias de Velloziaceae incluindo Acanthochlamys bracteata que, em hipóteses filogenéticas baseadas em dados morfológicos (Mello-Silva 2005), apresentava baixo suporte, não sendo sustentada em análises de bootstrap.A primeira, "núcleo tenuinucelado" foi apontada por Stevenson \& Loconte (1995) e Mello-Silva (2005) mas foi estudada em poucos táxons da família e, por isso, foi excluída da matriz utilizada neste trabalho. A segunda, perianto violeta, foi apontada por Mello-Silva $(2000,2005)$ mas é homoplástica. $O$ fato de poucos caracteres morfológicos comuns entre A. bracteatae e Velloziaceae serem conhecidos foi utilizado por Kao \& Kubitzki (1998) para manter a família Acanthochlamydaceae. As seis sinapomorfias aqui descritas, contribuíram para os $94 \%$ de sustentação de Velloziaceae s.l. (Mello-Silva 2005) obtidos na hipótese filogenética deste trabalho e para reforçar a inclusão de A. bracteata na família.

Apesar da presença de elementos de vaso no caule e na folha terem emergido como sinapomorfias da família, este fato se deve, provavelmente, à escolha das espécies representantes do grupo externo uma vez que Cheadle (1942) descreveu a presença de elementos de vaso no caule e folha de espécies de Cyclanthaceae e Pandanaceae.

A árvore mais parcimoniosa obtida neste estudo é a única das hipóteses filogenéticas já realiadas para a família (Menezes et al. 1994, Mello-Silva 2000, 2005, Behnke et al. 2000, Salatino et al. 200 I) que sus- 
tenta a delimitação das duas subfamílias (Barbacenioideae e Vellozioideae) descritas para Velloziaceae s.s. proposta por Smith \& Ayensu (1974, 1976).

\section{O clado (Nanuza Vellozia) que aparecia colap-} sado na análise de bootstrap de Mello-Silva (2005), apresentou $84 \%$ de sustentação fato que, possivelmente, se deve ao caráter presença de parede celular secundária na porção interna do córtex caulinar, única sinapomorfia não homoplástica do grupo.

O cladograma obtido com a adição dos caracteres anatômicos da raiz e do caule não sustenta a delimitação de Xerophyta proposta por Mello-Silva (2005), uma vez que Barbaceniopsis castillonii não emerge como grupo irmão das demais Xerophyta, mas, é grupo irmão de Barbacenia s.l. É possível que o caráter fibras corticais caulinares formando uma faixa contínua tenha contribuído para este posicionamento uma vez que, é sinapomorfia de Xerophyta e, em Barbaceniopsis, as fibras estão dispostas em calotas. $\mathrm{Na}$ análise de bootstrap, tanto Xerophyta quanto Barbaceniopsis fazem parte da politomia basal de Velloziaceae s.s. e, assim, o estudo de um maior número de espécies do Barbaceniopsis e a análise combinada que está sendo elaborada para a família (Mello-Silva et al. in prep.) contribuirão para uma melhor compreensão das relações entre estes dois gêneros.

A presença de feixe fibroso central ao longo de todo o desenvolvimento da planta é sinapomorfia de Vellozia s.s. (Smith \& Ayensu 1976), mas não contribuiu para uma melhor sustentação do clado, que colapsou na análise de bootstrap. Já a presença de feixe fibroso central apenas na região mediana do caule é autapomorfia de Barbaceniopsis, sendo necessária a análise do desenvolvimento caulinar das outras duas espécies do gênero para confirmar se este estado de caráter constitui uma sinapomorfia do gênero.

Quanto aos caracteres do xilema, descritos no capítulo I, a presença de placa de perfuração simples na raiz e de elementos de vaso no caule emergiram como sinapomorfias de Velloziaceae.A presença de elementos de vaso no caule sofreu, porem, duas reversões - em Barbaceniopsis castillonii e Talbotia elegans. $\mathrm{Na}$ folha, o estado plesiomórfico é, como no caule, a presença de elementos de vaso, sendo que apenas Talbotia elegans apresenta ausência deste tipo de elemento traqueal na folha. Assim, a ausência de elementos de vaso, tanto no caule, quanto na folha, é um estado apomórfico em Velloziaceae e não primitivo, como proposto por Menezes et al. (1990). O estado plesiomórfico do caráter tipo de placa de perfuração nos elementos de vaso caulinares é placa de perfuração simples, sendo que a placa de perfuração escalariforme surgiu duas vezes na família, nas espécies de Xerophyta e em Pleurostima longiscapa.

Caracteres anatômicos caulinares e radiculares mostraram-se importantes para a interpretação das relações evolutivas de Velloziaceae e podem contribuir para uma melhor compreensão das relações entre as famílias de Pandanales que é composta por famílias agrupadas com base exclusivamente em caracteres moleculares e de difícil posicionamento filogenético (Rudall \& Bateman 2006). 


\section{ReferênCIAS Bibliográficas}

Alves, R.J.V. 2002.Two new species of Nanuza (Velloziaceae) from Brazil. Novon 12: 12-17.

Ayensu, E. S. 1968. The anatomy of Barbaceniopsis, a new genus recently described in the Velloziaceae. American Journal of Botany 55(4): 399-405.

AYENSU, E. S. 1969A. The identity of Vellozia uiapanensis. Anatomical evidence. Memoirs of the New York Botanical Garden 18(2): 291-298.

Ayensu, E. S.. 1969B. Leaf-anatomy and systematics of Old World Velloziaceae. Kew Bulletin 23: 315-335.

AYENSU, E. S. 1974. Leaf anatomy and systematics of new WorldVelloziaceae. Smithsonian Contributions to Botany 15: I-75.

Behnke, H.-D., Treutlenin, J., Wink, M., Kramer, K., Schneider, C. \& KAO, P. C. 2000. Systematics and evolution of Velloziaceae, with special reference to sieve-element plastids and rbcL sequence data. Botanical journal of the Linnean Society I3493-I 29.

Benzig, D. H., Ott, D.W., Friedman, W. E. 1982. Roots of Sobralia macrantha (Orchidaceae): structure and function of the velamen-exodermis complex.American Journal of Botany 69 (4): 608-6I4.

BUKATSCH, F. 1972. Bemerkungen zur doppelfärbung astrablau-safranin. Mikrokosmos 6I(8): 255.

Chase, M.W., Soltis, D. E., Olmstead, R. G., Morgan, D., Les, D. H., Mishler, B. D., Duvall, M. R., Price, R. A. Hills, H. G., Qiv,Y.-L., Kron, K.A., Rettig, J. D., Manhart, J. R., Sytsma, K. J., Michaels, H. J., Kress, W. J., Karol, K. G., Clark, W. D., Hedrén, M., Gau, B. S., Jansen, R. K., Kim, K.-J., Wimpee, C. F., Smith, J. F., Furnier, G. R., Strauss, S. H., Xiang, Q.Y., Plunkett, G. M., Soltis, P. S., Swensen, S. M., Williams, S. E., Gadek, P. A., Quinn, C. J., Eguiarte, L. E., Golenberg, E., Learn Jr., G. H., Graham, S. W., Barrett, S. C. H., Dayanandan, S., Albert, V. A. 1993. Phylogenetics of seed plants: an analysis of nucleotide sequences from the plastid gene rbcL. Annals of the Missouri Botanical Garden 80: 529-580.

Chase, M. W., Stevenson, D. W., Wilkin, P., Rudall, P. J. 1995. Monocot systematics: a combined analysis. In: Monocotyledons: systematic and evolution (P. J. Rudall, Cribb, P.J., Cutler, D. F., Humphries, C.J., ed). Royal Botanic Gardens, Kew, p. 685-730.

Chase, M. W., Fay, M. F., Devey, D. S., Maurin, O., Rønsted, N., Davies, J., Pillon, Y., Petersen, G., Seberg, O., TamuRa, M. N., Asmussen, C. B., Hilu, K., Borsch, T., Davis, J. I., Stevenson, D.W., Pires, C., Givnish, T. J., Sytsma, K. J., McPherson, M. M., Graham, S.W., Ral, H. S. 2006. Multigene analyses of monocots relationships: a summary. In: (Eds.) J. T. Columbus, E. A. Friar, J. M. Porter, L. M. Prince, M. G. Simpson. Monocots: comparative biology and evolution. Claremond California: Rancho Santa Ana Botanic Garden. Aliso (I): 62-74.

Cheadle,V. I. 1942. The occurence and type of vessels in the varios organs of the plant in the Monocotyledonae. American Journal of Botany 29: 44I-450.

Dycus, A. M., KNUDSON, L. 1957. The role of the velamen of the aerial roots of Orchids. Botanical Gazette II 9 (2): 78-87.

EverT, R. F. 2006. Esau's plant anatomy. Meristems, cells and tissues of the plant body - their structure, function and development. Madison, Wiley-Interscience.

FARRIS, J. S. 1982. Outgroups and pacimony. Systematic Zoology $31: 328-334$

Felsenstein, J. 1985. Confidence-limits on phylogenies - an approach using the bootstrap. Evolution 39: 783-79I.

Ferrarezzi, H., Marques, A. C. 1997. Análise cladística numérica e recursos computacionais. In: Amorin, D. S. (ed.). Elementos básicos de sistemática filogenética, 163186. $2^{\mathrm{a}}$ ed. Holos Editora e Sociedade Brasileira de 
Entomologia, Ribeirão Preto.

GerLaCh, D. 1984. Botanische Mikrotechnik. Georg Thieme Verlag, Stuttgart.

Holm, T. 1895. Noteworthy anatomical and physiological researches. Anatomy of Vellozieae. Botanical Gazette 20(3): I I I-II5.

KAO, P. C., KUBITZKI, K. 1998.Acanthochlamydaceae. In: Kubitzki, K. (ed.). The families and genera of vascular plants, 3: 55-58. Berlin, Springer.

Maddison, D. R., Maddison, W. 2000. MacClade: analysis of phylogeny and character evolutions. Version 4.0. Sinauer Associates Inc. Sunderland.

Mcpherson, G.,Van Der Werff, H., Keating, R. C. I 997.A new species of Xerophyta (Velloziaceae) from Madagascar. Novon 7: 387-394.

Mello-Silva, R. 199IA. The infra-familial taxonomy circumscription of the Velloziaceae. A historical and critical analysis. Taxon 40: 45-5I.

Mello-Silva, R. I 99 I B.A new specie of Vellozia from the espinhaço range Brazil, with some considerations on the section Xerophytoides. Kew Bulletin 46(2): 321-326.

Mello-Silva, R. 2000. Partial cladistic analysis of Vellozia and characters for the phylogeny of Velloziaceae. In: Monocots Systematic and Evolution (K. L.Wilson, Morrison, D.A., ed). CSIRO, Melbourne, p. 505-522.

Mello-Silva, R. 2005. Morphological analysis, phylogenies and classification in Velloziaceae. Botanical Journal of the Linnean Society I48: I57-I73.

Mello-Silva, R. \& Menezes, N. L. 1999. Two new brazilian Velloziaceae, Vellozia auriculata and Vellozia gigantea, and a key to the related dracenoid species of Vellozia. Novon 9(4): 536-54I.

Mello-Silva, R., Santos, D.Y.A.C., Salatino, M.L.F., Mota, L.B., Cattal, M.B., Sasaki, D., Rocini, C., Rodrigues, C.D.N., Zarrei, M., Chase, M.W. In prep. A combined analysis of Velloziaceae.

Menezes, N. L. 197I A. New taxa and new combinations in
Velloziaceae. Ciência e Cultura 23: 421-422.

Menezes, N. L. 197/B. Traqueídes de transfusão no gênero Vellozia Vand. Ciência e Cultura 23: 389-409.

Menezes, N. L. 1973. Natureza dos apêndices petalóides em Barbacenioideae (Velloziaceae). Boletim de Zoologia e Biologia Marinha, N. S. 30: 7I3-755.

Menezes, N. L. 1975. Presença de traqueídes de transfusão e bainha mestomática em Barbacenioideae (Velloziaceae). Boletim de Botânica da Universidade de São Paulo 3: 29-60.

MeneZes, N. L. 1976. Megasporogênese, megagametogênese e embriogênese em Velloziaceae. Boletim de Botânica da Universidade de São Paulo 4: 4 I-60.

Menezes, N. L. 1980A. Evolution in Velloziaceae, with special reference to androecial characters. Linnean Society Simposium Series 8: I17-138.

Menezes, N. L. 1980B. Nova espécie e novas combinações no gênero Pleurostima Raf. (Velloziaceae). Boletim de Botânica da Universidade de São Paulo 8: 65-69.

Menezes, N. L. 1988. Evolution of the anther in the family Velloziaceae. Boletim de Botânica da Universidade de são Paulo 10: 33-4l.

Menezes, N. L., Giuliettı, A. M. 1986. Campos Rupestres. Ciência Hoje 5 (25): 38-44.

Menezes, N. L., Semir, J. 1990. New considerations regarding the corona in the Velloziaceae. Annals of the Missouri Botanical Garden 77(3): 539-544.

Menezes, N. L., Semir, J. I99I. Burlemarxia, a new genus of Velloziaceae. Taxon 40: 413-426.

Menezes, N. L., Castro, N. M. 2000. Células piramidais apicais dos tegumentos do óvulo em Velloziaceae e suas relações filogenéticas. Boletim do Museu de Biologia Mello Leitão I I/I2: 49-56.

Menezes, N. L., Kameyama, C., Pires, F. R. S.,Assis, M. C., Bianchi, R. S., SouzA, V. C. 1990. O xilema de Velloziaceae e as relações entre os diferentes gêneros da família. XLI Congresso Nacional de Botânica, Universidade Federal do Ceará: 180. 
Menezes, N. L., Mello-Silva, R., Mayo, S. J. 1994. A cladistic analysis of the Velloziaceae. Kew Bulletin 49(I): 7I-92.

Nixon, C. K., Carpenter, J. M. N. 1993. On outgroups. Cladistic 9: 4I3-426.

POREMBSKI, S., BARTHLOTT,W. 1995. On the occurrence of a velamen radicum in Cyperaceae and Velloziaceae. Nordic Journal of Botany I5(6): 625-629.

PitA, P. B., Menezes, N. L. 2002. Anatomia da raiz de espécies de Dyckia Schult. f. e Encholirium Mart. ex Schult. \& Schult. f. (Bromeliaceae, Pitcairnioideae) da Serra do Cipó (Minas Gerais, Brasil), com especial referência ao velame. Revista Brasileira de Botânica 25 (I): 25-34.

RUDALL, P. J. 1995. Anatomy of the monocotyledons. VIII. Iridaceae. Oxford University Press.

Rudall, P. J., Bateman, R. M. 2006. Morphological phylogenetic analysis of Pandanales: testing contrasting hypotesis of flora evolution. Systematic Botany 3 I (2): 223-238.

SMith, L. B., Ayensu, E. S. 1974. Classification of old world Velloziaceae. Kew Bulletin 29(I): I8I-205.

SMITH, L. B.,AYENSU, E. S. 1976.A revision of American Velloziaceae. Smithsonian Contributions to Botany 30: I-172.
Salatino,A., Salatino, M. L. F., Mello-Silva, R., Sluys, M.A. 200 I. Phylogenetic inference in Velloziaceae using cloroplast trnL-F sequences. Systematic Botany 26: 92-103.

SMITH, L. B. 1962. A synopsis of the American Velloziaceae. Contributions from the United States National Herbarium 35:25|-292.

Stevenson, D.W., Loconte, H. 1995. Cladistic analysis of monocot families. In: Rudall, P. J., Cribb, P. J., Cutler, D. F., Humphries, C. J. (Eds.) Monocotyledons: Systematics and evolution. Royal Botanic Gardens, Kew. 543-578

SWOFORD, D. L. 2002. PAUP*. Phylogenetic analysis using parcimony (*and othe methods). Version 4.0bl0. Sinauer Associates. Sunderland.

TomLINSON, P. B. 1969. Anatomy of the monocotyledons. III. Commelinales-Zingiberales. Oxford, Clarendon Press.

Tomlinson, P. B., French, J. C. 1986. Compound vascular bundles in Monocotyledonous stems: construction and significance. Kew Bulletin 4I (3): 56I-574.

Warming, M. E. 1893. Note sur la biologie et l'anatomie de la feuille des Vellosiacées. Overs. K. Danske Vidensk. Selsck Forh: 57-100. 


\section{Considerações Finais}

Diante dos resultados apresentados é possível destacar os aspectos mais relevantes deste trabalho que foi importante por:

谟 Estabelecer, pela primeira vez, a diversidade dos elementos traqueais de Velloziaceae.

Determinar caracteres do xilema que podem ser utilizados em análises cladísticas de Velloziaceae e aplicados à outros grupos de monocotiledôneas.

苔 Redelimitar o caráter presença de elementos de vaso em folhas de Velloziaceae, mal estabelecido em filogenias anteriores.

* Contribuir para um melhor conhecimento da anatomia radicular e caulinar de Velloziaceae, pouco descrita na literatura.

* Esclarecer que a porção externa do córtex radicular de Velloziaceae não constitui um velame.

Identificar que as fibras associadas aos feixes vasculares caulinares localizam-se junto ao xilema, característica observada pela primeira vez dentre as monocotiledôneas.

谟 Identificar quatro novas sinapomorfias não homoplásticas que sustentam a inclusão de Acanthochlamys bracteata em Velloziaceae, melhorando a sustentação da família.

苍 Identificar uma sinapomorfia não homoplástica para o clado Vellozia sensu Mello-Silva

त Determinar novos caracteres anatômicos que serão incorporados à análise de evidência total de Velloziaceae que está sendo elaborada. 